\title{
Sexual Violence as an Afterthought: Securing Justice for Sexual Violence Victims in the International Criminal Tribunal for Rwanda
}

By

\section{Kellie-Sue Hoy}

A Thesis Submitted to the Victoria University of Wellington in Fulfilment of the Requirements for the Degree of Master of Arts in Criminology

Victoria University of Wellington (2013) 


\begin{abstract}
Using Nancy Fraser's (2007a) tripartite model of justice as a theoretical backdrop, this thesis critically evaluates the United Nation's (UN) International Criminal Tribunal for Rwanda (ICTR), in relation to how this Tribunal has both secured and limited opportunities to 'do' justice for sexual violence (SV) victims. This thesis applies a gendered approach to Fraser's model, and considers how justice has been secured by women, based on principles of recognition, redistribution and representation.

Using documentary methods, the thesis analyses ICTR cases concerning SV, to determine how this Tribunal has responded to SV committed against women and girls throughout the Rwandan genocide. This thesis demonstrates that, while the Tribunal has secured some level of justice for SV victims by successfully indicting, prosecuting and punishing some individuals responsible for $\mathrm{SV}$, these crimes have been constructed and responded to in ad hoc and skewed ways. The analysis shows that crimes of SV, as well as its victims, are underrepresented in the ICTR. It also demonstrates that where SV has been addressed, the institutional culture and framework of this Tribunal has marginalised the voice of women, and allowed for discriminatory and insensitive court practices to permeate judicial proceedings. SV victims, who continue to struggle with redistributive injustices, have been negatively impacted by these ICTR practices.
\end{abstract}




\section{Acknowledgements}

Although my research never took me to Rwanda, I hope that my thesis has given women and girls who suffered SV throughout the Rwandan genocide some recognition. Too often, violence against women and girls slips under the radar of international initiatives that address crimes of IHL. I hope that the scholarship within this area continues to thrive. More so, I hope that international institutions, like the UN, continue to improve in their efforts to address SV in a way that is consistent with the needs of those so deeply affected.

Writing this thesis has been an immensely challenging task that would not have been possible without the support, encouragement and guidance from my amazing Supervisor- Elizabeth Stanley. Lizzy you've pushed me when I've felt like giving up, and taught me that there's always ways to make things better. Your knowledge and compassion has reminded me why I have spent the past five years studying here at Victoria. Words cannot express how thankful I am for everything.

My editors- Jared Walton, Cara Gledhill, Tom Lynskey, Garrity Hill, Sam Keene and Janie Houghton - thank-you for helping me perfect my work. I am really grateful for your help. Thank-you to amazing friends, particularly Jared Walton, Cara Gledhill, Lara Bell, Garrity Hill, Gina Papageorgio, Ingrid Dixon, Haleigh Pert, Alysha Jones and Michelle Cook.

Mum and Dad - you've always pushed me to go on new and exciting intellectual journeys, reminding me that nothing is impossible. Your love and guidance has helped me make all the right decisions in life. My little blistings - Jade and Jak - thank-you for always being there for me. To Nanna - thank-you for years of encouragement and support throughout my schooling endeavours. To the Smith's - thank-you for being my designated NZ family. Weekly dinners and intellectual wind ups at the Smith house has made this journey easier. Without you guys, life would be very dull.

Most of all, to Brendan - you've been there for me through the good, bad and worse. To say I stress a lot would be an understatement - thank-you for keeping the tears away AND for keeping me sane. I couldn't have done this without you. 


\section{Table of Contents}

Abstract...............................................................................ii

Acknowledgements....................................................................v

Table of Abbreviations..........................................................ix

Chapter One: Introduction....................................................1

Legal Justice for Sexual Violence Victims....................................6

A Feminist Theoretical Approach........................................... 8

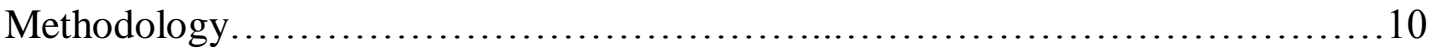

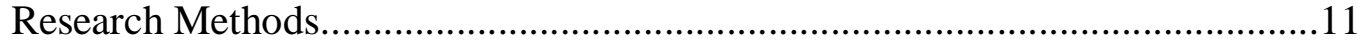

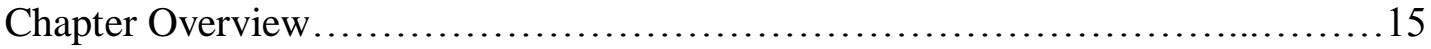

Chapter Two: Justice for Conflict-Related Sexual Violence Victims................17

The Causes and Functions of Sexual Violence in Conflict...........................18

The Consequences of Sexual Violence in Conflict..............................23

Sexual Violence Victims and their Pursuit for Justice..........................25

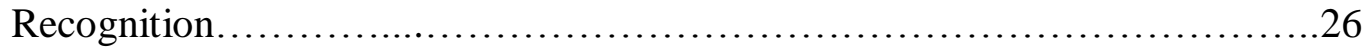

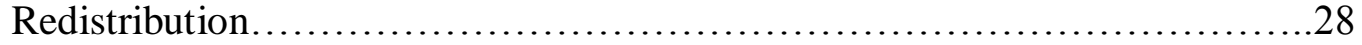

Representation....................................................... 30

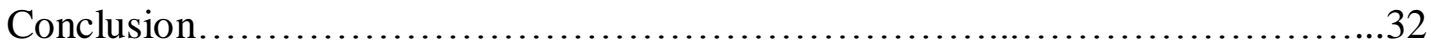

Chapter Three: Securing Justice for Sexual Violence Victims in International

Criminal Tribunals.................................................................33

Providing Recognition...................................................... 34

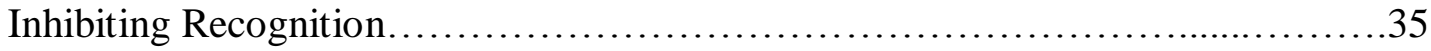

Providing Redistribution....................................................

Inhibiting Redistribution................................................. 41

Promoting and Inhibiting Representation.....................................43

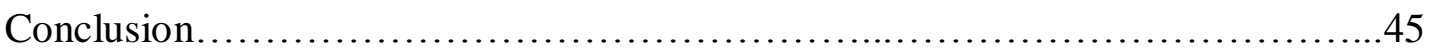

Chapter Four: Responding to Sexual Violence in the United Nation's International

Criminal Tribunal for Rwanda................................................47

Securing Recognition for Sexual Violence Victims in the ICTR.................48

Limiting Recognition for Sexual Violence in the ICTR...........................51

Institutional Incapacities............................................5

Problems with the Institutional Framework ................................57

Problems with Participation.............................................69 
Securing and Limiting Redistributive Justice ................................72

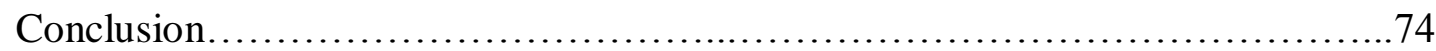

Chapter Five: Conclusion.................................................................77

References............................................................ 81

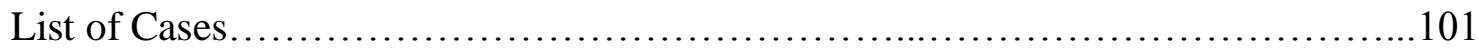

Appendix I: Sexual Violence Cases in the International Criminal Tribunal for

Rwanda...............................................................................105

Appendix II: Sexual Violence Cases Recognised in the International Criminal

Tribunal for Rwanda ...................................................................109 


\section{Table of Abbreviations}

\begin{tabular}{|c|c|}
\hline $\begin{array}{l}\text { Beijing Declaration and Platform for } \\
\text { Action }\end{array}$ & BPDA \\
\hline General Assembly & GA \\
\hline Human Immunodeficiency Virus & HIV \\
\hline Human Rights Watch & HRW \\
\hline Institute for Women's Policy Research & IWPR \\
\hline $\begin{array}{l}\text { International Committee for the Red } \\
\text { Cross }\end{array}$ & ICRC \\
\hline International Criminal Court & ICC \\
\hline International Criminal Law Series & ICLS \\
\hline International Criminal Tribunal & ICT \\
\hline $\begin{array}{l}\text { International Criminal Tribunal for } \\
\text { Rwanda }\end{array}$ & ICTR \\
\hline $\begin{array}{l}\text { International Criminal Tribunal for the } \\
\text { former Yugoslavia }\end{array}$ & ICTY \\
\hline International Humanitarian Law & IHL \\
\hline $\begin{array}{l}\text { International Research and } \\
\text { Documentation Centre for War Crimes } \\
\text { Trials }\end{array}$ & ICWC \\
\hline Kachin Women's Association Thailand & KWAT \\
\hline Rwandan Patriotic Front & RPF \\
\hline Security Council & $\mathrm{SC}$ \\
\hline Sexual Violence & SV \\
\hline Special Court for Sierra Leone & SCSL \\
\hline United Nations & UN \\
\hline Victim and Witness Support Section & VWSS \\
\hline $\begin{array}{l}\text { War Crimes Court in Bosnia- } \\
\text { Herzegovina }\end{array}$ & $\mathrm{BiH}$ \\
\hline
\end{tabular}




\section{Chapter One: Introduction}

Rwanda, a small country located in central Africa, is home to one of the most brutal and intensive killing campaigns to have occurred in the 20th century. History of ethnic tension between the Hutu and the Tutsi, the two main ethnic groups that occupy the region, can be traced back to the end of the Belgian colonial period in the 1950s. However, by the time Rwanda gained independence in 1962, a new cycle of ethnic violence began to emerge, accompanying the gradual shift in political power from the Tutsi community to that of the Hutu (United Nations (UN), 1996). From then on, tension between the two ethnic groups continued to worsen. When Hutu Rwandans gained full control of the government in 1963, violence escalated, forcing thousands of Tutsi to seek refuge in neighbouring countries (Valentino, 2004). During the winter of 1963-64, the new Hutu Government instigated "a new wave of anti-Tutsi violence" causing the death of approximately 10,000 Tutsi (Valentino, 2004: 179). These events eventually led to the establishment of the Rwandan Patriotic Front (RPF) (a political Tutsi organisation), who began to fight for equal recognition (UN, 1996).

In August 1993, the RPF gained full recognition and was granted an equal share of political power under an internationally mediated peace agreement (UN, 1996). In spite of this, Hutu extremists devised their own solution and began plotting genocide. On April 6 ${ }^{\text {th }}$, 1994, President Habyarimana died when his plane was shot down. Hutu extremists within his party immediately assumed power, and implemented a policy to annihilate the Tutsi and any moderate Hutu who supported them (Jones, 2004). Throughout a 100 day period, between April $6^{\text {th }}$ and July $16^{\text {th }}, 1994$, more than 800,000 men, women and children were murdered within Rwanda ${ }^{1}$ (Human Rights Watch (HRW), 2003).

After much delay ${ }^{2}$, the UN recognised that effective measures needed to be implemented to prevent further violence. It also became apparent that more long-term legal measures needed to be considered to investigate the events that had already taken place, and to ensure those responsible for serious violations of international

\footnotetext{
${ }^{1}$ For a more detailed and comprehensive account of Rwandan history, and the lead up to the genocide, see Prunier (1995).

${ }^{2}$ An Independent Inquiry report noted that the UN failed to prevent, and subsequently stop the Rwandan genocide. This failure was attributed to limited UN resources and a lack of political will (Carlsson, SungJoo \& Kupolati, 1999).
} 
humanitarian law (IHL) would be brought to justice (UN, 1996). In the wake of the genocide, the UN Secretary-General established an impartial Commission of Experts who were responsible for carrying out extensive investigations of genocide, crimes against humanity and war crimes (SC, 1994a). The main goal of the Commission was to establish the applicable norms of IHL which had been violated and determine individual culpability for these crimes. The Commission considered the practicability of bringing perpetrators to trial before a domestic or International Criminal Tribunal (ICT) (UN, 1996). Following its investigations, the Commission recommended that the Security Council (SC) take effective measures to ensure that individuals responsible for violations of IHL would be brought to justice before an ICT (SC, 1994a: 2). Shortly thereafter, the SC established the International Criminal Tribunal for Rwanda (ICTR) on November $8^{\text {th }}, 1994$, for the prosecution of those responsible for genocide and other serious violations of IHL, committed between January $1^{\text {st }}$ and December $31^{\text {st }}, 1994$ (SC, 1994b).

The UN has - in the establishment of the ICTR - made considerable efforts to provide a sense of justice for those who have suffered violations of IHL in Rwanda. This thesis shows that this Tribunal has been successful in bringing high-ranking perpetrators to account, in addition to developing further international jurisprudence on human rights violations. However, the ICTR's contributions to 'justice' have been quite ad hoc, especially when one considers how the ICTR has dealt with genocide survivors, particularly those who were subjected to gross acts of sexual violence (SV).

Throughout the Rwandan genocide, violence took on gender-specific forms which set out to target men and women in very different ways. Men were primarily the victims of killings (Jones, 2004), whereas women were targeted in a campaign of mass $\mathrm{SV}^{3}$ (HRW, 2003). SV was so widely used against females that the Organisation of African Unity (2000: Paragraph 16.20) concluded that "almost all females who survived the genocide were direct victims of rape or other SV, or were profoundly affected by it". Degni-Segui's (1996) report details that under-aged girls and elderly women were not spared, with those aged between 10 and 65 falling victim to SV. Heavily pregnant women were also raped, many of whom later miscarried or gave birth prematurely

\footnotetext{
${ }^{3}$ Throughout the genocide, Tutsi men and boys were also subjected to SV, although in far fewer numbers (see Brouwer, 2005: 13; Leavy, 2010: 46).
} 
(Nowrojee, 1996). While the exact number of SV victims is not known, it is estimated that between 250,000 and 500,000 Rwandan women and girls were subjected to rape, along with other forms of SV (Etchart \& Baksh, 2005; HRW, 2003).

Within the context of genocide, SV victims were also targeted on the basis of their ethnicity. SV was specifically used as a tool to "terrorise, dishonour, demoralise and divide the targeted [Tutsi] group" (African Rights \& Redress, 2008: 86). Thus, Tutsi women and girls were the main victims of SV. The anti-Tutsi propaganda proved instrumental in encouraging SV against Tutsi women. Hutu propaganda portrayed Tutsi women as "enemy infiltrators" (Carpenter, 2008: 629), referring to them as "seductress spies" and "lethal serpents" (Flanders, 2000: 97). The Hutu Ten Commandments were one of the most obvious forms of propaganda, and the sexuality of Tutsi women was explicitly targeted in four out of ten of these commandments ${ }^{4}$ (see African Rights, 1995: 42-43). However, moderate Hutu women also became the targets of SV, as well as Hutu women that were married to Tutsi men, protected Tutsi, or were politically affiliated with them (Brouwer, 2005).

The forms of SV that took place were varied and included individual rape, gang rape, rape by incest, and rape with sticks, guns or other objects (Nowrojee, 1996). Sexual enslavement was also commonly documented, where victims were kept and raped for days or weeks in specifically designated 'rape houses', or in the homes of perpetrators (Coomaraswamy, 1998). SV also included instances of forced marriage, forced labour and sexual mutilation (Nowrojee, 1996). Sexual mutilation was particularly common: women's labia were cut with machetes and other sharp objects, such as bottles, or sticks; hand-made, sharpened spears were inserted into their genitalia; their buttocks and breasts were commonly cut off; and, the uteri of some women were completely removed (Flanders, 2000). Nowrojee (1996) also detailed that, in one incident, acid was used to mutilate a woman's sexual organs. In other cases, reports confirm that boiling water was used to scald victims' vaginas (Jones, 2004). Many SV victims were also forced to undress and exposed to "public mockery" and sexual humiliation before being subjected to rape and other acts of SV (Degni-Segui, 1996: 8).

\footnotetext{
${ }^{4}$ For example, the first Hutu commandment stated that, "We shall consider a traitor any Muhutu who: marries a Tutsi woman, befriends a Tutsi woman, or employs a Tutsi woman as a secretary or a concubine" (African Rights, 1995: 42).
} 
These brutal acts were perpetrated in public places, including, but not limited to, streets, roadblocks, churches, government offices, communal centres, refugee camp sites, hospitals and near to mass graves. SV was also perpetrated behind closed doors; in the homes of victims, in the homes of perpetrators, or in other private and secluded locations (Nowrojee, 1996). SV perpetrators were mainly members who belonged to the Interahamwe (the Hutu militia groups). However, SV was also perpetrated by soldiers of the Rwandan Armed Forces, including the Presidential Guard, and by other civilians (Brouwer, 2005). In some instances, soldiers and militia men forced men to rape their own daughters and wives (Nowrojee, 1996). Furthermore, military and political leaders, as well as heads of militia, directed, encouraged and condoned Hutu men to rape Tutsi women and girls to further their political goal: the destruction of the Tutsi as an ethnic group (HRW, 2004).

SV was often committed in combination with other rights violations. Brouwer (2005), for example, noted that before the massacres took place, women and girls were specifically 'put aside' and subjected to SV, only to be murdered after these ordeals. The bodies of these victims were frequently left with their legs spread-eagled in public view, covered in semen and blood (Nowrojee, 2005). When Tutsi homes were raided, SV was commonly perpetrated in front of the victim's family or after the victim had witnessed her family being murdered (Nowrojee, 1996). For example, Tutsi husbands and sons were frequently murdered first, before their female loved ones, who were later raped and tortured before being murdered (Degni-Segui, 1996). Thus the Special Rapporteur, working for the UN Commission of Human Rights, concluded that females "may be regarded as the main victims of the massacres, with good reason, since they were raped and massacred and subjected to other brutalities" (Degni-Segui, 1996: 6).

For SV victims who survived these ordeals, their suffering continued. Many faced significant problems, including social stigmatisation, poor physical and psychological health, unwanted pregnancy and severe poverty (Nowrojee, 1996: 3). In many instances, $\mathrm{SV}$ victims were forced to cope with these challenges, along with the loss of family members, on their own (Brouwer, 2005). Like in many societies, SV carries a heavy burden of shame and social stigmatization in Rwanda (HRW, 2003). Consequently, SV victims were commonly viewed as tainted and un-marriageable. They faced rejection from their families, their loved ones and wider society. In some instances, victims were 
even blamed for their assault and accused of collaborating with the enemy (Mukangendo, 2007).

In the wake of SV, many victims also required urgent medical attention, as well as psychological care, which was largely unavailable (Brouwer, 2005). However, even when services were available, some victims were too afraid to access them due to the heavy burden of shame attached to SV (Amnesty International, 2004). Many victims were also faced with long term medical complications, especially in instances where they had been sexually mutilated or had contracted sexually transmitted diseases (HRW, 2004). Amnesty International (2004) noted that the genocidal campaign of mass SV, perpetrated throughout the genocide, contributed significantly to the spread of human immunodeficiency virus (HIV). In 2005, the Rwandan organisation Avega, tested 1,200 SV victims for HIV, and discovered that two-thirds of these women had been infected with this deadly disease (Mcgreal, 2005). Men who were HIV positive both intentionally and unintentionally passed their disease onto their victims through rape (Mullins, 2009).

Furthermore, the National Population Office of Rwanda estimated that between 2,000 and 5,000 children were born from rape committed throughout the genocide, which caused significant difficulties for victims (Mukangendo, 2007: 40). Anti-abortion laws in Rwanda saw some victims attempt to abort these pregnancies on their own, resulting in further medical complications, and in some instances, even death (Amnesty International, 2004). Victims who went to full term were left to care for children born from rape (Nowrojee, 1996). These children were rejected from some mothers who labelled them "little Interahamwe" and "children of shame" (Degni-Segui, 1996: 9). Struggling with these difficulties, some women resorted to committing infanticide (Nowrojee, 1996).

Other harms connected to SV have been further debilitating. Post-genocide, 70 percent of the surviving population was made up of females (Porter, 2007: 172). Thus many women and girls became the breadwinners of their families, while others were forced into 'opportune marriages' to regain economic stability. Many victims found it difficult to get work, particularly when they were faced with severe medical complications 
following SV (Brouwer, 2005). Faced with these challenges, many SV victims went without food, healthcare, education and shelter following the genocide (HRW, 2004).

Despite the widespread and systematic nature of SV that occurred during the Rwandan genocide, in combination with the long lasting effects and consequences of this violence, SV does not appear to have been a main concern for the UN's ICTR (African Rights \& Redress, 2008; Carpenter, 2008; Galina, 2010; Nowrojee, 2005). The ICTR's primary focus has been geared towards investigating and prosecuting crimes of genocide and other rights violations, which has significantly limited the opportunities for SV victims to obtain legal 'justice'. This thesis critically evaluates both the successes and shortcomings of this Tribunal, in relation to how it has responded to SV committed against women and girls throughout the Rwandan genocide.

\section{Legal Justice for Sexual Violence Victims}

Historically, SV was viewed as an inevitable and inconsequential aspect of conflict (Haffajee, 2006). International legal doctrines have rarely referred to SV and, in doctrines where SV has been mentioned, ICTs have largely failed to charge or sanction it (see Brouwer, 2005; Copelon, 1994; Levy, 1994; Niarchos, 1995). The press reports covering the former Yugoslavian conflicts of the 1990s, however, helped to expose SV as an issue that needed to be recognised and addressed (Sharlach, 2000). In Bosnia and Herzegovina alone, thousands of women and children were systematically raped and murdered in organised military 'rape camps' (Seifert, 1994). Following extensive documentation of these atrocities ${ }^{5}$, the UN was pressured into addressing SV as a crime of international proportions (Levy, 1994: 258). In 1993, the UN's SC established the International Criminal Tribunal for the former Yugoslavia (ICTY) for the prosecution of individuals who had committed violations of IHL in the Balkans. The UN's SC declared that the "massive, organized and systematic detention and rape of women...in Bosnia and Herzegovina" was a serious violation of IHL (SC, 1993: 1). In an effort to ensure that SV perpetrators did not evade criminal prosecution, rape was explicitly defined as a crime against humanity under Article 5(g) of the ICTY Statute (ICTY, 2009a: 6). Consequently, the ICTY became the first ICT to exclusively deal with crimes of SV (Institute for Women's Policy and Research (IWPR), 2005). This allowed for the ICTY

\footnotetext{
${ }^{5}$ Galina (2010) argues that women's groups and NGO's have played an important part in exerting pressure on the UN, to respond to atrocities specifically directed at women and girls in conflict.
} 
to make a number of landmark judgements wherein rape was recognised and successfully prosecuted as a crime against humanity, a war crime and as an act of genocide (ICTY, 2012).

Following these feats, the UN has not only worked towards recognising SV in conflict within its wider framework, through passing multiple resolutions condemning such practices $^{6}$, but has continued to define, prosecute and punish SV in other UN established ICTs. As this thesis demonstrates, ICTs have begun to build a progressive response to SV in conflict, and have created new opportunities for SV victims to obtain legal 'justice'. Nevertheless, ICTs have been heavily criticised for their reluctance to rigorously investigate and prosecute SV (Askin, 2005; Coomaraswamy, 2005; Galina, 2010; Nowrojee, 2005). This can be seen when examining international trends which reveal that ICT indictments, containing SV charges, are still vastly underrepresented in comparison to other crimes ${ }^{7}$. In cases where $\mathrm{SV}$ has been pursued, international criminal justice processes and procedures have hindered participation, validation and acknowledgement of its victims (Henry, 2009). In particular, research demonstrates that ICTs have failed to respond to SV in a way that is sensitive to the gendered nature of this crime and the needs of its victims (Brouwer, 2005; Galina, 2010; Nowrojee, 2005; Sharratt, 2011). Askin (2005), for example, argues that a lack of gender expertise has meant that harmful stereotypes surrounding SV have shamed, re-victimised and silenced SV victims within ICT proceedings. Consequently, even when SV has been successfully prosecuted, the majority of its victims have been left dissatisfied with the outcome, and are commonly traumatised by their court experiences (Mertus, 2004; Sharratt, 2011).

From these observations, it becomes paramount to consider how SV cases progress through ICTs, in order to understand the effectiveness of the international legal system. This thesis critically evaluates both the successes and shortcomings of the UN's ICTR, in relation to how this Tribunal has responded to SV, and subsequently delivered justice to its victims. Learning more about how the UN's ICTR has addressed SV in Rwanda is

\footnotetext{
${ }^{6}$ In 2000, the UN SC passed the first resolution concerned with the impact that armed conflict has on women. SC Resolution 1325 emphasized that it was the responsibility of all states to end impunity for war crimes, including SV against women and girls. Furthermore, it called upon all parties to take special measures to protect women and girls from gender-based violence in conflict (SC, 2000a). The UN SC has subsequently passed other relevant resolutions, including Resolution 1820 (SC, 2008), 1888 (SC, 2009a), 1889 (SC, 2009b) and 1960 (SC, 2010).

${ }^{7}$ See for example, Askin (2005), Grewal (2010: 65-68), Nainar (2012) and Nowrojee (1996).
} 
paramount given the 'frame-setting' nature of the UN as a whole. The UN helps "develop the rules, standards, laws and institutions that make orderly social life possible at the international level" (Barnett \& Finnemore, 2007: 47). In this respect, the UN helps set the tone for international discussions, policies and practices towards SV. By examining UN responses to SV in conflict, one can gain a clearer picture of the international framework that has been employed, and attain a stronger understanding of the development that may still be required within this area of IHL.

Before this discussion can proceed, it is necessary to establish the parameters of this thesis. Although SV is perpetrated against women, men and children in conflict, it affects women and girls disproportionately (Baksh \& Etchart, 2005). Thus, the Beijing Declaration and Platform for Action (BDPA) (1995) recognised that women and girls are undoubtedly at greater risk of SV (an issue apparent in the Rwandan situation). Furthermore, they face significant gender-related barriers when seeking legal redress for crimes of SV in all national and international legal systems (BDPA, 1995). Therefore, this thesis critically evaluates the UN's ICTR, in relation to how this Tribunal has both secured and limited opportunities to 'do' justice for sexual violence (SV) victims ${ }^{8}$. This thesis also defines SV as "any violence, physical or psychological, carried out through sexual means or by targeting sexuality" (McDougall, 1998: 7). The definition is deliberately broad, in an effort to capture the wide spectrum of sexually violent acts committed against females in conflict. This is important given that, as shown above, SV is not limited to rape; it includes a wide range of other harmful acts such as forced nudity, forced prostitution, sexual mutilation, sexual slavery, forced impregnation and other harmful sexual acts.

\section{A Feminist Theoretical Approach}

This thesis employs a feminist theoretical approach to research in investigating how the UN's ICTR has both secured and limited opportunities for SV victims to achieve 'justice'. Critically reflecting on the lived experiences of women is useful, as it helps inform one's understanding of the social world (Letherby, 2003). Epstein (2007)

\footnotetext{
${ }^{8}$ While this thesis concerns SV committed against women and girls in conflict, it primarily considers how justice has been secured within ICTs for women. The reasons for this are that (i) children present a whole new range of vulnerabilities within the court room, and their experiences need to be addressed in that context (ii) SV witnesses before the ICTR were adults, thus the experiences of girls was limited within court processes.
} 
observes that, globally, women hold a subordinate position to men and remain disadvantaged in social, economic and political aspects of life. In response, feminist research is primarily interested in producing knowledge that will help to transform gendered injustice and subordination (Ramazanoglu \& Holland, 2002). Feminist researchers critically examine the status and treatment of women within the "sexist, male-stream and patriarchal" societal order, in the hope of exposing social practices that have "displaced, ignored and silenced women", or resulted in an unequal and discriminating order (Sarantakos, 1998: 54). In this sense, research is not distinguished as being feminist on the sole basis that it investigates gender or gendered social lives, but because of the normative framework that it utilises (Ramazanoglu \& Holland, 2002).

This thesis uses a broad theoretical framework that is directly focused on 'justice'. Political philosopher, Nancy Fraser (2007a), believes that to achieve justice, social arrangements need to enable all individuals to participate on a par with others. Based on this presumption, Fraser (2007a) devised a theoretical model focused on three interlocking dimensions of justice: (i) recognition, which demonstrates the way sociocultural patterns of value impact upon how individuals are recognised; (ii) redistribution, which focuses on the way structural injustices, determined by status disparities, affect how individuals gain access to resources which enable them to participate on a par with others; and (iii) representation, which illustrates the way membership and procedural issues determine how individuals can pursue justice claims.

Using Fraser's (2007a) tripartite model of justice as a theoretical backdrop, this thesis critically evaluates the ICTR, in relation to how this Tribunal has both secured and limited opportunities to 'do' justice for sexual violence (SV) victims. In her article Feminist Politics in the Age of Recognition, Fraser (2007b) applied her theoretical approach to gendered justice, and examined the practical problems that arise when securing justice for women. However, her approach is more holistic, as it situated gender struggles for justice as one social differentiation among others (such as 'race', ethnicity, sexuality, religion or nationality) (Fraser, 2007b: 29). This thesis engages with Fraser's (2007a) tripartite model in terms of how it relates the gendered framework of international criminal justice. In doing so, this thesis does not intend to downplay the importance of other status disparities, but rather seeks to provide a more comprehensive 
understanding of the difficulties that women face in their pursuit for 'justice' for crimes of $\mathrm{SV}^{9}$.

Some critics of feminist research have been sceptical of placing women at the helm of social inquiry (Letherby, 2003). Jones (2004: 126), for example, argues that any research project that focuses exclusively on women is likely to leave "a vast analytical terrain untouched or poorly explored". He suggests that, while focusing on women and their experiences of conflict is important, if there are no gender-specific studies conducted on the experience of men in conflict, men's experiences run the risk of being suppressed. However, feminist scholars advocate conducting isolated studies on women because most knowledge has been previously dominated by men, and focuses almost exclusively on men (Heidensohn \& Gelsthorpe, 2007). Therefore, this thesis does not seek to actively suppress the experience of men as Jones (2004) suggests, but rather hopes to advance the current position of women, by bringing their previously neglected experiences to the foreground.

\section{Methodology}

The research for this thesis was undertaken using qualitative documentary analysis. Documentary analysis is defined by Jupp (2006: 41) as a "detailed examination of documents across a wide range of social practices". He suggests that upon analysing a set of documents, a researcher will come to learn about a document's authenticity, credibility, representativeness and meaning. Researchers carrying out documentary analysis, however, are most interested in the meaning and content of the documents examined (Yeboah, 2008). Scott (1990) indicates that the purpose of 'doing' documentary analysis is to come to some understanding of the meaning and significance of what the documents contain, and how this information enables a researcher to answer their research questions.

The four key stages of documentary analysis, as identified by Sarantakos (1998), are: the identification of documents, the organisation and analysis of documents, the evaluation of the obtained information, and finally, the interpretation of the collected data. However, unlike other research methods, there is no clear methodological way to

\footnotetext{
${ }^{9}$ It is important to recognise, however, that status disparities often overlap which can result in further disadvantage when making justice claims (Fraser, 2007a).
} 
'do' documentary research, as it encompasses a variety of different approaches to data analysis (Jupp, 2006). This thesis pursues an analysis that is focused upon:

Manipulating the documents and studying the text in a very detailed and analytical way. More particularly, the text is read and conclusions are made on issues that are beyond the language (e.g. meaning, purpose, etc) in a qualitative or a quantitative manner. (Sarantakos, 1998: 207)

This approach assumes that there is much to learn about the material items produced within culture. For example, it is understood that a researcher can "learn about social life, such as norms, values, socialisation, or other social stratification" by examining the texts that individuals and institutions produce (Leavy, 2007: 229). From a feminist perspective, employing these practices is particularly useful, as the texts and objects that groups of people produce often provide traces of the larger ideas these groups have, such as ideas related to gender (Leavy, 2007). Atkinson \& Coffey (2004) note that studying institutional documents is particularly useful, as it enables a researcher to learn more about that organisation and how it operates. In particular, the documents that institutions produce are generally laden with its cultural values (Atkinson \& Coffey, 2004). This was significant given that this research was interested in determining how the UN's ICTR has responded to SV victims in Rwanda, and whether the institutional and operational practices employed to address SV have accommodated women in their pursuit of justice.

The principal aim of this thesis was to analyse the documents in a qualitative manner (although this thesis does employs some simple quantitative analysis). This qualitative approach allowed for the development of a more informed and critical understanding of how the UN's ICTR has managed its discourse on SV, and responded to its victims within the justice process. The following section will detail how these methods were undertaken.

\section{Research Methods}

The data informing this research was collected from completed ICTR cases that contain references to SV. The following sections detail how this research was approached in relation to Sarantakos' (1998) stages of documentary analysis mentioned above. 


\section{Identifying Relevant Documents}

In order to access completed ICTR cases, I used the online database available on the ICTR website (http://www.unictr.org). This website gave me access to the indictments, trial chamber judgements, sentences and appeal chamber decisions for each case. In order to identify cases containing references to SV, I downloaded all applicable documents for all 43 completed cases, and then searched through each individual document. To speed up the process, I created 'search words' that were entered into the Full Reader Search of the Adobe Reader Software Programme (which was used to view each legal document downloaded). The search words used were explicitly related to sexually violent acts, such as 'SV', 'rape', 'sex', 'sexual', 'sexual assault', 'sexualised violence', 'genital mutilation', 'sexual mutilation', 'forced nudity' and 'sexual slavery'. However, this process was not as straight forward as initially thought, as the ICTR database only contained the most recent documents for each case. For example, if SV charges were included in the 'original indictment', but were subsequently dropped, they would not be included in the 'amended indictment' (the only indictment made available). Therefore, cases originally containing SV charges could be easily missed. To remedy this problem, I obtained access to the Jurisprudence Library (ICTRcaselaw.org), which contained all required documents. Of the 43 cases examined, a total of 25 contain references to SV committed against Rwandan women and girls, of which 23 formed the basis of this research (see Appendix I \& II). At the time of writing, 17 additional cases were awaiting appeal. These cases were not included in this research.

\section{Organising and Analysing Documents}

The indictments, trial chamber judgements and appeal chamber decisions of each of the 23 identified cases were used throughout the organisation and analysis stages of research. However, the trial and appeal judgements have dominated this analysis, as they provide a detailed description of the SV allegations, the applicable elements of law and the Chamber's subsequent legal decisions. In order to make this research manageable ${ }^{10}$, I wrote case summaries for each of the 23 cases. After noting various themes relating to the outcome of each case, I organised the cases into five categories: (i) cases where successful convictions have been entered for SV crimes; (ii) cases where SV convictions have been overturned on appeal; (iii) cases where individuals have been

\footnotetext{
${ }^{10}$ Some documents were over 800 pages in length.
} 
acquitted of SV charges; (iv) cases where SV charges have been dropped or subsequently withdrawn; and, (v) other relevant cases. I then developed a table which indicates how acts of SV have been prosecuted in the ICTR crimes process (see Appendix I). This table can be used as a quick 'go to' reference detailing the outcome of each case.

When using quantitative content analysis to review each case, I documented the following: the number of adjudicated cases originally containing SV charges; the number of cases that dropped SV charges before making it to court; the number of successful convictions pertaining to SV charges; the number of cases that contain SV acts that underpinned convictions for other crimes; the number of unsuccessful convictions pertaining to SV charges; and, the number of convictions concerning SV that had been overturned on appeal. These figures form a quantitative record indicating how crimes of SV has been recognised and prosecuted within the ICTR crimes process. These results are presented in Chapter Four.

The main body of information was obtained by examining the selected documents in a qualitative manner. When using qualitative documentary analysis, I looked for specific themes related to how the ICTR had secured or limited justice for SV claimants. These themes were constructed from the 'ground up', after conducting the literature review and reading through each case. They were also informed by Fraser's (2007a) tripartite model of justice, based on principles of recognition, redistribution and representation.

The main themes that have guided this qualitative analysis are:

\section{- Case Outcomes Pertaining to SV Allegations}

In cases that secured successful outcomes concerning SV and/or related charges, I documented the Chamber's legal findings. In particular, I recorded the applicable elements of the law that had been applied, and the important SV rulings concerning how these acts had been prosecuted. I also explored how SV had been prosecuted, either as crimes against humanity, genocide or war crimes. If cases resulted in unsuccessful outcomes, I documented the reasons why, such as burden or lack of evidence, defective 
indictments, or failure to link those accused to the alleged crimes. I also documented cases where the Prosecution had failed to appeal unsuccessful SV convictions.

\section{- The Differential Construction of SV Within the Legal Framework of the ICTR}

I gathered information concerning how SV had been defined, documenting how these conceptual definitions varied across and between cases. Similar patterns quickly emerged, where conceptual definitional frameworks of SV focused on: consent versus coercion; mechanical versus non-mechanical definitions of rape and SV; and, broad versus narrow interpretations of SV. When documenting these trends, I also looked at the Tribunal's explanations for why differential definitions had been adopted. However, Chamber decisions were not only informed by ICTR cases; they included and referred to judgements made in the ICTY. Therefore, I reviewed ICTY cases that had applied the definitional frameworks that had later been employed by the ICTR.

\section{- Re-Victimisation and Insensitive Court Practices}

As indicated above, the literature demonstrates that ICTs have failed to address SV in a way that is sensitive to the gendered nature of this crime and to the needs of its victims. Therefore, this theme was pursued to determine whether the documents indicated mistreatment of SV victims, or that insensitive court processes and procedures were used. In particular, I noted the questions that women were asked by the Tribunal staff on cross-examination, and the appropriateness of them. I also documented the questions asked on cross-examination that required women to conform to the mechanical nature of rape (which sometimes involved an intimate description of body parts), or answer questions regarding the non-consensual aspects of these crimes. The prevalence of rape myths within judicial proceedings was also considered, in order to understand more about the institutional and cultural framework of the ICTR.

\section{- The Adversarial Court System and Silencing of SV Victims}

This theme focused on how women had been silenced within the ICTR, as a result of the way the adversarial court system operates. Henry (2009), for example, observed that the adversarial court system operates as a fact-finder and does not always allow women to share their personal narratives in the way they desire. Therefore, I carefully explored 
how women's testimonies had been silenced or interrupted; documenting, for example, instances where the ICTR concentrated on proving 'hard legal facts', as opposed to letting the victim express her account in her own words.

\section{Evaluation and Interpretation of the Data}

As a theoretically-driven project, the evaluation and interpretation stages of research owe much to Fraser's (2007a) model of justice based on recognition, redistribution and representation. These dimensions of justice ultimately determined how I evaluated and interpreted my research findings. My methodological approach, however, skewed the nature of the findings in favour of issues concerned with recognition. As demonstrated in the following chapters, representation and redistributive aspects of justice are closely related to the social and structural context in which justice claims are made. Therefore, most findings were centred on themes related to securing and limiting recognition within the ICTR crimes process. While the ICTR documents did provide some insight into issues associated with representation, they provided virtually no information on redistribution. Realising this limitation, I looked to the wider literature on the ICTR, and extracted information from reports and publications concerning the ICTR. I then correlated my research findings with the broader literature, in order to give meaning to the debate on how justice has been secured or limited for SV victims.

\section{Chapter Overview}

Chapter Two explores the phenomenon of SV in conflict. The chapter begins by acknowledging that the 'issue' of SV committed against women and girls in conflict has been ignored by academia, in spite of its prominence throughout history. Acknowledging this neglect, the chapter provides a conceptual backdrop to SV committed against females during conflict, exploring its causes, functions and consequences. In doing so, SV is framed as a 'problem' that requires recognition in international justice mechanisms. The chapter then introduces Fraser's (2007a) tripartite model of justice based on the: socio-cultural dimension of recognition; the economic dimension of distribution; and the political dimension of representation.

Chapter Three critically engages with Fraser's (2007a) model in relation to gendered injustice, focusing on how justice can be secured for SV victims in international justice 
mechanisms. More specifically, the chapter considers the broader feminist literature on international legal justice and critically explores how the UN ICTs have both secured and limited opportunities for women, who have suffered SV, to attain justice. In doing so, Chapter Three creates a backdrop for how SV cases have been judged in the ICTR.

Chapter Four presents the research findings that illustrate how justice has been secured and limited for SV victims within the ICTR. These findings are correlated with the broader literature on this Tribunal. The chapter acknowledges that the ICTR has facilitated justice for SV victims by successfully defining, prosecuting and punishing $\mathrm{SV}$, but observes that crimes of SV have been constructed and responded to in ad hoc and skewed ways. Chapter Four reveals that problems with the institutional framework, institutional incapacities and participation limit and, in some cases, undermine positive practices of recognition. Furthermore, the chapter details that this Tribunal has largely failed to address concerns related to redistribution, which has negatively impacted on how justice is experienced by SV victims.

Chapter Five critically discusses these findings, in relation to the main features of Fraser's (2007a) theoretical framework and the findings from the wider literature. This chapter argues that while the ICTR may have facilitated some recognition for SV victims, it has failed to build an organisational culture and framework where SV has been systematically addressed and rigorously prosecuted. The outcomes of cases tended to be a product of individual prosecutorial decision-making, rather than a structured response to SV. 


\section{Chapter Two: Justice for Conflict-Related Sexual Violence Victims}

During the Twentieth and Twenty First centuries, violence during conflict has moved away from the 'battlefield' and further into the community (Etchart \& Baksh, 2005). Consequently, civilian populations are now considered to be more likely among those counted as human casualties of conflict (see Cairns, 1997). In addition, women and children (and some men) have become increasingly vulnerable to SV in conflict (Etchart \& Baksh, 2005; Mullins, 2009; Reilly, 2007). However, the occurrence of SV in conflict is by no means a 'new phenomenon'.

History reveals that the ancient Greek, Persian and Roman troops routinely raped the women of their conquered enemies; and during the Crusades, knights and pilgrims, who were supposedly bound by vows of chivalry and Christian holiness, raped women (Siegel, 2011). In the Seventeenth Century, Spanish troops committed countless numbers of rapes against women in the Netherlands (Estep, 1986). During WWII, thousands of women were forced into prostitution and routinely raped by men serving in the Japanese military (Yoshimi \& O'Brien, 2000), while Russian soldiers raped thousands of German women in Berlin at the end of WWII (Goldstein, 2001). Furthermore, in 1992, 20,000 Muslim and Croatian women and children were raped in specifically designated 'rape camps' in Bosnia (Seifert, 1994); and, at the time of writing, sexual brutalities against women and girls were being committed by government forces and pro-government militia during house raids, in Syria (Sherlock, 2012). These examples demonstrate that SV in conflict has occurred in different times, spaces and societies, thus making it a key element of conflict and war making making activity $^{11}$.

Yet, despite its prominence, SV in conflict has been one of history's greatest silences (Copelon, 1994). For centuries, SV was very simply regarded as an inevitable byproduct of conflict (Goldstein, 2001). Thus SV became an accepted norm and a tolerated feature of the 'spoils of war' (MacKinnon, 1994). While other aspects of conflict have received detailed consideration, academic scholarship dedicated to exploring the complex causes and consequences of SV was nonexistent up until the

\footnotetext{
${ }^{11}$ For a detailed history of SV committed in conflict, see Heineman (2011).
} 
1970s. It is only in the past three decades that scholars have begun to acknowledge SV in conflict as an area worthy of critical academic investigation.

Developing a theoretical and conceptual backdrop to SV in conflict has proven extremely valuable, mainly because it has helped to secure a place for SV on the international legal agenda. Given that women and girls are at an increased risk of SV, and present the majority of its victims (Brouwer, 2005), this chapter attempts to unearth some of the important theoretical contentions concerning the causes and functions of $\mathrm{SV}$ against females. The meanings given to SV in conflict are important to consider, because they help contextualise why SV is such an effective 'weapon of warfare'. However, this chapter will also discuss some of the consequences SV has for its victims in order to highlight the seriousness of this violation. In light of these observations, this chapter works towards establishing the importance of addressing SV in international legal mechanisms. Therefore, the last section considers how justice might be secured by SV victims, based on Fraser's (2007a) tripartite model of justice.

\section{The Causes and Functions of Sexual Violence in Conflict}

$\mathrm{SV}$ in conflict first made its way onto the academic agenda in the late 1970s, when Susan Brownmiller (1975) pioneered research on the politics of SV. She famously declared that "rape is nothing more or less than a conscious process of intimidation by which all men keep all women in a state of fear" (Brownmiller, 1975: 5). Rejecting previous theories which saw SV as a problem of abnormal irrationality and individual pathology (see Rada, 1978), or theories grounded in the assumption that SV resulted from oversexed men (see Thornhill \& Palmer, 2000), Brownmiller (1975) argued that SV could be explained by examining the highly political social structures of society. She claimed that SV had deep patriarchal ${ }^{12}$ roots, and was used to reinforce the unequal position between men and women, both in times of peace, and in times of conflict. Despite heavy criticism ${ }^{13}$, Brownmiller's (1975) work mobilised feminist thought into

\footnotetext{
12 Patriarchy is a hierarchical order of dominance, whereby men hold elite power over women and children (McCann \& Kim, 2002: 221).

${ }^{13}$ Although acknowledging Brownmiller (1975) for her innovative work on rape, Dubinsky (1993: 135) criticised that she failed to adequately address the complex relationship that exists between social structures and ideologies that support conditions for patriarchal dominance. In particular, she argued that Brownmiller's (1975) conceptualisation of rape relied too heavily on "an ahistorical and essentialist conception of 'all women's' and 'all men's experience”. Furthermore, Davis (1983: 177) argued that
} 
acknowledging SV in conflict as an area of concern that needed further academic consideration. Since Brownmiller, many other feminists have begun to unpack the apparent social causes of SV, which can be used to explain the gendered nature of this phenomenon.

Etchart \& Baksh (2005) state that SV committed against females in conflict can be understood by examining forms of gender-based violence that exist in society more broadly. They note that, although gender-based violence is not limited to females, women and girls are most vulnerable and represent the majority of its victims. Like Brownmiller (1975), they argue that the dominant social order has characterised women as subordinate to men, and this power imbalance has worked to sustain discriminatory practices which have condoned violence against women. For example, cultural practices such as wife battery, honour killings and genital mutilation have functioned to maintain the 'status quo', whereby men have exerted social control over women's lives (Baksh \& Etchart, 2005).

Leatherman (2011) explains the significance of these assertions, and details that these discriminatory practices are the social by-products of dominant or hegemonic forms of masculinity that attribute greater significance to men. For example, the practice of genital mutilation has worked to ensure that young girls remain chaste and pure until marriage, values of which are desirable and important to men. Other cultural practices, such as honour killings, have been carried out as a form of social discipline, whereby husbands and male family members have assumed the right to murder women who have committed adultery and other prohibited societal acts (Leatherman, 2011). She asserts that such practices have required a significant investment of time, social organisation and resources, and that SV committed against females in conflict can be seen in the same way. After all, such practices do not develop in isolation, but rather they derive from and feed off "pre-existing socioeconomic and culturally shaped gender relationships" (Leatherman, 2011: 3). In other words, females become prime targets for $\mathrm{SV}$ in conflict because of systemic patterns of gender subordination that exist within society generally. Through the enactment of these discriminatory practices, men have

Brownmiller's (1975) work supported the racial myth that black men are "especially prone to commit acts of violence against women". 
been able to maintain the established hierarchy of unequal gender relations, subsequently safeguarding their superiority.

Although patterns of gender inequality vary between cultures, all women experience gender inequality across social, economic and political aspects of life to some degree. Gardam (2005: 119) claims that "nowhere are women full participants in society". UN Women (2011) note that globally, women are still underrepresented in leadership and participation roles in the political sphere. By mid-2011, only 28 countries could declare that women's parliamentary representation had reached 30 percent (UN Women, 2011: 10). Economically, women still have limited access to economic assets, employment opportunities and positions of leadership. In particular, global patterns reveal that 50 percent of the world's women are in poorly paid and unstable employment, with the gender wage gap averaging between 10 and 30 percent (UN Women, 2011: 12). Women's lack of economic stability means that they are more likely to live in conditions of poverty ${ }^{14}$. Consequently, access to adequate housing, food, health care and education is largely unavailable (see Epstein, 2007). The hardships suffered by women in conflict are linked to these deep socio-structural inequalities (Colombini, 2002). However, as identified below, these structural disadvantages also limit how women gain access to 'justice' in the aftermath of SV.

However, whatever the cause of SV against females in conflict, SV arises from "different specific motivations in various wars" (Goldstein, 2001: 362). In other words, $\mathrm{SV}$ has no function that is necessarily common to all times and societies. Its functions ultimately depend on the historical, social and cultural context of the conflict in question, and must be discussed with reference to concrete cases (Seifert, 1994: 57). For instance, Sharlach (2000) argues that SV in conflict has been employed as an act of revenge against the enemy side - a motive evident in the rape of German women by Russian soldiers at the end of WWII (Goldstein, 2001). In other instances, SV has provided a service to the military. For example, throughout WWII, Japan developed a system of 'comfort women' where between 50,000 and 200,000 women were forced into sexual slavery to provide sexual services to the Japanese Army (Yoshimi \& O’Brien, 2000).

\footnotetext{
${ }^{14} \mathrm{UN}$ Women (2012) revealed that of the 1.5 billion people in this world living on less than $\$ 1$ a day, 70 percent are women.
} 
SV has also been employed as an element of torture, which commonly functions to incapacitate 'threatening' communities (Stanley, 2009). For example, during the Cambodian genocide (1975-1979), female prisoners were tortured and raped in detention centres established under the Khmer Rouge regime (see Kissi, 2006). A more recent example has been documented in the ongoing Syrian conflict, where SV has been used to torture women accused of having political connections with the Syrian rebels (see Sherlock, 2012). Scholars also argue that SV in conflict can function as an element of male communication (Baaz \& Stern, 2009; Brownmiller, 1975; MacKinnon, 2006; Seifert, 1994). Brownmiller (1975) first applied this notion to the ancient Greek warriors, who routinely raped the women of their conquered enemies. She explained that rape did not carry dishonour for Greek warriors because women of the losing side became 'legitimate booty' for the victors. In this context, SV was used to reinforce the enemy's inability to protect 'their' women, and their masculinity was thus compromised (Brownmiller, 1975). Baaz \& Stern (2009) took Brownmiller's (1975) analysis further, suggesting that $\mathrm{SV}$ in conflict is often regarded as a symbolic message of domination to both the men, who are unable to prevent the abuse, and to the women, who become victims.

Other scholars, like Goldstein (2001), have argued that the use of SV as an instrument of control and domination has significantly increased since the 1990s. He claims that modern methods of conflict explicitly target women and use "organised sexual assault as a tactic in terrorising and humiliating a civilian population" (Goldstein, 2001: 363). In support, Etchart \& Baksh (2005) assert that conflict is now commonly fought through women's bodies. This strategy is effective because women hold important cultural positions and are often considered central to the family structure within society (Seifert, 1994). In particular, women play a major role "in building and preserving the clanbased, ethnic, or cultural identity of any society" due to their sexual and reproductive abilities (Josse, 2010: 178). In this regard, systematic SV is an effective tool which demonstrates the power of the military, and subdues and humiliates an entire enemy population (Goldstein, 2001). For example, under the rule of Libyan Dictator Colonel Muammar Gaddafi, troops were ordered and instructed to rape women as a means of subjugating the civilian population (Hall, 2012). Hall (2012: 1) noted that condoms and Viagra were provided to the troops to "encourage their assaults". Widespread and systematic SV committed against women in conflict has also been documented 
throughout areas of Liberia (HRW, 2002), Sierra Leone (Baldi \& MacKenzie, 2007), Uganda (Webber \& Rone, 2003), Haiti (Coomaraswamy, 2005), Guinea (Sillah, 2009), Syria (Sherlock, 2012) and Burma (Kachin Women's Association Thailand (KWAT), 2011), among others.

Another perspective, which has gained significant attention in recent years, and is closely related to these themes, suggests that SV can be tactically adopted, and consciously employed, with the intent to destroy a group (Coomaraswamy, 2005; MacKinnon, 1994; Mullins, 2009; Sharlach, 2000). More specifically, Mullins (2009: 18) contends that rape constitutes genocide when it is systematically:

Used to generate fear in subdued populations, humiliate the population (both men and women), derogate women (through spoilage of identity), and create a cohort of mixed ethnic children to maintain the humiliation/ spoilage/ domination.

The systematic practice of SV was a key part of the wider 'ethnic cleansing' campaign committed against the Croatian and Muslim people in Bosnia and Herzegovina (Sharlach, 2000). Of the 100 concentration camps run by the Serbian forces, 20 were for the sole purpose of raping and killing Croatian and Muslim women and girls (MacKinnon, 1994: 61). Over 30,000 Croatian and Muslim females were forcibly impregnated through mass rape within these camps (MacKinnon, 1994). Pregnant women were even segregated from other women, and detained until their seventh month of pregnancy, so that abortion was no longer possible (Niarchos, 1995). In this context, rape carried a very specific function, as victims were frequently told they were being impregnated in order to create 'Chetnik babies' (MacKinnon, 1994).

This scholarship demonstrates the effectiveness of SV in conflict, in addition to the many functions that SV has. It shows that SV is commonly used against females as a strategic and orchestrated attack against the whole community. However, this discussion also identifies that the cause of SV can be inextricably linked to female subordination. These contentions are important to consider given that patterns of gender discrimination and subordination also limit women's opportunities to attain justice in the aftermath of SV. The next section discusses the consequences of SV, in order to highlight why it is vital that international legal justice mechanisms respond to such crimes. 


\section{The Consequences of Sexual Violence in Conflict}

$\mathrm{SV}$ in conflict has devastating and wide-ranging consequences for its victims. In the wake of their violation, victims may face emotional and psychological trauma, physical injuries, the threat of sexually transmitted diseases and unwanted pregnancy (Mukangendo, 2007). These consequences are further intensified, given that the social stigma surrounding SV can work to silence victims, leaving them to cope with the aftermath of such violence on their own. SV victims are commonly treated as tainted, dishonoured or unmarriageable (Askin, 2005), and are thus, marginalised by their families and the wider community (Josse, 2010). In some societies, the shame that SV brings to a family is so severe that victims may be at risk of honour killing (Baksh \& Etchart, 2005; Leatherman, 2011). Furthermore, Individuals who have suffered SV are rarely viewed as victims, and often encounter attitudes of hostility and abandonment (Mukangendo, 2007). This can lead them to feel isolated and, in some cases, they may develop feelings of guilt and self-blame (Colombini, 2002).

The psychological implications for SV victims are also readily apparent. FolnegovicSmalc (1994: 177) reveals that many victims suffer from depression, anxiety, agitation, post-traumatic stress disorder, low self-confidence, apathy, sleep disorders, and many other psychological issues. Research also demonstrates that some women struggle to resume sexual relationships with their husbands and partners, or have difficulty establishing new relationships because of psychological trauma (Colombini, 2002). Some victims can also develop avoidance behaviour to escape things that bring back the memories of the abuse. This type of behaviour disrupts a victim's day to day functioning, rendering her incapable of maintaining a normal and healthy lifestyle, where she is able to care for her family, or return to work (Josse, 2010). Moreover, the onset of physical health problems, such as vaginal discharge or pelvic pain, can cause psychological distress. Such conditions can make a victim 'feel dirty' and infected (Heise, Putanguy \& Germain, 1994). Folnegovic-Smalc (1994) argues that SV committed in conflict intensifies the psychological symptoms suffered, as the trauma is multi-layered on the basis that many women have not only suffered SV, but also the loss of their loved ones, their home, material goods and the means for their survival. 
Many victims also sustain severe physical injuries after SV; particularly those who have been subjected to sexual mutilation, gang rape, rape by objects, or repeated rape (Leatherman, 2011). The immediate psychical injuries associated with rape can include fistula, gynaecological, rectal and internal haemorrhaging (Clifford, 2008). However, in sexual attacks victims may also sustain other related injuries including broken bones, wounds and blunt trauma to the body (Nowrojee, 1996). More long term physical injuries can remain with some victims. In cases where women have been sexually mutilated, or where they have suffered other severe medical injuries, they may be unable to conceive children (Brouwer, 2005). This can also have wider sociological implications, as women who are incapable of bearing children can be further stigmatised, due to their failure to fulfil their social role of motherhood (Chinkin, 1994). Other health problems attributed to the transfer of sexually transmitted diseases can dramatically impact on victims lives, especially when victims have limited access to required medication (see Amnesty International, 2004).

Women who bear children to rape face further difficulties. As detailed previously, in relation to Rwanda, some women feel they have no option but to self-abort, often in unsterile and unsafe conditions. This can result in infection, scarring, sterilisation and death (Clifford, 2008). Mothers who carry to full term often reject their children as they are seen as evidence of their 'shameful' experience (Mukangendo, 2007). However, the consequences of such violence are not isolated to SV victims. Children born from rape not only face rejection from their mothers, but also risk being stigmatised by the wider community (see Mukangendo, 2007).

In the wake of SV, women also face other connected consequences related to work, housing and education (see Brouwer, 2005). These difficulties are often intensified as a result of women's subordination and devaluation in society as a whole (McDougall, 1998). However, SV not only affects those personally victimised, but has wider implications for their families, friends and wider communities. It functions to break down the social links that bind society together (Colombini, 2010). After all, rape centred within a community threatens the "well-being and secure existence of the entire community" (Chinkin, 1994: 329). 
Yet, despite the severity and often long lived consequences of SV, it has received minimal recognition within the international legal framework. This contributes further to the suffering of SV victims. As this thesis demonstrates, the opportunity to attain legal justice - via forms of recognition, compensation and other forms of redistributive redress - is markedly limited for most victims. Therefore, it is important that institutional responses to SV work to 'undo' these harms, by recognising, and responding to, the concerns of these victims. In order to evaluate how international legal bodies have secured and/or limited justice opportunities for SV victims, the next section will discuss how justice might be secured by women who have suffered SV.

\section{Sexual Violence Victims and their Pursuit for Justice}

Stanley (2009: 35) recognises that many victims who have suffered human rights violations seek a complex form of justice: one which recognises their suffering, their social needs, as well as one which places them as participants in social mechanisms established to provide redress. Fitting this observation, this chapter will now consider how Fraser's (2007a) model of justice, based on three interlocking dimensions of justice: the socio-cultural dimension of recognition; the economic dimension of distribution; and, the political dimension of representation, might be applied to SV victims. Fraser's (2007a: 20) model is grounded in the assumption that in order to achieve justice, social arrangements need to enable all individuals to participate as "full partners in social interaction". In theory, institutions should be designed and subsequently monitored to ensure that they are delivering justice in a way that benefits all individuals equally (Freeman, 1999).

As above, SV in conflict disproportionately affects females (Baksh \& Etchart, 2005). At the same time, 'status disparities' marked by gender can affect how women go about accessing justice, or making justice claims. Therefore, this section critically engages with Fraser's (2007a) theoretical model in terms of how it relates to gender and gendered injustice. In applying such a restrictive approach, I do not intend to downplay other status disparities, but hope to provide a more informed analysis of how justice might be approached from a gendered point of view. 


\section{Recognition}

Under her socio-cultural based model of justice, Fraser (2007) argues that some individuals are prevented from participating on a par with others due to institutionalised hierarchies and patterns of cultural value. When patterns of socio-cultural value deny requisite standing to particular individuals, they suffer from what Fraser (2007a: 20) referred to as 'misrecognition' or 'status inequality'. Fraser (2007a: 26) understands gender as a status of differentiation that is deeply rooted within the order of society. Within this status order, she argues that gender pervasively shapes socio-cultural patterns of value, which can limit 'participatory parity' in institutions designed to deliver justice. On a societal level, men have held an elite 'status' position over women, because powerful gender ideologies have held women in a subordinated societal position (Charlton, Everett \& Staudt, 1989).

As discussed above, systemic gender discrimination has ensured that women have been denied equal social, economic and political standing in comparison to their male counterparts. Furthermore, gendered hierarchies of cultural worth have helped to sustain social practices, whereby men have exerted power and social control over women, and subsequently devalued them in the process. According to Fraser (2007b), social institutions designed to deliver justice regularly mirror socio-cultural values of worth, meaning women are often regarded as inferior, excluded or are rendered invisible within social interactions. Therefore, the main feature of gendered injustice - in terms of recognition - is androcentrism, which Fraser (2007b: 26) defines as "an institutionalised pattern of cultural value that privileges traits associated with masculinity". Androcentric cultural values impact negatively on women's lives because men's interests take priority.

In support of these contentions, and directly applying them to the focus of international legal justice, Charlesworth, Chinkin \& Wright (1991) argue that because women have been excluded from leadership and important decision making roles in state and international organisations, androcentric thinking has dominated international legal discourse. They applied this contention to the UN human rights treaty system, where men's experiences have become the un-named, universal norm on which human rights are based (Charlesworth et al., 1991). This is highly problematic, as laws which take men's experiences as the norm, will be less likely to adequately protect or recognise the 
experiences of women (Charlesworth \& Gardam, 2000). In this vein, SV has received little recognition within the framework of IHL, because socio-cultural patterns of value have placed men's experiences at the forefront of international legal doctrines.

Coomaraswamy (2005), for example, suggests that because SV has been regarded as a necessary and inevitable consequence of conflict, SV committed against women has been ignored by historians, and by those involved in developing and implementing international legal norms. She argues that patriarchal understandings of SV, as well as the absence or invisibility of women in the international legal system, resulted in SV being neglected (Coomaraswamy, 2005: 58). Similarly, Ni Aolain, Haynes \& Cahn (2011) claim that IHL historically failed to recognise and regulate SV against women in conflict due to the dominance of masculine ideals. In particular, they explain that because conflict was an activity carried out by men, the 'laws of war' were created from the "vista of a soldier's need for ordered rules within which to wage war on behalf of the state" (Ni Aolain et al., 2011: 428). Consequently, women's interests were rarely acknowledged on the basis that conflict was viewed as a 'man's world'.

Seifert (1994) suggests that the silence around SV committed against women in conflict can be attributed to hegemonic power. She contends that "those who hold power have the power to name things" (Seifert, 1994: 67). In other words, because men have held a superior status position in society, they have ultimately been able to define and name experiences and harms in the context of conflict. Therefore, when men have interpreted and defined the experiences of women, they have done so in a manner that has kept their power intact (Seifert, 1994). Consequently, even when SV began to garner increased recognition within IHL, laws pertaining to SV were constructed on masculine values and ideals. For example, the 1949 Geneva Conventions (and their 1977 Additional Protocols I and II) very clearly prohibited rape and sexual assault, and called for the special protection of women in conflict. Article 27 of the Fourth Geneva Convention specifically stated that "women shall be especially protected against any attack on their honour, in particular against rape, enforced prostitution, or any form of indecent assault" (ICRC, 2005: 6). However, SV constituted an attack against a woman's 'honour', as opposed to being classified as a manifestation of violence (Copelon, 1994). Gardam \& Charlesworth (2000: 159) argue that this term 'honour' was "constituted exclusively on the basis of certain sexual attributes, the characterising 
features of which are important to men, namely the chastity and modesty of women". In this respect, socio-cultural patterns of value characterised SV in a way that fundamentally supported masculine interpretations of sex. Entrenching such gendered views on violence has worked to undermine the seriousness of SV committed against women in conflict, and as a result, women have been greatly disadvantaged when claiming the right to justice under international legal doctrines. Therefore, for justice to be delivered fairly, social institutions must recognise how socio-cultural values related to status or identity limit the recognition of subordinated individuals within society (Franke, 2006).

Establishing criminal accountability for human rights violations is important, as publicly acknowledging and condemning rights violations can be the first step towards providing redress for victims (Nowrojee, 2006). For some women, having their experiences acknowledged and validated in a formal justice procedure is an important component required to achieve justice under a recognition-based model. Henry (2009), for example, argues that some victims greatly benefit from speaking out about their experiences, as it can be therapeutic and can alleviate the psychological burden of silence. On this basis, it is important that justice mechanisms consider strategies of recognition that expose rights violations, as well as acknowledging the harm that violence causes to its victims. As discussed above, many women face wide-ranging challenges in the aftermath of SV. In addition to recognising SV victims in the justice process, it is also important that justice institutions proactively respond to the needs of these victims, allowing the next dimension of justice to be introduced.

\section{Redistribution}

Fraser's (2007a) second dimension of justice is founded on the importance of redistribution. She argues that some individuals may have limited access to justice, due to economic structures that deny them the resources they need to participate equally with others. When this occurs, individuals suffer from what Fraser (2007a: 20) calls 'distributive injustice' or 'maldistribution'. She contends that the distribution of material resources needs to be fair, which is difficult given that social arrangements often institutionalise "deprivation, exploitation, and gross disparities in wealth and income...thereby denying some people the means and opportunities to interact with others as peers". However, a distributive model of justice that focuses solely on 
economic injustice will not suffice, as it fails to recognise the full social and institutional context that determines distributive patterns (Young, 1990). Stanley (2009), for example, argues that structural injustice is underpinned by economy, as well as race, gender and other status disparities; all of which limit access to the resources and materials required when making justice claims. Therefore, this section will adopt Stanley's (2009) approach, which details the connections between structural disadvantages (underpinned by socio-cultural values of gender, race and age and so on) and economic injustice, which affects how victims access the necessary resources when making justice claims.

Justice institutions often fail to recognise that SV perpetrated against women in conflict can be inextricably linked to socially constructed power imbalances and culturally defined relationships (Freeman, 1999). This is problematic given that patterns of gendered inequality also locate individuals in positions of structural disadvantage, whereby women are unable to advance justice claims. For example, UN Women (2012) note that women are far more likely than men to be poor, which inhibits their access to food, education, healthcare, employment and control over assets. In this context, gendered socio-cultural values are closely entwined with economic structural forces that determine who has access to social resources and who does not. These social inequalities are only deepened in the aftermath of violence, when SV victims continue to face significant economic, educational, medical and socio-cultural barriers to justice (Bastick, Grimm \& Kunz, 2007).

For example, as previously shown, SV victims often require psychological and medical assistance in order to deal with their harms. Following sexual assault, many women may also be unable to work due to these often debilitating factors. However, existing patterns of social inequality prevent women from attaining access to required resources, such as adequate healthcare. As Brouwer (2005) notes, many SV victims are forced to deal with their trauma, physical injuries and contracted diseases on their own. Consequently, when healthcare, counselling and other such social resources in the aftermath of SV are unavailable, women suffer greatly. Therefore, in order for structural redress to occur, the existing inequalities that affect the path to justice need to be identified. The failure to recognise the needs of certain individuals, such as SV victims, can result in distributive injustice (Fraser, 2007a). 
However, few institutions are equipped to deal with distribution in the form of reparation. In particular, Franke (2006) observes that successful international prosecutions are unlikely to order the transfer of money, power or other resources necessary to overcome violence and suffering. Therefore, even when SV crimes are marked by recognition, which may involve indicting and successfully prosecuting violators, justice is hampered by the failure to address the distributive needs of SV victims. Yet, for 'participatory parity' to be possible, Fraser (2007b) argues that victims must overcome status 'misrecognition', as well as 'maldistribution'.

\section{Representation}

As discussed above, socio-cultural 'misrecognition' (which concerns how individuals are recognised and acknowledged), as well as 'maldistribution' (in relation to structural disadvantage, which subsequently determines how resources are allocated), can inhibit 'participatory parity' in institutions designed to deliver justice. When specifically referring to gender, Reilly (2007: 169) asserts that gender bias often results in "structural, social and economic inequalities...which disproportionately disadvantage women in conflict" and impedes their full and equal political participation in justice mechanisms. Thus, Fraser's (2007a) final notion of justice is concerned with how individuals are represented in political institutions established to deliver justice and adjudicate claims.

Fraser (2007a: 21) notes that under this representational model of justice, political boundaries are established that determine "who is included" and "who is excluded" from those entitled to recognition and structural redress. However, even when individuals are recognised and included in justice proceedings, the established procedures determine the ways in which participants can air their claims (Fraser, 2007a). Consequently, when justice is framed in such a way that excludes individuals from participating on a par with others, either in relation to political boundaries or political procedural rules, those individuals suffer from 'misrepresentation'. In this vein, Fraser (2007a: 21) theorised that two kinds of 'misrepresentation' can occur in the frame of justice: 'misframing' occurs when individuals are excluded from participating in the justice process altogether, whereas 'misrepresentation' occurs when individuals are included in the justice process, but are denied the opportunity to participate on equal terms due to procedural rules and methods. 
Although 'misrepresentation' can occur in isolation from other injustices based on 'misrecognition' or 'maldistribution', the three are generally intertwined (Fraser, 2007a: 21). As established thus far, injustice related to the socio-cultural model of 'misrecognition' and structural (economic, gendered, raced, aged and so on) disadvantage often determines who is capable of advancing justice claims. In other words, individuals who belong to less powerful groups in society are more likely to be 'misrecognised' in justice forums. Patriarchal values, for example, have impeded women from participating in political democratic institutions. The distinction made between the public and private sphere can be used as one example. Due to dominant socio-cultural values, men have dominated the public sphere, thus allowing them to regularly convene in political arenas; whereas women have been confined to the private sphere, where their primary responsibility has been limited to domesticated roles, such as raising children and keeping house (Charlton et al., 1989).

Furthermore, some individuals (due to their status position) are also more likely to face structural disadvantage, which limits their access to necessary resources when pursuing claims to justice. For instance, given the dominant division of labour, women have often struggled to acquire funds to pay for legal representation (Porter, 2007). These preexisting social and economic deprivations discriminate and exclude women from accessing justice from the outset (Ni Aolain et al., 2011). Consequently, both 'misrecognition' and 'maldistribution' can limit participatory parity in terms of 'representation'.

With regard to 'misframing', Reilly (2007) argues that women have been excluded from meaningfully participating in justice institutions dedicated to enforcing human rights. Consequently, when such institutions have implemented and enforced human rights norms, they have often failed to respect, or have been ignored altogether, the interests of women (Reilly, 2007). As discussed above, the lack of recognition that SV has received within IHL has greatly limited the opportunity for SV victims to bring their claims forward. To counteract this issue, it is important that justice institutions recognise the social, economic and political realities of their subjects (Carpenter, 2008).

However, even when women have been included in the claims making processes, 'misrepresentation' has occurred, where political decisions and rules either denied 
women the opportunity to air their claims or worked to invalidate them (Fraser, 2007a). Porter (2007), for example, argues that institutional notions of justice often rely too heavily on rules and procedural processes. She claims that this can work to discount "the social relationships of those affected by injustice...consequently failing to recognise the impact of pain, loss of self-dignity and suffering" of victims participating in justice proceedings (Porter, 2007: 107). Where SV victims are concerned, this becomes especially problematic, as procedural notions of justice can exacerbate pain and suffering. As will be discussed in the following chapter, even when international legal proceedings result in successful convictions, women can be subject to secondary forms of victimisation, as a result of gender insensitive court practices (Franke, 2006). This becomes problematic; as such occurrences can undermine positive practices of recognition. Therefore, if women are to be fairly represented in the justice making process, institutions need to be aware of the socio-cultural norms and structural forces which inhibit participation in justice institutions.

\section{Conclusion}

Upon critically exploring the phenomenon of SV in conflict, in regards to its causes, functions and consequences, this chapter established $\mathrm{SV}$ as a problem that requires recognition in the international legal framework. This chapter outlines that SV in conflict takes many forms and fulfils a range of functions, thus making it a useful and effective 'weapon of warfare'. This chapter notes that females make up the majority of $\mathrm{SV}$ victims, and are commonly targeted as a means to immobilise and humiliate whole communities. Furthermore, this chapter highlights that SV can have long-term physical, psychological and other socially debilitating consequences for its victims. Many victims are forced to deal with the aftermath of SV on their own, due to the shame and stigma attached to such violence. When SV victims reveal their experiences they can be devalued, ostracised and sometimes even blamed for such violence. For that reason, it is important that institutional responses to SV work to undo these harms, by recognising and responding to the needs and expectations of its victims. With this in mind, this chapter introduced Fraser's tripartite model of justice. Fraser (2007a: 21) argues that a holistic approach to justice must address issues of representation, along with distribution and recognition. 


\section{Chapter Three: Securing Justice for Sexual Violence Victims in International Criminal Tribunals}

In addition to exploring the causes, functions and consequences of SV in conflict, the previous chapter introduced Fraser's (2007a) theoretical model based on three important dimensions of justice: (i) recognition, the way socio-cultural patterns impact upon how individuals are recognised in the justice process; (ii) redistribution, the way structural injustices, determined by status disparities, can affect how individuals gain access to resources which enable them to participate on a par with others; and (iii) representation, the way membership and procedural issues determine how individuals can pursue justice claims. This chapter builds on these themes, focusing on how justice can be secured for SV victims in international court processes.

The first ICTs of real significance emerged in the wake of WWII. The Tribunals in Nuremberg and Tokyo established international legal efforts to prosecute and punish those responsible for war-time atrocities. Despite criticism $^{15}$, the significance of these ICTs has been highly acclaimed, as they developed important legal precedents laying down the groundwork for increased recognition and enforcement of IHL ${ }^{16}$ (Futamura, 2008; Weiss \& Daws, 2007). However, due to the Cold War, and also related to the international community's lack of commitment to accountability for international crimes, the enforcement of IHL was deeply limited from the 1950s to the 1990s (Futamura, 2008). Nonetheless, the 1990s saw a resurgence of ICT activity when the UN established the International ad hoc Tribunals in the former Yugoslavia (ICTY) and Rwanda (ICTR) (Weiss \& Daws, 2007). Since then, the UN has established a range of other tribunals (and hybrid courts) in many post-conflict countries, including TimorLeste, Cambodia and Sierra Leone. In the last decade, the International Criminal Court (ICC) has also been established.

\footnotetext{
${ }^{15}$ Perhaps the most significant criticism being that the Nuremburg and Tokyo trials functioned to deliver 'victor's justice'. These ICTs failed to indict and prosecute 'victors' who were also responsible for committing crimes during the war and instead focused on crimes committed by the Axis powers (Futamura, 2008; Peskin, 2008: 214; Zolo, 2009).

${ }^{16}$ Shortly after WWII, the 1949 Geneva Conventions (and their Additional protocols) were brought into force (ICRC, 2010). The UN also created other international legal documents in an effort to develop IHL, which included the 1948 Genocide Convention (Schabas, 2006). In 1950, the UN International Law Commission recognised the principles adopted by the Nuremburg ICT and rendered them as important components of IHL (UN, 2005).
} 
The establishment of an ICT creates the opportunity for a variety of positive opportunities whereby: a detailed record of events can be documented; crimes can be named and defined; key perpetrators can be held legally accountable for their actions; calls for revenge can be dissipated; re-establishing respect for the 'rule of law' can help to deter further violations; international relations can be developed by reinforcing the norms of accountability for violations of IHL; and, fragile democratic institutions can be strengthened (Futamura, 2008; Huyse, 1995; Nowrojee, 2005; Vinjamuri \& Synder, 2004).

However, an increasing body of knowledge has begun to address the gender dynamics of these justice frameworks. Feminists have begun to question whether international justice bodies are capable of adequately addressing and responding to the concerns of women in societies affected by conflict. For justice to be meaningful, it is important that these mechanisms take into consideration the needs, expectations and experiences of victims affected by systematic violence (Lambourne, 2009; Porter, 2007). Therefore, the following sections correlate the findings of feminist research with Fraser's (2007a) tripartite model of justice, to establish how ICTs have functioned to deliver justice to $\mathrm{SV}$ victims. In doing so, this chapter will help to 'set the scene' for how SV crimes, as well as its victims, have been acknowledged in the ICTR crimes process.

\section{Promoting Recognition}

As discussed in Chapter Two, recognition-based justice can play an important role in the acknowledgement and redress of harm for SV victims. While some victims may want to forget their experiences in an attempt to move on with their lives, publicly acknowledging and condemning SV can help restore the dignity and integrity of those who have been victimised. International court mechanisms that condemn SV can be one means by which women may attain formal recognition for harms committed against them (Lambourne, 2009). More specifically, upon defining, prosecuting and punishing SV, ICTs create an opportunity for victims' identities to be formally re-valued through processes of recognition (Fraser, 2007a).

Recognition for SV victims was firmly established with the introduction of the ICTY. This tribunal was the first ICT to "deal exclusively with sexual crimes... rather than 
grouping such offences with killings and similar war crimes as the 'accompanying phenomena' of war" (IWPR, 2005: 1). As previously mentioned, rape was explicitly defined as a 'crime against humanity' for the first time in IHL, under Article 5(g) of the ICTY Statute (ICTY, 2009a: 6). Following the classification of such crimes, the ICTY became the first ICT to successfully enter convictions for SV as torture, sexual enslavement and as a crime against humanity (ICTY, 2012). Since these developments, other ICTs (and international/hybrid courts) have developed specific legal provisions condemning SV, and as a result, have successfully prosecuted such crimes.

In the Special Court for Sierra Leone (SCSL), Article 2(g) of the SCSL Statute explicitly defined sexual slavery, enforced prostitution, forced pregnancy and any other form of SV as crimes against humanity (SCSL, 2000). Due to such explicit legal classifications, the SCSL became the first internationalised court to successfully convict sexual slavery and forced marriage as crimes against humanity (Office of the Prosecutor, 2009). Special SV provisions have also been included in the Statute of the Extraordinary Chambers in the Courts of Cambodia and the Special Panels for Serious Crimes in East Timor (see Sellers, 2007). The Rome Statute of the newly established ICC also explicitly condemns $\mathrm{SV}^{17}$, and considered charges of rape for the first time in the trial of Jean-Pierre Bemba (Smith, 2010).

\section{Inhibiting Recognition}

In addition to promoting recognition-based justice, ICTs also limit and/or undermine positive practices of recognition. ICTs can only hope to deal with a limited number of cases (concerning all violations) due to institutional capabilities. Consequently, perpetrators brought before ICTs are a small proportion of those who have committed serious violations (UN, 2010): meaning that many perpetrators will not be held accountable or punished for their actions. While some SV victims might attain recognition-based justice within formal international legal proceedings, most will not have any personal experience of recognition due to such incapacities. In this respect,

\footnotetext{
17 The Rome Statute of the ICC, Article 7(g) lists rape, sexual slavery, enforced prostitution, forced pregnancy, enforced sterilization, or any other form of SV of comparable gravity as crimes against humanity; Article 8(b) (xxii) also lists these violations as serious violations of the laws and customs applicable in armed conflict; while Article 8(e) (vi) lists these violations as serious violations of the Geneva Conventions (ICC, 2011).
} 
individualised needs and concerns become lost in the broader aims of ICT proceedings. For example, Franke (2006: 819) argues that:

In the context of mass atrocities...tribunals cannot come close to delivering 'perfect justice' by establishing culpability and accountability for all of the actors who caused egregious harm in the past. Instead, the tribunals have to settle for a minority of cases that can be used to establish important precedent, identify important kingpins or masterminds of violence...Witnesses in these cases are invaluable resources in the production of wholesale justice, but the individuals become less important than the larger principles which their testimony helps establish.

In other words, international criminal law functions to fulfil broader aims, such as creating international legal precedent. Consequently, the law can only go so far in providing individualised justice for SV claimants, as well as other victims.

However, even taking into account the fact that ICTs can only deal with a limited number of cases, they have still fallen short of adequately responding to SV within the means of their institutional mandates. For example, many scholars have commented on what they call a 'hierarchy of crimes', where crimes of genocide, murder, extermination and torture have taken precedence over crimes of SV (see Galina, 2010; Levy, 1994; Ni Aolain et al., 2011; Nowrojee, 2005). Part of this can be attributed to time constraints and limited court resources, which results in prosecutors focusing on 'more serious' crimes (Seelinger, Silverberg \& Mejia, 2011). Galina (2012: 16), for example, argues that issues related to time constraints, financial limitations, inexperienced investigators, difficulties in gathering evidence and administrative and technical problems, means that who to indict and on what charge becomes a strategic and politically motivated decision within ICTs.

However, even when SV cases do progress, victims often fail to get recognised. Acknowledging SV in the framework of IHL has been pivotal to the success of recognising its victims in ICT proceedings and bringing their perpetrators to account ${ }^{18}$

\footnotetext{
${ }^{18}$ The Nuremburg and Tokyo Charters both failed to generate distinct and separate qualifications for SV crimes. For example, rape was not mentioned as a crime against humanity (see International Research and Documentation Centre for War Crimes Trials (ICWC), 1945: 2; University of Oslo, 1946: 1). Consequently, the Nuremburg ICT failed to indict and prosecute SV despite evidence indicating that countless numbers of women were raped in Europe throughout WWII (Meir, 2004). The Tokyo ICT, however, managed to successfully prosecute SV as a war crime, under 'inhumane treatment', 'ill treatment' and 'failure to respect family honour and rights' (Brouwer, 2005). Yet, by failing to provide a distinct and separate qualification for SV, such acts became subsidiary human rights abuses that were lumped with other war crimes (Levy, 1994).
} 
(Green, Copelon, Cotter \& Stephens, 1994). However, Franke (2006: 817) criticises that these advances have been more "symbolic than revolutionary in nature". Grewal (2010a: 1) elaborates on this assertion, claiming that the development of law which condemns SV has not changed the "phallocentric core" of international institutions. She argues that international legal justice mechanisms are still dominated by male-centric principles and constructs, which has meant that ICTs have presented some of the same crushing limitations that can be observed in national criminal justice settings ${ }^{19}$. Like domestic courts, ICTs fail to satisfactorily take into account issues pertaining to the reality and seriousness of SV and the respectful treatment of SV victims within court proceedings (Brouwer, 2005: 453). As a result, ICTs have limited opportunities for women to attain recognition-based justice.

Part of the problem rests with the fact that, as a whole, ICTs are not victim based. Haldemann (2008), for example, argues that legal proceedings are primarily used to determine the guilt or innocence of the defendant on trial. International legal proceedings are based on the common law system, where the court operates in an adversarial manner. The adversarial court system is based on the premise of discovering the 'truth', whereby the Prosecution and Defence present their case before a judge or jury (Haldemann, 2008). Within this system, a victim is called forward only to answer questions (Trumbell, 2008). In other words, the victim's role is limited to that of a witness, where they are part of a larger process where the Prosecution and Defence set out to 'prove' a given case (Nowrojee, 2005). Therefore, although providing testimony can alleviate the psychological burden of silence, the kind of 'truth telling' that ICTs allow does not always correspond with what justice entails for victims ${ }^{20}$. Henry (2009) notes that, in many cases, victims only get to tell a small piece of their story, which is often frequently interrupted for the purpose of questioning. Furthermore, the Prosecution and Defence often focus on confirming factual evidence as opposed to

\footnotetext{
19 Feminist scholarship notes that insensitive and demeaning court procedures, such as excessive questioning, methods of cross examination and defamatory rules concerning SV, have worked to devalue women and undermine the seriousness of SV. Domestic courts have also allowed for rape myths to permeate judicial proceedings. Consequently, SV victims have commonly encountered attitudes of insensitivity and disbelief by court and other criminal justice staff officials. These factors, among many others, have meant that many SV victims have suffered secondary-victimisation, which can sometimes equate with the level of harm caused by SV in the first instance. See for example, Jordan $(2001,2011)$ and McDonald \& Tinsley (2011).

${ }^{20}$ Franke (2006) argues that justice for victims involves being given the opportunity to freely share their experiences, followed by the recognition that they are being heard.
} 
letting the victim 'tell all'. Consequently, their testimony can become fragmented and their experiences risk being invalidated. In this regard, some scholars have argued that story telling in legal forums can only take the form of giving legal evidence, and does not operate as a therapeutic outlet for many victims (see Dembour \& Haslam, 2004; Franke, 2006; Lambourne, 2009).

Conveying traumatic experiences can also lead to the marginalisation of storytellers. Within court processes, human suffering is often translated into the language of the law, so that victims' testimonies are "legally digestible" (Stanley, 2009: 61). This can be particularly dehumanising, as victims are required to answer specific questions which are irrelevant to their present troubles, but necessary, in terms of fulfilling the requirements of the law (Dembour \& Haslam, 2004). For example, in cases where 'nonconsent' must be proven in order to fulfil the legal definition of rape, questions can be offensive and humiliating for the victim, and can make them feel as though they are not believed (Brouwer, 2005). For instance, in Kunarac et al., the ICTY Chamber held that the absence of non-consent should be raised, despite the Prosecution having established that rape had been committed under coercive circumstances. In her concluding statement, the Prosecutor noted that the witness was appropriately outraged by the questions she was required to answer in order to fulfil the element of non-consent ${ }^{21}$ [Kunarac et al. Judgement].

International legal frameworks also regularly draw attention to sexist views that present themselves in everyday society. Problematically, sex-stereotyped views are often legitimised and further enhanced in international legal frameworks (Carpenter, 2008). For example, Sharratt's (2011) research discovered that the perceptions of staff members of the ICTY and the War Crimes Court in Bosnia-Herzegovina (BiH) were tainted by high levels of misogyny, biases and rape myth acceptance. Within her study, she conducted a total of 58 in depth interviews with members from these two courts, and encountered views such as:

\footnotetext{
${ }^{21}$ This woman had been held in detention in Foca for 40 days, and was subjected to rape over 150 times during her detention. During trial she was asked many questions, including: "Please, Madam, if over a period of 40 days you have sex with someone, with several individuals, do you really think that is with your own will?" [Kunarac et al Judgement: 2235-2236].
} 
You know what...when I'm assigned to a case involving rape... (Silence) I often have doubts as to whether it actually happened or not - Male Judge, BiH (Sharratt, 2011: 8)

I do not understand the cruelty of the rapes, the mutilations, the markings, the killings. I can see if a group of men were fighting in the bush for weeks, when they come [out], they rape. That I understand - Senior ICTY Judge (Sharratt, 2011: 65)

Informed by such findings, Sharratt (2011) argues that some ICTY and BiH staff have demonstrated little regard for the seriousness of SV, or the context in which such crimes have taken place. As a result, SV victims have been at increased risk of secondary victimisation within court proceedings (also see Askin, 2005; Coomaraswamy, 2005; Franke, 2006; Henry, 2009; Ni Aolain et al., 2011).

Last of all, Franke (2006: 822) argues that at their most sensitive to SV, ICTs recognise women as victims. She contends that within particular legal contexts, the term victim is often deemed necessary in terms of conforming to relevant laws when seeking legal redress. However, upon accepting this term, it is expected that women present their sexual vulnerability in order to be taken seriously. This is greatly detrimental to the character of many women who, despite having being victimised, demonstrate great strength and resourcefulness. Askin (2003: 525) argues that labelling these dynamic survivors as victims fails to accurately portray them and "fully respect, embolden and empower" women as "survivors and enablers". In other words, ICTs stereotype victims upon failing to recognise the complexity of their experiences and their reactions to SV. Therefore, whilst ICTs have created some opportunities for SV victims to attain recognition-based justice, these opportunities are markedly limited, and are commonly undermined through these practices.

\section{Providing Redistribution}

Beyond recognising the identities of SV victims, it is also important that international criminal justice mechanisms recognise and respond to the problems associated with structural redress. As discussed in Chapter Two, structural disadvantages (including economic, raced and gendered disadvantages) can render some individuals more vulnerable to violence than others. Furthermore, structural disadvantages also inhibit how individuals can access justice in the aftermath of violence. 
Given that women are located in a position of structural disadvantage, as a result of their devalued position in society, justice initiatives that respond to women's immediate needs can prove highly advantageous. Many SV victims might benefit from forms of reparation or compensation, which would enable them to have adequate access to healthcare, rehabilitation and support services (Brouwer, 2005). Furthermore, distribution might also be used to address the connected harms related to SV, such as food, education, rent and adequate housing requirements (Brouwer, 2005). This is important given that some women may not be able to fulfil their livelihood as a result of being sexually victimised. Therefore, forms of distribution that address these issues can assist victims in their attempt to put their lives back together. Compensation, in particular, might help with necessary material, medical, psychological, social assistance, and support often required after SV (Brouwer, 2005).

ICTs can provide opportunities for SV victims to attain some redistributive-based justice. The 'Declaration of Basic Principles of Justice for Victims of Crime and Abuse of Power' (General Assembly (GA), 1985) was created to assist governments, and the 'international community', in their efforts to secure justice and provide assistance to victims of IHL. In particular, this Declaration details that governments are obligated to address issues concerned with restitution, compensation and assistance when victims have been subjected to violations of IHL. It proclaims that:

States should consider incorporating into national law norms proscribing abuse of power and providing remedies to victims of such abuses. In particular, such remedies should include restitution and/or compensation, and necessary material, medical, psychological and social assistance and support. (GA, 1985: 5)

In line with these standards, ICTs have created rules of procedure, which seek to make redistributive justice attainable. For example, the ICTY Rules of Procedure and Evidence (Rule 106 and 107, see ICTY, 2009b: 104-105) contains provisions for the restitution of property or proceeds to their rightful owner, and victim compensation. However, ICTs have also responded more directly to SV victim's needs. The ICTY, for example, provides medical and psychological support to victims in the ICTY process through the work of the Victim and Witness Support Section (VWSS) (see Chifflet, 2003). 
For some scholars, redistribution is also connected to undoing harm. In this respect, ICTs have also played a redistributive function, which has allowed for the successful distribution of power. When an individual is harmed by another they are overcome by powerlessness. However, upon formally recognising the 'wrongdoer' and holding them to account, a sense of power and control can be restored to the victim (Haldemann, 2008). Thus by prosecuting and punishing those guilty of violations of IHL, ICTs create the opportunity for shame to be redistributed from victim to perpetrator (Franke, 2006). From these observations, ICTs can be seen to deliver redistribution in some ways. However, as detailed in the following section, distributive-based justice remains fairly limited.

\section{Inhibiting Redistribution}

While ICTs cannot be expected to fulfil all elements of redistribution, they should at the very least be "imbued with the spirit of redistributive justice" (Stanley, 2009: 69). However, this has not been the case, as ICTs have largely failed to address distributive needs of victims. Within her work, Stanley (2009) raises the importance of victim capabilities. She proposes that participation within legal institutions cannot be readily secured by those that do not have the full capability to advance their claims. There are various factors which can affect a victim's capacity to participate in international legal proceedings, such as age, disability, previous experiences, the nature of the crime perpetrated against them, personality and coping skills (International Criminal Law Serious (ICLS), n.d: 13). However, capabilities are also limited due to structural disadvantages (economic, 'raced' and gendered) which operate on a much deeper societal level. Many victims cannot access justice from the outset due to their position of structural disadvantage (Ni Aolain et al., 2011).

Where gendered structural disadvantage is concerned, women are more likely to have limited mobility and a lack of socio-economic resources in the aftermath of conflict (Porter, 2007). Furthermore, they are more likely to have deficits in education, and poor legal literacy, making them less capable of pursuing justice claims (Henry, 2009). These social disadvantages are closely related to the social ordering of society, whereby sociocultural and socio-economic values have determined the way in which society is organised (Fraser, 2007a). Problematically, criminal procedures often exclude the 
female subject upon failing to recognise existing inequalities and societal values that prohibit her participation (Carpenter, 2008). These structural disadvantages are exacerbated in the wake of SV, as affected women can be faced with debilitating physical, psychological, social and economic consequences.

Despite this, international legal systems often focus on addressing civil and political rights, and regularly fail to address economic and social rights in conflict (Arbour, 2007; Ni Aolain et al., 2011; Stanley, 2009). Ni Aolain et al. (2011), for example, contend that international justice mechanisms often fail to capture the full picture of rights violations experienced and suffered by women. Where accountability mechanisms have recognised SV, they often fail to recognise and address the connected harms, such as psychological and physical injury, and other social and economic harms (Ni Aolain et al., 2011). Arbour (2007) also comments on the secondary ranking of social, economic and cultural rights. She argues that there is often resistance to affirming these rights, as protecting them can be burdensome and expensive. This is problematic, given that the protection of these rights can contribute to "the redress and prevention of widespread discrimination", and hence greater justice (Arbour, 2007: 22). After all, victims see these struggles as interconnected (Stanley, 2009).

Although ICTs possess the capacity to engage in compensation (and other forms of redress) for those identified as victims, the evidence thus far indicates that they have limited distributive opportunities. Oosterveld (2005), for example, states that provisions pertaining to Rule 106 and 107 in the ICTY have not been invoked. Furthermore, while compensation issues have been raised within ICTY proceedings, where ICTY judges have requested that the UN create a mechanism that works alongside, but outside the Tribunal to address such concerns, the UN has failed to act on such requests (Zacklin, 2004). Other ICTs have also failed to adequately address compensation issues (see Bassiouni, 2008; Brouwer, 2005: 383-420). Moreover, the needs of SV victims have been addressed by ICTs in VWSS's, yet such support has been limited to their stay at the Tribunal (Chifflet, 2003). In addition, those victims not included in court processes cannot benefit from such services.

For Fraser (2007b), justice must combine an approach that addresses the importance of recognition, as well as redistribution. Failing to address the distributive needs of victims 
can undermine the positive outcome of recognition, especially because there is a close connection between formal recognition and compensation in the form of distribution.

As Haldemann (2008: 729) asserts:

Without some form of monetary compensation, an apology for serious wrongdoing risks being superficial, half-hearted, or meaningless...many individuals will be inclined not to take such apologies seriously. There is, here, the sense that 'talk is cheap'.

Thus, without some form of distribution, positive practices of recognition-based justice risk being undermined.

\section{Promoting and Inhibiting Representation}

International legal justice bodies have inhibited women's representation in many ways. Despite recent attempts to encourage female participation within peace and post-conflict initiatives $^{22}$, international legal institutions still fail to adequately recognise the “significant gender inequalities and biases that limit women's meaningful participation at every stage in post-conflict transition" (Reilly, 2007: 155). Feminist scholarship frequently draws attention to the gendered power imbalance that exists in international institutions, and argues that because women have been excluded from peace-making processes, women's issues remain marginalised or unaccounted for within justice institutions (see Charlesworth et al., 1991; Charlesworth \& Chinkin, 2006; Gardam, 2005; Reilly, 2007).

In this vein, Carpenter (2008) argues that institutions designed to deliver justice have only been accessible to individuals who hold economic, social and political power. As a result, women have been excluded from making justice claims, because they are commonly located in positions of structural disadvantage: as discussed above. However, even when women have been included in the claims making processes, 'misrepresentation' has occurred, where political decisions and rules have denied women the opportunity to air their claims, or have worked to invalidate them (Fraser, 2007a). Porter (2007), for example, argues that institutional notions of justice often rely too heavily on rules and procedural processes that adhere to the law. She claims that this

\footnotetext{
${ }^{22}$ In 2009 a UN SC Resolution affirmed: "the important role of women in the prevention and resolution of conflicts and in peacebuilding, and stressing the importance of their equal participation and full involvement in all efforts for the maintenance and promotion of peace and security, and the need to increase their role in decision-making with regard to conflict prevention and resolution" (SC, 2000a: 7). For a full overview, see Porter (2007: 11-42).
} 
can work to discount the social relationships of those affected by injustice, consequently failing to recognise the impact of pain and loss of self-dignity of victims who participate in justice proceedings. As discussed above, criminal procedures tend to benefit criminal defendants, and the court operates to conform to legal narratives. This has meant that the individualised needs of victims go unrecognised. In addition, victim participation is fairly limited on the basis that they cannot air their claims in the way they desire, or in a manner that is consistent with their understanding of justice.

Closely related to this point, is the notion that ICT proceedings have been dominated by male standards. Ni Aolain (1997: 885) argues that the rules of evidence concerning SV have helped perpetuate "unstated social understandings regarding female and male sexuality”. As discussed above, sex-stereotyped and sex-discriminatory practices are common-place in ICT proceedings. These practices can inhibit participation, especially when rules of evidence allow for such views to be perpetuated in criminal procedures. Feminists have long questioned procedural techniques that allow the Defence to question SV victims in a hostile manner, or introduce 'evidence' influenced by sexbiased attitudes (Reilly, 2007). The most pertinent procedural rule is one which allows a woman's prior sexual history to be examined, supposedly proving her consent to sex by attacking her credibility (Carpenter, 2008). This contention harks back to male-focused interpretations of SV. If a woman is to be considered a true victim, she must prove that she is modest and chaste (Charlesworth \& Gardam, 2000, Green et al., 1994). Although the latter issue has been addressed by the ICTs ${ }^{23}$, serious concerns remain around the conduct of Defence teams, as will be identified in the following chapter. The existence of these procedures is problematic, because if women do not feel safe and are subjected to further trauma, the benefits of participating in justice proceedings offer little to help them in their recovery.

ICTs have made some efforts to provide support and protection to victims, which is important in terms of promoting their participation within justice procedures. For example, the ICTY established a VWSS which allowed for a range of protective

\footnotetext{
${ }^{23}$ Within the ICTY, Rule 96 (VI) of the Rules of Procedure and Evidence states that, "prior sexual conduct of the victim shall not be admitted in evidence" (ICTY, 2009b: 99).
} 
measures to be undertaken ${ }^{24}$. However, although well intentioned, these units have been fairly limited. The processes set in place have not always secured the safety of victims and witnesses. Sharratt (2011), for example, notes that names of victims were often leaked to the press and commonly spoken aloud during ICTY trial proceedings by judges or prosecutors (meaning that the Accused knew the names of victims who had testified in closed circuit). Cases were even reported where lawyers and judges had leaked the names of protected victims to their relatives, which sometimes meant that names were disseminated to the public. This became problematic due to the heavy shame and stigma surrounding SV. When victim's names were leaked, they became vulnerable to harassment and were often stigmatised on their return home.

Stover's (2005) research on the ICTY reveals much the same. He argues that, of the protected witnesses he had interviewed, the majority felt that protection measures had failed and had left them open to recrimination. Other witnesses revealed that protective measures made no difference, as it was well known within their community that they had testified at the Tribunal. Green et al., (1994: 219) note that support for VWSS's has been fairly limited, in terms of staffing, funding and other necessities which are required to allow such programmes to operate effectively.

\section{Conclusion}

Although ICTs have facilitated some justice for SV victims, the opportunities to attain to recognition, redistributive and representative notions of justice have been limited. This chapter highlights that ICTs have facilitated recognition-based justice for SV victims, namely through the development of IHL. However, serious problems remain concerning the ways in which crimes of SV are addressed, and how women are treated within ICT proceedings. Furthermore, although ICTs do offer the opportunity to

24 Rule 75 of the Rules of Procedure and Evidence (ICTY, 2009b: 75) states that the ICTY can undertake:

(i) Measures to prevent disclosure to the public or the media of the identity or whereabouts of a victim or a witness, or of persons related to or associated with a victim or witness by such means as:

A. Expunging names and identifying information from the Tribunal's public records

B. Non-disclosure to the public of any records identifying the victim or witness

C. Giving of testimony through image- or voice- altering devices or closed circuit television

D. Assignment of a pseudonym

(ii) Closed sessions, in accordance with Rule 79

(iii) Appropriate measures to facilitate the testimony of vulnerable victims and witnesses, such as one-way closed circuit television 
administer redistributive justice, clauses related to reparation, compensation and restitution have not been enacted. In addition, while power can be redistributed from perpetrator to victim after obtaining a successful conviction, such practices are limited given that ICTs fail to respond to other redistributive injustices (Fraser, 2007a). Lastly, this chapter notes that while ICTs have undertaken measures to encourage victim participation, particularly upon establishing VWSS's, these efforts have been compromised due to significant operational issues. The next chapter practically applies and expands on these arguments, and considers how justice has been secured for SV victims within the ICTR crimes process. 


\section{Chapter Four: Responding to Sexual Violence in the United Nation's International Criminal Tribunal for Rwanda}

The ICTR was established by the UN's SC on the November $8^{\text {th }}, 1994$ (SC, 1994b). Under its mandate, the Tribunal was given the power to prosecute individuals responsible for serious violations of IHL committed in Rwanda, and in neighbouring states, between January $1^{\text {st }}$ and December $31^{\text {st }}$, 1994 (ICTR, 2010a: 59). The Tribunal hopes to restore peace in Rwanda, contribute to the process of national reconciliation, and deter further violations by re-establishing the 'rule of law' (SC, 1994b).

However, this Tribunal initially focused on prosecuting those responsible for crimes of genocide, murder and torture, meaning that crimes of SV went unaddressed (see Galina, 2010). Part of this neglect can be attributed to the fact that UN investigative reports forwarded to the Tribunal failed to mention SV and those culpable for such acts ${ }^{25}$. It was not until nine months after the genocide, when women started giving birth in unprecedented numbers ${ }^{26}$, that SV was brought to the attention of UN investigations (Charlesworth \& Gardam, 2000). Consequently, unlike the ICTY ${ }^{27}$, the SC Resolution establishing the ICTR failed to mention systematic SV (see SC, 1994b). Nonetheless, the ICTR Statute governing the work of the Tribunal explicitly defined rape as a crime against humanity under Article 3(g), and listed rape, enforced prostitution and any form of indecent assault, as an outrage upon personal dignity under Article 4(e) (ICTR, 2010a: 61). These Articles presented an opportunity for SV victims to seek justice for the harms committed against them.

This chapter presents original documentary research data which was obtained through the critical examination of completed ICTR cases. Of the 43 cases identified, 25 contain references to SV committed against Rwandan women and girls. 23 of these cases were used for this research project (see Appendix I \& II). These cases provide great insight

\footnotetext{
${ }^{25}$ For example, the UN Secretary-General, the Special Rapporteur of the Commission of Human Rights and the Rwandan Commission of Experts failed to mention SV in their first reports to the UN (see SC, 1994c; Degni-Segui, 1994; SC, 1994d; SC, 1994e).

${ }^{26}$ The National Population Office of Rwanda estimated that between 2,000 and 5,000 children were born from rape (Mukangendo, 2007: 40).

${ }^{27}$ The SC resolution establishing the ICTY expressed its grave concern that serious IHL violations had been committed throughout the Balkans, including the organised and systematic rape of women (see SC, 1993: 1).
} 
into how the ICTR has prioritised and responded to SV, as well as the needs of its victims. Research findings are integrated with broader literature to build a nuanced and informed analysis of the Tribunal's failings and successes.

Using Fraser's (2007a) tripartite model of justice as a theoretical backdrop, this chapter critically evaluates the ICTR, in relation to how this Tribunal has responded to SV and its victims. In doing so, this chapter details some of the generic problems faced by the ICTR, which has affected all victims. This chapter is divided into three main sections: the first section highlights how the ICTR has secured recognition for SV victims by recognising the crimes committed against them and holding their perpetrators to account; the second section discusses how the ICTR has limited and undermined positive practices of recognition, due to significant problems with its institutional framework, institutional incapacities, and problems with participation; and, the last section demonstrates how the ICTR has both secured and limited redistribution for SV victims.

As this thesis has demonstrated thus far, Fraser's (2007a) three dimensions of justice share interlocking and similar features. In particular, both 'misrecognition' and 'maldistribution' can limit participatory parity in terms of 'representation', because socio-cultural norms and structural forces inhibit participation in justice institutions. Due to these interconnections, this chapter discusses representative notions of justice under the recognition model of justice, relative to problems with participation. Within this section, structural disadvantages, which are directly related to Fraser's redistributive model of justice, will also be discussed. I have intentionally included these observations here, because criminal procedures often exclude women by failing to recognise the existing structural and social inequalities that prohibit their participation (Carpenter, 2008).

\section{Securing Recognition for Sexual Violence Victims in the ICTR}

The ICTR has been able to provide some level of recognition of SV and its victims (see Appendix I and II). Of the 23 cases that contain references to SV, 19 included SV charges, leading to six successful convictions overall (see Appendix II: Section (i)). Two additional cases included instances where acts of SV underpinned convictions for 
other crimes (see Appendix II: Section (v): Rutaganda and Nahimana et al.). Within these eight cases of conviction, SV acts were successfully prosecuted as crimes against humanity (rape, inhumane acts, persecution and torture), war crimes (rape and other forms of indecent sexual assault) and genocide (see Appendix I).

When charging any act as a crime against humanity, the attack must have been committed as part of a widespread and systematic attack directed against the civilian population $^{28}$. The ICTR found rape to be a crime against humanity in five cases [Akayesu, Bagosora et al., Gacumbitsi, Muhimana and Semanza]. In the genocidal context, most SV acts were committed against Tutsi women and girls. For example, in Bagosora et al., the Chamber found that rape was committed against Tutsi women and girls by the Rwandan Military who, at times, worked in conjunction with the Interahamwe at roadblocks, community centres and churches. These acts were successfully charged as rape as a crime against humanity. The Chamber recognised that "the assailants and the Accused were aware that these attacks formed part of a widespread and systematic attack on racial and political grounds" [Bagosora Judgement: 556]. The ICTR also managed to successfully recognise the rape of Hutu women as rape as a crime against humanity. In Gacumbitsi, for example, a Hutu woman who was married to a Tutsi testified to having been raped. The Chamber acknowledged that "through the woman it was her husband, a Tutsi civilian, who was the target. Thus, the rape was part of a widespread and systematic attack against the Tutsi civilians" [Gacumbitsi Judgement: 56].

SV was also recognised under other categories (listed as crimes against humanity) such as inhumane acts, persecution and torture. For example, forcing women to undress in public and making them march and perform exercises were recognised as inhumane acts

${ }^{28}$ As listed under Article 3 of the ICTR Statute (ICTR, 2010a: 61):

The ICTR shall have the power to prosecute persons responsible for the following crimes when committed as part of a widespread or systematic attack against any civilian population on national, political, ethnic, racial or religious grounds:
(a) Murder;
(b) Extermination;
(c) Enslavement;
(d) Deportation;
(e) Imprisonment;
(f) Torture;
(g) Rape;
(h) Persecution;
(i) Other inhumane acts. 
[Akayesu]; the act of stripping the body of a dead Tutsi woman and then inserting a stick into her vagina was successfully charged as an inhumane act [Niyitegeka]; the rape of a woman was successfully charged as an act of rape and as an act of torture, due to rape being used for a discriminatory purpose [Semanza]; and, the act of inserting a bottle into the Prime Minister's vagina was successfully prosecuted as an inhumane act, as well as an act of persecution, although overturned on appeal due to questions of culpability [Bagosora et al.].

The most profound success of the ICTR, however, was that it became the first ICT to successfully prosecute $\mathrm{SV}$ as a crime of genocide ${ }^{29}$ in the trial of Akayesu (see Appendix II: Section (i): Case 1). In Akayesu, the Chamber ruled that SV can constitute genocide if such acts are committed with the intent to destroy, in whole or in part, a targeted group. Therefore, the Chamber made findings relative to Article 2(b) of the ICTR Statute noting that:

Rape and SV certainly constitute infliction of serious bodily and mental harm on its victims...In light of all the evidence before it, the Chamber is satisfied that the acts of rape and SV...were committed solely against Tutsi women, many of whom were subjected to the worst public humiliation, mutilated, and raped several times, often in public... and often by more than one assailant. These rapes resulted in physical and psychological destruction of Tutsi women, their families and their communities. SV was an integral part of the process of destruction, specifically targeting Tutsi women and specifically contributing to their destruction and to the destruction of the Tutsi group as a whole. [Akayesu Judgement: 174]

It was discovered that many rapes were perpetrated near mass graves, where Tutsi women and girls were taken to be killed. Thus, the Chamber also made findings relative to Article 2(a) of the ICTR Statute, stating that "in most cases, the rapes of Tutsi women...were accompanied by the intent to kill those women" [Judgement: 175]. These decisions increased the substantive jurisprudence of SV crimes in conflict as they recognised, for the first time, that SV can be a constituent act of genocide. Following

\footnotetext{
${ }^{29}$ As listed under Article Two of the ICTR Statute (ICTR, 2010a: 59):

Genocide means any of the following acts committed with the intent to destroy in whole or in part, a national, ethnical, racial or religious group, as such:

(a) Killing members of the group;

(b) Causing serious bodily or mental harm to members of the group;

(c) Deliberately inflicting on the group conditions of life calculated to bring about its physical destruction in whole or in part;

(d) Imposing measure intended to prevent births within the group;

(e) Forcibly transferring children of the group to another group.
} 
Akayesu, SV formed part of a genocide conviction in four other cases [Bagosora et al., Gacumbitsi, Muhimana and Rutaganda], demonstrating that this breakthrough was not a 'one off' success.

In addition to highlighting the psychological pain that SV inflicts on its victims, with specific regard to genocide, the ICTR also recognised the psychological elements of SV more generally. When tasked with defining SV, the Chamber in Akayesu referred to the 'UN Convention against Torture and Other Cruel, Inhumane and Degrading Treatment or Punishment', noting that, like torture, "rape is used for such purposes as intimidation, degradation, humiliation, punishment, control or destruction of a person. Like torture, rape is a violation of personal dignity" [Akayesu Judgement: 65].

These legal decisions have facilitated the quest for justice for SV victims. By successfully indicting, prosecuting and punishing those guilty or responsible for SV, acknowledgment has been brought to select SV victims. Within these judgements, the ICTR has recognised the gravity and seriousness of SV. The genocide conviction entered in Akayesu, in particular, acknowledged SV as an act that can be strategically and systematically employed with the intent to destroy a group. These findings have contributed to the development of IHL, determining how SV and its victims have been recognised in subsequent cases. Furthermore, the ICTR has recognised the severe psychological harm that SV offences have brought to victims, which has worked to validate and acknowledge victims' suffering. Yet, while ICTR processes have resulted in some degree of recognition-based justice, they have also undermined and inhibited such practices in many ways.

\section{Limiting Recognition for Sexual Violence Victims in the ICTR}

The ICTR has established a factual account of what happened during the Rwandan genocide, by recording the testimony of victims and witnesses (Gallimore, 2008). However, this factual record has been criticised for only telling part of the story. The Special Rapporteur on Violence against Women sent to Rwanda argued that there is a great discrepancy "between the reality that women faced during the genocide and the present lack of...invisibility...of SV cases before both the international and national courts" (Coomaraswamy, 1998: 9). Nowrojee (2005) notes that, given the degree of SV 
committed throughout the Rwandan genocide, practically every defendant before the ICTR should be charged and, where appropriate, convicted of SV. Yet in 2004, on the tenth anniversary of the ICTR, a total of 21 judgements had been handed down, with 70 percent of adjudicated cases containing no SV charges. In the 30 percent of cases that included SV charges, only 10 percent resulted in a successful outcome, with the other 20 percent resulting in an acquittal. In real numbers, that meant than only three defendants were held culpable for their role in SV, one of whom was later acquitted on appeal (Nowrojee, 2005: 3). This research reveals similar findings (see Appendix I and II). By March 2012, the ICTR had handed down 43 judgements, with SV charges being laid in 19 of those cases (44 percent). Seven of these cases (16 percent) subsequently dropped SV charges before going to court, with nine cases (21 percent) securing a SV conviction. However, on appeal, three of these convictions were overturned (seven percent), leaving a mere six cases (14 percent) containing SV charges with successful outcomes, on top of an additional two cases (five percent) where acts of SV underpinned convictions for other crimes (totalling 19 percent overall) ${ }^{30}$. Therefore, of the SV cases that made it to trial, almost half resulted in an acquittal.

Although these results show that the record for prosecuting SV crimes has improved since Nowrojee's (2005) report, they reveal that SV charges, and subsequent convictions, are still underrepresented in the ICTR. More importantly, these figures indicate that SV victims are also underrepresented in the ICTR. As a result, many SV victims have been unable to participate on a par with others, and have been denied the opportunity to attain justice. Where SV victims have been included in the ICTR crimes process, the high acquittal rate has been particularly damaging, as victims and their families have been denied recognition because nobody has been held responsible for their experiences ${ }^{31}$. Haffajee (2006) argues that this is problematic because acquittals put on record that SV did not occur, compromising how SV and its victims are viewed at national and international levels. The following sections provide some insight into why these trends are apparent, in addition to detailing how the ICTR has worked to undermine positive practices of recognition.

\footnotetext{
${ }^{30}$ These findings mirror levels of attrition in domestic SV cases (see Triggs, Mossman, Jordan \& Kingi, 2009: 34).

${ }^{31}$ There were eight successful convictions (which includes two cases where SV underpinned convictions for other crimes), in comparison to seven acquittals (which includes SV convictions overturned on appeal).
} 


\section{Institutional Incapacities}

The ICTR has failed to provide recognition for many SV victims due to significant institutional incapacities. As a whole, the success of the ICTR has been hampered due to obstacles associated with its mandate and location ${ }^{32}$, insufficient funding ${ }^{33}$, limited and untrained staff, and a lack of resources ${ }^{34}$ (see Etcheson, 2005: 177; Galina, 2010; Nowrojee, 2005; Oosterveld, 2005). Bergsmo \& Ling (2012) argue that selecting crimes to pursue and the prioritisation of atrocities in ICTs is often strategic and generally attributed to the challenge of practically applying limited resources. In line with this contention, critics of the ICTR have argued that choosing who to indict and on what charge became a strategic decision in the ICTR, where resources were better reserved for 'more serious crimes' such as genocide, murder, extermination and torture (Galina, 2010: 15). In particular, Nowrojee (2005) claims that the ICTR has failed to pursue a consistent prosecution strategy where SV has been given a high priority ${ }^{35}$.

This might be evidenced when examining cases where SV charges are withdrawn in exchange for a guilty plea for other concurrent charges. Balthazar (2006: 48) explains that "rape charges seem to be the first to go". In five of the 23 examined cases, SV charges were dropped by the Prosecutor (see Appendix II: Section (iv) for a full overview). In Nzabirinda and Bisengimana, SV charges were subsequently withdrawn

\footnotetext{
${ }^{32}$ Despite initial support for the establishment of an ICT, Rwanda later voted against SC Resolution 955 for several reasons, including that the period of time in which the Tribunal covered was deemed inadequate, as hostilities began as far back as 1990. The Rwandan Government also opposed the location of the Tribunal, in Arusha, Tanzania (SV, 1994d). This location has meant that it has been less accessible to victims and their families (Gallimore, 2008). Thus, many victims have been unable to learn what happened to their loved ones, share and seek recognition for their personal grievances, or hear acknowledgement for the crimes committed (Lambourne, 2009).

${ }^{33}$ From 1995 to 2011, ICTR spending amounted to approximately US\$1.7 billion (GA, 2011). Some scholars have argued that these appropriations are disproportionate to the success that this Tribunal has achieved. Yet, the ICTR and the ICTY have received greater funding than other ICTs, such as those in Cambodia or Sierra Leone (see Arsanjani \& Reisman, 2005: 402).

${ }^{34}$ Goff (2002: 8) notes that there has a been a severe shortage of technological services and equipment in the ICTR, including computers, technology able to digitise judicial archives, as well as limited access to electronic databases, all of which have hindered the drafting of indictments (also see Haddad, 2011: 119). ${ }^{35}$ Goff (2002), for example, conducted an analysis of trends in SV prosecutions in the ICTR from November 1995 to November 2002. In her study, she noted that the Chief Prosecutor's strategy has impacted on how SV crimes have been pursued and prioritised within the ICTR. During Richard Goldstone's two year term of Chief Prosecutor (1994-1996), not a single indictment containing charges of SV was brought forward, as rape was not regarded as a prosecutorial priority (Haddad, 2011). However, during Louise Arbour's three year term (1996-1999) in this position, the number of Prosecution files containing statements regarding SV significantly increased (Goff, 2002: 5). Yet, Carla De Ponte, the Chief Prosecutor to follow, was heavily criticised for her reluctance to prosecute SV crimes during her four year term (1999-2003) (Nowrojee, 2005; Haddad, 2011; Haffajee, 2006). SV charges included in ICTR indictments dropped from 100 percent in 1999-2000, to 35 percent in 2001-2002 whilst she was in office (Goff, 2000: 7).
} 
after the defendants entered into a plea bargain with the Prosecutor. Similarly, SV charges were dropped in Rugambarara and Serushago because the defendants decided to co-operate with the ICTR, and plead guilty to other charges. In Ndindabahizi, SV charges were also dropped before the defendant went to trial.

In other cases, the Prosecutor failed to bring SV charges forward despite having sufficient evidence. For example, SV charges were not laid in Bikindi (see Appendix II: Section (v): Case 19), Mpambara $^{36}$ (see Appendix II: Section (v): Case 21) or Nahimana et al. (see Appendix II: Section (v): Case 22) despite clear evidence being available. For example, in Nahimana et al., the Prosecutor had ample evidence of SV committed against Tutsi women and girls, yet no charges specifically pertaining to SV were laid. While the Chamber made SV findings regarding Nahimana's conviction for persecution as a crime against humanity (see Appendix II: Section (v): Case 22), the absence of specific SV charges suggests that other crimes took precedence. Consequently, it appears that pursuing SV crimes was not a priority for this Prosecutor.

This research indicates that ICTR prosecutors frequently prosecuted SV with insufficient or inadequate evidence, thus resulting in high acquittal rates for SV crimes. It was often the case that, whilst SV acts were confirmed by the Chamber, there was insufficient or inadequate evidence linking the Accused to the acts. For example, in Mugenzi et al., there was expert testimony of widespread and systematic SV. However, the Chamber ruled that it could not infer knowledge on the part of the defendants of these crimes; subsequently, all were acquitted mid-trial [Mugenzi et al. Judgement]. Furthermore, in Kajelijeli, the Chamber validated the experiences of: Witness GDO, who was stripped and beaten with a club as she watched her six year old handicapped daughter being raped; Witness ACM, a Tutsi woman who was raped by Interahamwe at the side of a roadblock; and, the rape of Witness GDT and GDF [Kajelijeli Judgement: 199-200]. However, the Chamber stated that there was insufficient evidence to link Kajelijeli to the assaults, resulting in his acquittal concerning all SV charges. Similar trends were documented in Bagosora et al., Bikindi, Gacumbitsi and Renzaho. Haddad (2011) notes that these trends might be explained by investigative procedures,

\footnotetext{
${ }^{36}$ In this case, SV allegations were made under the charge of genocide instead.
} 
especially in instances where investigators have struggled to obtain solid legal and evidentiary foundations in SV cases.

For example, Obote-Odora (2005) noted that in the early years of the ICTR, staff received minimal training on how to obtain information about widespread and systematic violations of IHL. Many investigators were not familiar with the legal elements required for crimes they were investigating, and as a result, insufficient evidence was often obtained during investigations. In SV cases, these factors prove particularly debilitating. Ni Aolain et al. (2011) assert that obtaining information about crimes of SV takes a considerable amount of time. Furthermore, the intimate nature of SV makes it particularly difficult for SV victims to share their experiences with investigators. Unfortunately, the ICTs have often failed to address these issues (see Seelinger et al., 2011). Consequently, inexperienced and sometimes insensitive staff have worked to keep to strict time frames, employing investigative methods that have failed to address these concerns. The lack of sensitivity, in particular, has resulted from a dearth of initial resources, including limited female investigators and investigators with little or no experience in investigating SV crimes (Nowrojee, 2004; Oosterveld, 2005). Goff (2002) also notes that the high staff turnover in the ICTR substantially increased the difficulty of recruiting staff specialised in gender issues.

In addition, the Tribunal has worked on the presumption that women do not want to talk about rape. For example, in an interview with HRW, the Deputy Prosecutor of the ICTR explained that "African women don't want to talk about rape... We haven't received any real complaints. It's rare in investigations that women refer to rape" (Nowrojee, 1996: 95). However, Nowrojee (1996) explains that it is not the case that Rwandan women do not want to talk about rape, but rather the processes which the ICTR has employed to collect SV evidence are flawed. Neuffer (2003: 278), for example, argues that:

Many found it off-putting when investigators, mostly white males, roared into the villages in their white UN Jeeps and then treated the survivors with condescension, as if they were stupid rather than traumatised. Taba women simply didn't want to open up to them.

These factors have limited the opportunity for SV victims to secure justice in the ICTR crimes process. 
In many instances, victims and their families have been denied justice as a consequence of defective indictments. Defective indictments can be put down to administrative and judicial errors, where the Prosecution has failed to accurately plead the material facts of the case. This has been particularly problematic, especially when SV cases had been confirmed by the Chamber, along with the perpetrator's involvement, yet legal findings could not be made as it would have been unfair to the Accused ${ }^{37}$. In Muhimana, for example, the rape of Witness $\mathrm{AX}$ was confirmed, but due to the failure of the Prosecution to correctly plead the date that she was raped, her testimony could not be used to support the allegations made in the indictment. The Chamber noted that the Prosecution had failed to provide "the Defence with clear and consistent material facts in support of this allegation" [Judgement: 70]. In this same case, the Chamber also ruled that it could not make legal findings concerning the rape of Evelyn and Tabita, the rape and killing of Therese ${ }^{38}$, the rape of Josephine, the rape of Mukasine and the rape of Witness AQ - due to specific material facts not being pleaded in the indictment. These trends were also noted in Bagosora et al., Bikindi ${ }^{39}$, Renzaho ${ }^{40}$ and Semanza ${ }^{41}$. Administrative errors might be explained by the fact that inexperienced and poorly trained staff were forced to work under strict time constraints.

Failing to appeal unsuccessful outcomes related to SV also limited recognition for SV victims. For example, in Kajelijeli, an unsuccessful rape conviction went unchallenged despite having solid grounds for appeal. The Accused was acquitted of rape and

\footnotetext{
${ }^{37}$ As detailed in the Muhimana Case:
}

The Accused has a statutory right to be promptly informed in detail of the nature of the charges brought against him or her. The Prosecution has an obligation to state the material facts underpinning the charges in the indictment... The Prosecution is expected to know its case before going to trial. If the Prosecution does not plead the material facts in the indictment but includes them in its Pre-Trial Brief or raised them at the trial, it will be difficult for the Defence to investigate the new information before the start of the trial. [Judgement: 80]

\footnotetext{
${ }^{38}$ In this incident, a witness confirmed having seen the Accused, who was accompanied by a group of men, surround this woman. The witness deduced that this woman was raped and murdered because when the men left, she lay on the ground with her throat slit, her skirt torn, and a stick was placed into her genitals. However, despite this evidence, the indictment only referred to her murder, and made no mention of the rape.

${ }^{39}$ Inconsistencies were noted in the indictment; however, it was ruled that this did not affect the Accused in preparing for a defence in regard to the SV allegations.

40 These errors have meant that SV convictions have been overturned on appeal. In Renzaho, for example, the rape of AWO, AWN and AWN's sister were overturned due to the indictment being rendered defective (see Appendix II: Case 8).

${ }^{41}$ The Chamber in Semanza validated the accounts of four prosecution witnesses who had been raped. However, the Chamber could not enter a conviction for rape as a crime against humanity in these instances, due to the vagueness of the allegations in the indictment.
} 
inhumane acts as crimes against humanity by a majority, with one judge dissenting. In cases where judges are dissenting, the likelihood of succeeding on appeal is significantly increased. Dissenting opinions demonstrate that the judges are divided when making a legal judgement (see Lauterpacht, 1996: 66). Judge Ramaroson strongly asserted that there was "substantial and specific and corroborative evidence to sustain that Kajelijeli committed the crime with which he was charged, and that he is responsible for the rapes perpetrated on women" [Kajelijeli Dissenting Opinion: 14]. Despite this, the Prosecution team failed to appeal this acquittal. This might also be the result of prosecutorial focus and limited resources.

Although the Tribunal has claimed that it does not establish a hierarchy of norms [Akayesu Judgement: 122], these examples indicate that SV has been treated as a crime of 'secondary status' in ICTR proceedings (Galina, 2010; Haddad, 2010; Nowrojee, 2005). Due to a lack of prosecutorial attention, which has often been attributed to limited resources and insufficient or poorly trained staff, the ICTR has not adequately responded to SV. Consequently, SV claimants have suffered 'misrecognition'.

\section{Problems with the Institutional Framework}

Further factors, which have limited recognition for SV victims, are attributed to the institutional and cultural framework employed by the ICTR. Nowrojee (2005: 20) criticises that:

Little about the institutional culture of the ICTR places the well-being of the genocide victims and witnesses foremost. They are treated as cogs in the larger machine rather than placed central to the process.

In support of this contention, the following discussion reveals that serious issues have surfaced regarding the conceptualisation of rape. The actus reus (the physical components of the crime that need to be proven) has also been heavily disputed, particularly where elements of consent versus coercion are concerned. The adversarial court process employed by this Tribunal has also been criticised, on the basis that the system does little to recognise the needs of victims. This discussion also demonstrates that the ICTR has sometimes engaged in discriminatory treatment of SV victims by employing practices that are insensitive and inappropriate, and at times, has allowed rape myths and sex-biased attitudes to permeate its cultural framework. These challenges have been greatly detrimental to the success of the ICTR in terms of how this 
Tribunal has provided justice for SV victims. Due to these factors, the ICTR has failed to acknowledge women's suffering in a way that has facilitated their recovery and their efforts to be empowered. As demonstrated below, these practices have worked to 'undo' positive practices of recognition.

\section{Defining Sexual Violence}

Cryer, Friman, Robinson \& Wilmshurst (2010) argue that the ICTR Statute still reflects patriarchal understandings of SV. While rape, enforced prostitution and other humiliating and degrading treatment have been recognised as constituting Grave Breaches Common to the Geneva Convention (and Additional Protocol II), such acts are listed under the category of 'outrages upon personal dignity' (ICTR, 2010a: 61). Cryer et al. (2010) argue that this harks back to masculine supported perceptions of sex that regard rape as a crime against a woman's honour, a contention that was previously explored $^{42}$. Other problems have surfaced in regard to how acts of SV have been prosecuted under the ICTR statute. More specifically, the only act of SV explicitly condemned under Article 3(g) of the ICTR Statute is rape. Although other forms of SV have been successfully prosecuted under other applicable categories listed as crimes against humanity (such as inhumane acts, persecution and torture), Levy (1994) argues that SV should be explicitly defined and condemned under separate and distinct legal categories. Without doing so, these violations run the risk of being regarded as subsidiary, if not inconsequential human rights abuses. For example, in Rutaganda and Nahimana et al., instances of SV underpinned convictions for other crimes (see Appendix II: Section (v): Rutaganda and Nahimana et al.), as opposed to being charged as separate crimes of SV.

This research also indicates that the ICTR has struggled to provide a consistent definition of SV within judicial proceedings. As discussed below, ICTR cases have adopted various SV definitions, which is problematic given that when SV definitions vary between and across cases, not all instances of SV will be equally and fairly considered. Ultimately, differential definitions run the risk of recognising the experiences of some victims, whilst failing to recognise the experiences of others.

\footnotetext{
${ }^{42}$ The ICC Rome Statute has since omitted the word 'honour', instead confirming that "rape, sexual slavery, enforced prostitution, forced pregnancy... enforced sterilization, or any other form of SV constitutes a grave breach of the Geneva Conventions" (ICC, 2011:7).
} 
Furthermore, the changing of these definitions may also effect a change in the requisite actus reus that establishes the crime. Consequently, some SV instances may go unrecognised due to strict legal guidelines and subsequent legal interpretation.

Akayesu was the first case that dealt with SV in the ICTR. As rape had no commonly accepted definition under international criminal law, the Chamber was tasked with defining this act. For reasons that will be explored below, the Chamber defined rape as a:

Physical invasion of a sexual nature, committed on a person under circumstances which are coercive. The Tribunal considers SV, which includes rape, as any act of a sexual nature which is committed on a person under circumstances which are coercive. SV is not limited to physical invasion of the human body and may include acts which do not involve penetration or even physical contact...coercive circumstances need not be evidenced by a show of physical force. Threats, intimidation, extortion and other forms of duress which prey on fear or desperation may constitute coercion, and coercion may be inherent in certain circumstances. [Akayesu Judgement: 165]

This definition was notable for three main reasons. First, this broad definition meant that other forms of SV, not limited to penetration, could be punished and prosecuted as rape. Second, it challenged the mechanical definition of rape that is usually adopted in domestic legal proceedings ${ }^{43}$. Lastly, this definition obviated the need to attach 'consent' or 'lack of consent' as an actus reus to the crime of rape. With regards to the first contention, through broadly defining rape as an invasion of a physical nature, other acts not limited to penetration, such as sexual mutilation, could be punishable by the Chamber [Akayesu Judgement: 165]. Consequently, the Chamber increased the substantive jurisdiction over crimes of rape to include other forms of SV, which created greater opportunities for victims' experiences to be recognised.

Within this definition, the Chamber also recognised that rape was a manifestation of aggression, and that the central elements of this crime could not be "captured in a mechanical description of objects and body parts" [Akayesu Judgement: 165]. In making this finding, the Chamber acknowledged that cultural insensitivities associated

\footnotetext{
${ }^{43}$ In particular, in Akayesu, the Chamber argued that although national jurisdictions had historically defined rape as non-consensual sexual intercourse, focusing on the mechanical nature of rape (relative to the insertion of body parts or other objects), it maintained that such an approach would not suffice in the context of international criminal law.
} 
with discussing intimate details in public, in combination with the painful unwillingness and inability of victims to discuss such graphic anatomical details, made it particularly difficult to conform to such a mechanical approach [Akayesu Judgement: 65]. This decision was perhaps heavily influenced by the evidence heard throughout the Akayesu trial, where the Prosecution and the Defence both tried to obtain explicit mechanical descriptions of what happened in instances where witnesses had applied the term 'rape ${ }^{44}$. These attempts caused great embarrassment and trauma for victims. However, in broadly defining SV, the Chamber challenged the need for SV victims to go into explicit and arguably unnecessary detail.

Lastly, Akayesu adopted a definition of rape that established coercion as a component of the actus reus, rather than consent or lack thereof. ICTs have been heavily criticised for their inclination to adopt definitions of rape from national law that focus on the notion of consent (see Brouwer, 2005; Grewal, 2010b, 75-78; Schomburg \& Peterson, 2007). Brouwer (2005), in particular, asserts that the legal definitions of rape employed by national jurisdictions were not written for the purpose of adjudicating rape claims in IHL. In other words, national definitions of rape founded on principles of consent cannot easily be applied to violations that have formed part of a widespread and systematic attack against civilians in times of conflict ${ }^{45}$. Therefore, Brouwer (2005: 428) argues that establishing a lack of consent for SV crimes is irrelevant within the international legal context, "especially in light of the violent and repressive context in which rapes as genocide, crimes against humanity or war crimes take place". These same contentions have, at times, been expressed within ICTR proceedings, but with little consistency.

\footnotetext{
44 For instance, on the request of the Prosecutor in Akayesu, Witness JJ "with great embarrassment...explicitly specified that the rapist...penetrated her vagina with his penis" [Judgement: 107]. Witness NN during cross-examination also had to clarify what she meant by rape, stating "they took their 'sex' and put it into hers" [Judgement: 111].

${ }^{45}$ In Furundzija, however, the ICTY Chamber noted that when crimes are not defined in international criminal law, national jurisdiction can be used to inform definitions on two conditions. First, the international court cannot rely on just one definition applied within a particular national legal system. Rather, it must consider references made in all national jurisdictions in order to establish common elements of the crime in question. Second, given that international criminal proceedings differ significantly from national criminal proceedings, the application of national legal elements needs to be approached with caution [Furundzija Judgement: 70].
} 
Like Akayesu, the Chamber in Muhimana ${ }^{46}$, Musema and Niyitegeka employed definitions of rape that focused on coercion rather than consent ${ }^{47}$. However, the Chamber in Semanza took a step backwards from this broad definition, choosing to adopt the definition established in the ICTY Chamber, in Kunarac et al. After reviewing national jurisdiction, the Chamber in Kunarac et al. established that rape occurs without the consent of the victim ${ }^{48}$ [see Kunarac et al. Judgement: 155-156]. The Chamber in Semanza concluded that the Kunarac et al. definition was more persuasive, and subsequently noted that "the mental element for rape as a crime against humanity is the intention to effect the prohibited sexual penetration with the knowledge that it occurs without the consent of the victim" [Semanza Judgement: 104]. The inclusion of consent meant that it became part of the actus reus of the crime ${ }^{49}$.

The subsequent confusion on this issue, led the Prosecution, in the Gacumbitsi Appeals Chamber, to seek a clarification of the law pertaining to rape. The Prosecution noted that SV only fell within the Tribunal's jurisdiction when such acts occurred in the context of genocide, armed conflict, or a widespread or systematic attack against a civilian population, "circumstances where genuine consent is impossible" [Gacumbitsi Appeal Judgement: 55]. Consequently, the Prosecution argued that rape should be treated the same as any other violation of IHL, and that these circumstances negate the need for the Prosecution to establish knowledge of a lack of consent in the actus reus. Instead, consent should be considered as an affirmative defence under Rule $96^{50}$

\footnotetext{
46 In Muhimana, the Chamber noted that "circumstances prevailing in most cases charged under international criminal law, as either genocide, crimes against humanity, or war crimes, will be almost universally coercive, thus vitiating true consent" [Muhimana Judgement: 100].

${ }^{47}$ These judgements also argued against including a mechanical description of body parts in the definition of rape, which is relevant due to reasons already discussed.

${ }^{48}$ The ICTY Appeals Chamber justified the inclusion of consent on the basis that there "are factors other than force which would render an act of sexual penetration non-consensual or non-voluntarily on the part of the victim" [Kunarac et al. Appeal Judgement: 39].

49 Furthermore, by applying such a restrictive approach, focused on sexual penetration, the Chamber subsequently limited the possibility of trying other SV crimes as rape However, to its credit it did recognise that other SV acts "may be prosecuted as other crimes against humanity within the jurisdiction of this tribunal such as torture, persecution, enslavement, or other inhumane acts" [Semanza Judgement: 104].

${ }^{50}$ Rule 96 Clause (ii) and (iii) concern issues pertaining to consent and stipulate that:
}

(ii) Consent shall not be allowed as a defence if the victim:

(a) Has been subjected to or threatened with or has had reason to fear violence, duress, detention or psychological oppression; or

(b) Reasonably believed that if the victim did not submit, another might be so subjected, threatened or put in fear. 
[Gacumbitsi Appeal Judgement: 55]. Despite the validity of such contentions, the Chamber deemed it necessary to include non-consent in the actus reus for crimes of rape $^{51}$. The Chamber in Kajelijeli, Renzaho [Judgement: 206] and Kamuhanda [Judgement: 121] also applied this restrictive approach.

Thus, although the burden of proving non-consent in the Akayesu definition was deemed unnecessary by the Chamber, this once dominant definition seems to have been replaced by the definition employed in Kunarac et al. above; a definition which has maintained the necessity of establishing non-consent in the actus reus of the crime of rape. In this respect, it might be argued that SV is not treated on a par with other violations, as these crimes need not establish a lack of consent in order to constitute crimes of IHL. After all, it would be ludicrous to suggest that anyone might consent to torture, let alone genocide, in times of conflict.

Brouwer (2005) argues that rape in conflict almost always takes place in coercive circumstances, which is evidenced by all ICTR and ICTY cases involving rape to date. Furthermore, acts of SV or rape can only be prosecuted as genocide, or as crimes against humanity, if such acts are committed as part of a widespread or systematic attack against a civilian population, indicating the existence of coercion (Brouwer, 2005). Therefore, the inclusion of consent in the legal definition of rape seems completely unwarranted. By detailing that the notion of consent in legal definitions needs to be fulfilled, victims may be subject to painful and humiliating questions regarding consent, which are irrelevant given the circumstances in which these crimes have taken place (Brouwer, 2005). By failing to accurately reflect the reality in which crimes of SV take place, ICTs run the risk of silencing SV victims (Brouwer, 2005), thus limiting their opportunity to attain recognition-based justice.

\section{Problems with the Adversarial Court System}

Mertus' (2004) research reveals that many victims hold the belief that giving testimony to crimes in ICTs will help them move forward with their lives. In particular, many

(iii) Before evidence of the victim's consent is admitted, the accused shall satisfy the Trial Chamber in camera that the evidence is relevant and credible. (ICTR, 2010b: $115)$.

51 The Chamber stated that: "the Prosecution can prove non-consent beyond reasonable doubt by proving the existence of coercive circumstances under which meaningful consent is not possible" [Gacumbitsi Appeal Judgement: 56]. 
victims hope that, upon attaining public recognition for the harms committed against them and bringing their perpetrators to account, they can put their lives back together. However, many victims have been disappointed with the adversarial court process and its ability to deliver justice in a way that meets such expectations (Mertus, 2004). As this research reveals, a lack of sensitivity towards SV and its victims has proven greatly detrimental to ICTR prosecutions. As discussed above, ICTs have sometimes failed to satisfactorily take into account issues pertaining to the reality and seriousness of SV and the respectful treatment of its victims within court proceedings (Brouwer, 2005: 453). Consequently, SV victims have often been subjected to secondary victimisation within the courtroom (Askin, 2005; Coomaraswamy, 2005; Franke, 2006; Henry, 2009; Ni Aolain et al., 2011), which has worked to 'undo' positive practices of recognition.

As previously identified, the way in which ICTs have been structured has worked to silence SV experiences, as well as other victims' experiences. Most notably, adversarial court systems concentrate on affirming 'facts', and as such, can limit the role of the victim. For example, in Kajelijeli, the Chamber heard the testimony of Witness GDO who relayed evidence of the rape and murder of her 15 year old handicapped daughter, along with her own assault (see appendix II: Section (iii): Case 11). While the testimony of this witness was deemed credible insofar as her daughter was raped and killed by Interahamwe, there was reasonable doubt as to whether Kajelijeli was present at the scene due to inconsistencies between the witness's written statements and her trial testimony. In her written statement, she located Kajelijeli a distance of 50 metres from where the crime had been perpetrated, and noted that the crime occurred at 4am. However, on cross-examination she stated that she did not know how to estimate distance in metres, and recalled the assault to have taken place early in the morning ${ }^{52}$. Establishing these sorts of 'facts' can be a difficult process for victims, as it means they are unable to describe their experiences in their own words (Henry, 2009). The focus on literal facts, such as the distance in metres in which the Accused stood, and the time at

\footnotetext{
${ }^{52}$ Combs (2009: 243-246) observes that victims often have difficulties estimating distance, due to a lack of ability, or they are incapable of applying their understanding of distance to western measurement frameworks (such as recording distance in metres). Duration estimates and numerical estimates also prove difficult for victims (Combs, 2009). This is problematic given that accurate accounts of establishing these details are of crucial importance to establishing the 'facts' of a given case. Consequently, legal teams may try and get distances and other factual details through showing maps, pictures or lengths (Combs, 2009). However, this is not always understood by victims, and can undermine a victim's testimony, as in this example.
} 
which the act was perpetrated, restricts the manner in which victims are able to share their stories (Dembour \& Arbour, 2004).

Related to this point is the unnecessary trauma caused to SV victims on having to conform to a mechanical definition of rape (as discussed above). In having to discuss the mechanical nature of rape (describing which body part went where), SV victims become almost invisible in the legal process. Bumiller (2008: 46), for example, asserts that:

The legal definition of rape in the courtroom diminishes her voice in contrast to the overwhelming presence of her body. She is a voiceless form or a mechanical woman. Without the victim's voice, the power of interpretation belongs to the law's vision of sexual crime. The legal filter of relevancy erases her own experiences from a retelling of events that focuses on men's transgression against her body.

For example, in Akayesu, Witness NN recalled how she was brutally raped alongside her sister, after their house was destroyed by their Hutu neighbours. Her father and her brother had been murdered in the process. She explained that her mother had pleaded with the two men, armed with bludgeons and machetes, to kill her and her sister rather than rape them in front of her. One of the men replied that the "principle was to make them suffer", and then she and her sister were raped [Akayesu Judgement: 109]. On cross-examination, Witness NN had to confirm "that the man who raped her penetrated her vagina with his penis", to which she then added that "he did it in an 'atrocious' manner, mocking and taunting her" [Judgement: 110]. Witness NN's testimony is particularly harrowing. However, the Chamber was more focused on establishing the facts, in order to determine whether the crime of rape had been committed. In order to do so, the Chamber had to 'filter' the relevant pieces of information, subsequently choosing to focus on and get her to describe the transgression against her body using explicit reference to 'penis', 'penetration' and 'vagina'. Thus, this witness was also unable to tell her story in her own words; instead her testimony was chopped, refined and made legally digestible, so that it could conform to the legal anti-narrative (Mertus, 2004: 113).

Other problems within the adversarial system (and how it operates) can be located in methods of cross-examination, as well as the conduct of ICT staff. As previously discussed, there have been many problems with ICTs in terms of the evident power 
imbalances between female witnesses and lawyers in the adversarial court system. Henry (2009) acknowledges that this imbalance is often recognised in methods of crossexamination, where Defence lawyers can use manipulative and insensitive crossexamination strategies in determining the credibility of a witness. During the ICTR trial proceedings, SV victims were sometimes asked difficult, unnecessary or inappropriate questions. For example, in Akayesu, several victims were asked questions concerning "where the rapes took place", "how many rapists there were", and "how old they were at the time of the assault" [Akayesu Judgement: 117]. However, the Defence also asked "which rapists used condoms" [Akayesu Judgement: 117]. Such questions seemed unnecessary given that they are irrelevant to establishing that these rapes occurred ${ }^{53}$.

Another example was highlighted in the Butare et al. case ${ }^{54}$. In this case, a woman, who testified to being raped multiple times during the genocide, was asked inappropriate and degrading questions by the Defence, including "did you touch the Accused's penis", "how was it introduced into your vagina", and "were you injured in the process of being raped by nine men"55 (Nowrojee, 2007: 130). To add further disrespect, the Defence implied that she could not have been raped as she had not taken a bath that day, and subsequently smelled, to which the judges burst into laughter (Nowrojee, 2007). This victim later told Nowrojee (2007) that most of her family were killed during the genocide, but she had survived. She expressed that:

To answer the strange questions asked by the ICTR...If you say you were raped that is understandable. How many times do you need to say it? When the judges laughed, they laughed like they could not stop laughing. I was angry and nervous. (Nowrojee, 2007: 130)

This example clearly demonstrates that some ICTR staff members have shown a lack of respect and professionalism. This is not an isolated incident.

\footnotetext{
${ }^{53}$ In 2010, the ICTR amended the Rules of Procedure and Evidence, Rule 90, to include clause (g), which confirmed that "cross-examination shall be limited to the subject-matter of the evidence-in-chief and matters affecting the credibility of the witness and, where the witness is able to give evidence relevant to the case for the cross-examining part, to the subject matter of the case" (ICTR, 2010b: 103).

${ }^{54}$ This case is on appeal, and subsequently not included in the rest of this research. Nonetheless, it is important to acknowledge, given the severe mis-treatment of one particular rape victim by a Defence lawyer, as well as the presiding judges.

55 Peskin (2008: 200) notes that there have been longstanding difficulties associated with the ICTR judiciary, especially in its many failed attempts to "control and hasten" courtroom proceedings. Butare et $a l$. is one example where judges failed in their efforts to caution the Defence in regards to inappropriate questioning. ${ }^{55}$ In 2010, the ICTR amended the Rules of Procedure and Evidence, Rule 90, to include clause (f), which stipulated that the "Chamber shall exercise control over the mode and order of interrogating witnesses and presenting evidence" (ICTR, 2010b: 103).
} 
In Akayesu, although not a SV victim herself, Witness J testified to witnessing her six year old daughter being raped when three Interahamwe came to kill her father. In his closing argument, the Defence lawyer used the example of Witness $\mathrm{J}$ to demonstrate the dishonesty of Prosecution witnesses. The Defence recalled that despite being six months pregnant, the witness was able to climb a tree and stay up the tree all week without food, in "her condition". The Defence went on to characterise the victim's testimony as "fantasy", stating that this "fantasy" is of "interest to psychologists and not justice" [Akayesu Judgement: 118]. The witness challenged his suggestion by stating "if somebody was chasing you, you would be able to climb a tree" [Akayesu Judgement: 118]. Such an insensitive personal attack shows little regard for the victim and the experiences she endured throughout the genocide. These examples demonstrate that, at times, Tribunal staff have behaved in ways which have subjected victims to unnecessary trauma. Due to such factors, Brouwer (2005) argues that in conflict, where rapes are systematic and often strategically adopted, an aggressive common law strategy of crossexamination is not appropriate.

\section{The Institutional Construction of Rape Myths}

This research has also revealed that the ICTR has allowed for stereotypes and rape myths to pervade judicial proceedings. Rape myths are defined as "prejudicial, stereotyped, or false beliefs about rape, rape victims and rapists" (Burt, 1980: 217). Temkin \& Krahe (2008) argue that stereotypical beliefs and attitudes about SV, its victims and its perpetrators, can affect the judgements of individuals who are involved at each stage of the legal decision making process. They assert that the belief in rape myths, and other misconceptions about SV, serves to undermine the seriousness of SV through attributing blame to the victim, while exonerating the perpetrator (Temkin \& Krahe, 2008). Problematically, attitudes and false misconceptions about SV can lead to higher attrition rates (see Bower, Eysell, Pina \& Siebler, 2009), which can limit the possibility for recognition in judicial processes.

Moreover, SV victims are often confronted with disbelief, blame and a lack of empathy due to such stereotypical beliefs (Temkin \& Krahe, 2008). This research identified several rape myths and other sexed stereotypes which were evident in SV cases including: only chaste, virginal women can be true victims of rape; rapists act on uncontrollable sexual urges; pretty or beautiful women invite rape; and, all women 
should be able to resist rape (Bower, Esyell, Pina, Siebler \& Vicki, 2009). These examples will be examined and explored below.

The first myth examined in ICTR proceedings harks back to the traditional belief that only chaste, virginal women warrant legal protection from the law. Wykes \& Welsh (2008) argue that prior sexual history was commonly used in national courts to discredit the testimony of a rape victim, and undermine her right to legal protection ${ }^{56}$. This myth was examined in Rukondo. When prompted on cross-examination, Witness $\mathrm{CHH}$ revealed that she was not sexually active at the time of being raped [Rukondo: 112]. Rule 96 (IV) of the Rules of Procedure and Evidence stipulates that prior sexual conduct of the victim shall not be admitted as evidence or as a defence in trial proceedings (ICTR, 2010b: 115). Yet in this case, the victim's virginity was made explicitly clear. This demonstrates the existence of a double standard, as evidence regarding her lack of prior sexual contact was likely admitted in an effort to validate and support the 'believability' of this crime.

Another myth to pervade ICTR proceedings was the 'pressure cooker' theory of SV, a belief founded on the assumption that rape is the result of men acting out uncontrollable sexual urges and their need to fulfil sexual fantasies (Seifert, 1994). This popular and effective myth has been discredited by studies that have revealed that "rape is not an aggressive manifestation of sexuality, but rather a sexual manifestation of aggression" (Seifert, 1994: 55). Yet, during the Akayesu trial, an expert Defence witness named Matata, expressed his view that:

Rapists were more interested in satisfying their physical needs, that there were spontaneous acts of desire even in the context of killing. Tutsi women, in general, are quite beautiful and that raping them is not necessarily intended to destroy an ethnic group, but rather to have a beautiful woman. [Akayesu Judgement: 113]

Not only did his view seem to suggest that men wished to fulfil their sexual desires and were, thus, driven to rape women as a result of their sexual urges (a view consistent with the 'pressure cooker' theory), but his view might be interpreted to mean that only beautiful women were targeted for rape throughout the genocide. The first view attempts to undermine the seriousness of SV, which is especially problematic given the

\footnotetext{
${ }^{56}$ Such perceptions also hark back to IHL provisions which described rape as an attack on a woman's 'honour', as discussed above. This term was constituted on the basis of certain sexual characteristics which needed protecting, namely the chastity and modesty of women.
} 
wider context in which SV occurred throughout the Rwandan genocide ${ }^{57}$. The latter view seems to support the myth that attractive women provoke rape through their appearance (Hartman \& Jackson, 1994). This is noteworthy, given that this testimony attempts to shift a sense of responsibility to the victim, which, in turn, works to minimise the responsibility of the perpetrator (Temkin \& Krahe, 2008). Problematically, the Chamber failed to mention that such views hold no place in the courtroom.

The last myth examined in ICTR proceedings is related to the theme of resistance. Resistance often caters to 'real rape' stereotypes, particularly when victims have had to explain why they were incapable of resisting sexual assault within legal proceedings. Although courts have modified legal provisions pertaining to rape, obviating the need for the Prosecution to prove a lack of consent through physical resistance ${ }^{58}$, these changes seem to have had little impact on court proceedings (McSherry, 1998). McSherry (1998: 30) argues that the easiest way to prove lack of consent is through establishing that the victim physically resisted the attack. Furthermore, a rape victim is often deemed more credible in court if she physically resists the attack (Temkin \& Krahe, 2008). However, her reasons for not resisting such an attack may be deemed more understandable in the presence of a weapon (see Morash, 2005: 133).

The theme of resistance and, the reasons why victims could not resist, were documented throughout this research. In Kajelijeli, Witness GTD testified that she was taken by Interahamwe to a nearby river where they then pushed her down, spread her legs and began to rape her. According to the judgement:

All these people took their turns inserting their sexual organs in her sexual organ...The Witness could not resist because the Interahamwe were armed, and even if she was armed, the Witness thought a weapon would be useless. [Kajelijeli Judgement: 140].

The presence of weapons was also reported in other instances. Witness JJ "explicitly specified that the rapist, a young man with a long knife, penetrated her vagina with his penis" [Akayesu Judgement: 107]. Furthermore, Mukasine testified that "Muhimana had hit her with the butt of his gun and parted her legs before forcibly raping her"

\footnotetext{
${ }^{57}$ As discussed above, SV formed part of a systematic and widespread attack against women and girls. It was used to humiliate and terrorise them, and in some instances, was strategically and consciously employed as a weapon, to bring about the destruction of the Tutsi as a group.

${ }^{58}$ In Akayesu for example, the Chamber ruled that "coercive circumstances need not be evidenced by show of physical force" [Judgement: 165].
} 
[Muhimana Judgement: 47]. Such information appears to have been presented in order to add greater impact with regards to the believability of the crime, enhance the credibility of the victim and prove their lack of consent. However, the inclusion of such evidence can serve to satisfy the myth that all women are capable of resisting rape, except in cases where perpetrators are armed with a weapon. Furthermore, it serves the belief that if a victim does not resist rape, she has consented to it.

To summarise, problems with the ICTR's institutional framework have seriously compromised the recognition that SV victims have received. As argued throughout, the ICTR has failed to consistently define SV in a way that has adequately captured the reality of this crime, instead choosing to adopt a conceptual framework that focuses on consent as an actus reus. Furthermore, the adversarial system has worked to silence and undermine the testimony of SV victims, through employing methods that have failed to meet their expectations. Most notably, the ICTR has prevented victims from retelling their experiences in their own words. Moreover, at times, ICTR staffs have questioned victims in a hostile and insensitive manner, subjecting them to unnecessary victimisation. The existence of rape myths and other sexed stereotypes has also inhibited practices of recognition. As discussed above, such views function to undermine the seriousness of SV by attributing blame to the victim, in an attempt to exonerate the perpetrator.

\section{Problems with Participation}

In addition to the issues explored above, the ICTR has also presented problems which have inhibited the participation of SV victims. The most significant achievement which has encouraged victim participation in the ICTR, has been the special measures undertaken to ensure the protection of victims and witnesses by establishing a VWSS. This unit was established in July 1995, in an effort to ensure the psychological wellbeing and safety of all victims and witnesses (ICTR, 2012). Witnesses have benefited from a range of special measures including, but not limited to: the use of pseudonyms; non-disclosure of their identity unless required by the defence for trial preparation; image or voice altering devices; the option to testify behind a screen; and the option to testify via closed circuit television (ICLS, n.d: 16). Although well intentioned, the ICTR's VWSS has sometimes been ineffective. For example, Goff (2002) notes that victims and witnesses have still been confronted with harassment, 
intimidation and, in serious instances, attempted murder. In addition, names have been leaked back to Rwanda, meaning that some victims and witnesses have been afraid to return to their homes due to fear of reprisal after their testimony (Brouwer, 2005). Consequently, many SV victims interviewed by the Special Rapporteur expressed that they did not have confidence in the protection scheme and, therefore, chose not to use their services (Coomaraswamy, 1998).

Furthermore, Nowrojee (2005) argues that the ICTR has failed to address concerns of post-trial protection. She notes that there is little follow-up to ensure that witnesses are safe and protected after the trial is complete. Post-trial protection is often viewed as a responsibility to be undertaken by national governments, not an issue for ICTs. However, these issues are rarely addressed by national governments. Nowrojee (2005) suggests that there needs to be coordinated effort between ICTs and national governments to ensure that victims can benefit from post-trial protection. Without the guarantee of post-trial protection, victims may be discouraged from coming forward to give testimony, which can limit the opportunity to attain recognition-based justice. These factors are problematic because, if victims feel they are unsafe, they will be reluctant to participate in judicial processes ${ }^{59}$.

The ICTR also has no process to deal with the shame and stigma that SV brings to victims. The difficulties associated with disclosing information about SV has significantly limited participation, or willingness to participate. Perhaps the biggest issue is related to deeply entrenched stereotypes that exist within wider society. For example, the Fourth Annual Report of the ICTR indicates that investigative teams interviewed $360 \mathrm{SV}$ victims in 1998, yet only 85 witness statements were taken as evidence (SC, 1999: 13). These figures may indicate that women are reluctant to testify in the ICTR due to the fear that they will be rejected and stigmatised by their family, as and the wider community (Goff, 2002). However, as argued above, this may also be indicative of poor training and skills of staff employed to investigate SV crimes. Brouwer (2005) details that name leaking in the ICTR has proven problematic in this respect, especially when the names of SV victims have been leaked in Rwanda. She recalls one example, where a woman's fiancé left her after discovering that she was a

\footnotetext{
${ }^{59}$ For a full and comprehensive overview of the Protection and Safety measures undertaken by the ICTR, see Mahony (2010: 59-76).
} 
SV victim who had testified in Arusha ${ }^{60}$ (Brouwer, 2005: 255). These factors are strong deterrents against participating in the ICTR crimes process, thus limiting opportunities to attain recognition.

As identified in Chapter Three, existing social and economic deprivations can also exclude minority groups from participating in justice institutions from the outset, as disadvantaged individuals do not have the means to freely participate (Ni Aolain et al., 2011). Structural disadvantages suffered by women have limited how SV victims have been represented in the ICTR crimes process. In the Rwandan context, structural disadvantage underpinned by socio-cultural values of gender has proven debilitating for women seeking recognition-based justice. Before the genocide, African Unity (2000: 161) described Rwanda as a patriarchal society, where the unwritten laws of Rwandan custom and tradition regarded women as "second class citizens". Like patterns of inequality identified on a global scale, Rwandan women are disadvantaged by social, political and economic forces, subsequently limiting their role in everyday society (see Newbury \& Baldwin, 2000).

The literature demonstrates that these structural disadvantages have only been exacerbated in the aftermath of genocide. Following the genocide, all Rwandans, particularly women, were faced with severe social, political and economic challenges (Newbury \& Baldwin, 2000). Many families went without food, healthcare, education and housing ${ }^{61}$, placing a large burden on women who were left to care for their children, as well as distant relatives who survived the genocide. Goff (2007) argues that SV victims have required immediate socio-economic assistance in order to ensure their survival, and these needs have taken primary importance over attaining legal justice and recognition for the harms committed against them. Henry (2009: 120) bluntly states that many victims are "investing energy into survival and economic stability with little regard to the relative 'luxury' of legal justice". However, even when victims have considered legal justice a priority, the location of the Tribunal proved problematic as possible witnesses were unable to testify due to work commitments. Some witnesses

\footnotetext{
${ }^{60}$ Sharratt's (2011) research, however, reveals that male family relatives have usually supported their female family members in their pursuit for justice.

${ }^{61}$ Inheritance laws in Rwanda saw that women could not gain access to property or land unless they were explicitly designated as a beneficiary of the estate. This meant that many women had no legal claim to the land or bank accounts of their murdered husbands or relatives (African Unity, 2000)
} 
had no option but to pull out of their pursuit for justice, especially given that the Tribunal did not offer expenses (Obote-Odora, 2005).

To conclude, by employing special measures that have worked to protect and support witnesses and victims, the ICTR has assisted some SV victims in their quest for justice. However, these measures have been fairly limited and have not always counteracted the problems which prohibited participation in the first place. Furthermore, due to significant structural disadvantages, many victims have been unable to participate in ICTR proceedings, meaning that they have had no personal experience of 'truth' and acknowledgement.

\section{Securing and Limiting Redistributive Justice}

As already established, ICTs have largely failed to recognise issues concerned with redistributive justice. Drawing on previous observations, this discussion of redistributive justice will focus on practices of reparation. After all, forms of reparation are concerned with issues of restitution, compensation and satisfaction (Gillard, 2003). ICTs can play an important part in satisfactory reparation, especially when harms are formally recognised and acknowledged by the courts. This process of recognition can facilitate the redistribution of power by redefining power imbalances evident between perpetrator and victim. The ICTR has offered some level of satisfactory reparation where SV is concerned, by successfully indicting, prosecuting and punishing those guilty or responsible for such acts. Yet, the potential to 'do' redistributive justice in this sense has sometimes been undermined, especially when victims have felt re-victimised by the courts, or where 'insufficient' sentences have been handed to SV perpetrators ${ }^{62}$.

In light of other forms of reparation, the ICTR has failed to adequately respond to victims' needs where restitution and compensation are concerned (see African Rights \& Redress, 2011). Restitution, as defined by the UN (2010: 40, 47), is "the reestablishment of the situation before the wrongful act was committed", whereas compensation is defined as "economically accessible damage". Gillard (2003) notes that these forms of reparation can be a practical and important part of addressing the consequences that IHL violations cause to victims. As identified in Chapter One, in the

\footnotetext{
${ }^{62}$ See Brouwer (2005: 443-447), Nowrojee (2005) and Seelinger et al. (2011: 52-54) for an overview on sentencing practices in the ICTR.
} 
wake of SV violations committed in Rwanda, victims required urgent medical and psychological care. Women were also faced significant economic burdens due to the loss of property and assets. Many women lost their main source of income, following the deaths of their husbands. These difficulties were further intensified, because many women were unable to work following SV. However, due to institutional limits, as well as a lack of institutional resources, many SV victims have been forced to cope with these challenges on their own (Porter, 2007).

While the ICTR has provided medical and psychological support to victims who have testified, this support has been limited to their stay at the Tribunal (see Brouwer, 2005; Chifflet, 2003). Moreover, such support does not reach those victims who stand outside the ICTR crimes process (Brouwer, 2005). Thus, calls for the UN to address the need of compensation and restitution have been pressed by non-governmental organisations, and other organisations working with genocide survivors (see African Rights \& Redress, 2011). These requests, however, have also been made by the ICTR. In 2002, the then President of the ICTR, Navanethem Pillay, noted that "compensation for victims is essential if Rwanda is to recover from the genocidal experience" (Pillay, 2002: 1). She submitted a proposal to the UN Secretary-General in 2000, which argued that genocide victims should be compensated (Pillay, 2002). Within this proposal she referred to the 'Declaration of Basic Principles of Justice for Victims of Crime and Abuse of Power', as discussed in the previous chapter, which states that victims of wrongful acts should be entitled to restitution, compensation and other forms of assistance for the injuries they have suffered (see GA, 1985). In acknowledgment of this report, the ICTR Judges indicated their support for compensation, but argued that compensation and restitution were issues that should be addressed by domestic courts (SC, 2000b).

This attitude has governed how the ICTR has addressed issues of compensation and restitution. Within the ICTR Rules of Evidence and Procedure, Rule 105 and 106 pertain to principles of restitution and compensation (ICTR, 2010b). In particular, Rule 106 stipulates that victims seeking compensation against a perpetrator convicted by the ICTR must apply to a national court or other competent body in order to pursue claims of compensation (ICTR, 2010b: 121). However, Survivor's Fund (2012) argues that, due to a lack of funds, Rwandan courts have not paid any compensation. Despite this, 
no changes have been made to assist survivors in obtaining compensation within the ICTR framework (Survivors Fund, 2012).

A senior staff member of Ibuka, an umbrella organisation for survivor organisations in Rwanda, details that "the ICTR spends the equivalent of $\$ 500,000$ (US) each year, but we do not see any corresponding gains for the survivors who are seeking justice" (cited in African Rights \& Redress, 2008: 57). In this respect, it might be questioned if the money injected into the ICTR would be better reserved for responding to the immediate needs and challenges that all rights violations victims face in the aftermath of systematic violence.

\section{Conclusion}

This chapter argues that, whilst the ICTR has recognised SV and its victims by successfully indicting, prosecuting and punishing some perpetrators responsible for these heinous acts, SV crimes have often been constructed and responded to in ad hoc and skewed ways. This chapter details that, in the early years of the ICTR, SV crimes went largely unrecognised and unaccounted for. Due to institutional incapacities, in combination with a lack of political will, the Tribunal reserved its time and resources for the investigation and prosecution of 'more serious' crimes, such as murder, torture, extermination and genocide. Although there has been some improvement, this chapter revealed that SV and its victims are still largely underrepresented in the ICTR crimes process. As demonstrated above, the number of indictments containing SV charges is still relatively low. Furthermore, in cases where SV charges have been successfully included in indictments, almost half have resulted in an acquittal.

This chapter also details that there were significant problems concerning the institutional framework of the ICTR. This chapter demonstrates that the ICTR has conceptualised crimes of SV in a skewed way, adopting definitions which have inadequately captured the reality and lived experiences of SV victims. The adversarial court process has also limited victim participation and has functioned to silence and marginalise victims' testimonies in favour of a legal narrative. Not only this, but methods of cross examination have also proved problematic, especially when Tribunal staff have exercised little regard for victims providing testimony, by asking unnecessary 
and difficult questions, and making insensitive and inappropriate remarks in trial proceedings. At times, sex-biased and harmful stereotypes have also permeated the cultural framework of the ICTR. These practices have subsequently undermined positive practices of recognition by subjecting women to unwarranted and unnecessary victimisation.

Victim participation in the ICTR has also been fairly limited, for a number of reasons, including weak and ineffective safety and protection sections, as well as significant structural disadvantages. Last of all, this chapter highlights that the successes of the ICTR in providing recognition for some victims, have been undermined by their failure to address issues concerned with redistribution, particularly in the form of compensation. 


\section{Chapter Five: Conclusion}

Although SV committed during conflict affects men, women and children, it disproportionately affects women and girls. Upon recognising this, Chapter Two argued that SV committed against women and girls can be linked to global systemic patterns of gender discrimination. In particular, this chapter highlighted that the development of socio-cultural values has worked to sustain the dominant gendered social order. Violence against women can be regarded as an extension of such norms and ideologies, which have worked to keep women subordinated within society. At the same time, 'status disparities' marked by gender have affected how women have accessed justice, or made justice claims within international legal institutions. More specifically, these institutions have mirrored socio-cultural norms that have regarded women as unimportant, subsequently excluding them, or rendering them invisible within social interactions (Fraser, 2007b). Due to the male-centric construction of international institutions, SV during conflict failed to garner legal recognition until the 1990s. Consequently, most SV acts committed against women during conflict went unrecognised and unpunished in international legal proceedings.

Nonetheless, the UN acknowledged SV committed against women as a serious concern following the SV atrocities that were widely documented throughout the former Yugoslavia. Following its establishment of the ICTY, the first ever ICT to deal exclusively with SV crimes, the UN has continued to develop and strengthen principles of IHL condemning the practice of SV in other established ICTs. In doing so, the UN has created new opportunities for women to attain justice within international legal justice institutions. However, for justice to be meaningful, these institutions must adequately address the needs, expectations and experiences of those affected by repressive violence (Lambourne, 2009; Porter, 2007). Recognising the importance of such contentions, this thesis employed Nancy Fraser's (2007a) theoretical model based on recognition, redistributive and representative notions of justice, and considered how justice has been secured for SV victims in ICTs. Although the nature of this research skewed the research findings in favour of how ICTs have secured recognition-based justice, issues associated with redistribution and representation were also considered important. 
This thesis has shown that, although SV crimes have been defined and criminalised under IHL, allowing for some level of recognition for SV victims within ICTs, the male-centred core of these institutions has remained intact. In particular, operational issues apparent within these Tribunals have worked to limit and undermine positive practices of recognition-based justice. Due to institutional incapacities, ICTs cannot, and do not, prosecute all SV cases where evidence exists (UN, 2010). However, one might expect that SV crimes would still be rigorously pursued and treated on a par with other rights violations. Yet, research demonstrates that SV cases, and SV victims, are underrepresented in ICT processes. In particular, these institutions demonstrate a lack of political will in their efforts to rigorously investigate and prosecute SV within international legal proceedings. Instead, ICTs have been primarily focused on prosecuting more 'serious crimes', such as genocide, murder and torture (Galina, 2010; Nowrojee, 2005). Furthermore, ICTs have perpetuated sex-stereotyped views and have allowed for discriminatory practices against women to occur. The adversarial court system has also proved problematic, as SV victims, along with victims generally, are not considered central to court processes. They have instead been treated as "cogs in the larger machine" (Nowrojee, 2005: 20).

ICTs have also failed to address concerns of redistribution. In particular, ICTs have failed to address victims' needs in relation to reparation, compensation and restitution, which has prolonged and reinforced their suffering. Stanley (2009) indicates that victims regard recognition and redistributive justice as interconnected. On this premise, without measures that address redistributive injustices, the success of international mechanisms is seriously compromised. As this thesis demonstrates, SV victims face many debilitating physical, psychological and socio-economic consequences in the wake of their violation. The failure to redress and respond to these needs has meant that SV victims have been further disadvantaged. Furthermore, while ICTs have encouraged the participation of victims within ICT proceedings, particularly upon establishing protection and support units, these efforts have been limited and largely ineffective.

Chapter Four consolidated these contentions, presenting the research findings obtained from the critical examination of ICTR cases concerning SV. The analysis demonstrated that while the ICTR has facilitated SV victims in their quest for recognition-based justice by successfully defining, prosecuting and punishing some individuals guilty of 
SV, SV crimes have been constructed and responded to in ad hoc and skewed ways. Hampered by institutional factors including limited and untrained staff, insufficient resources, and strict time frames, the ICTR closed down opport unities for SV victims to attain recognition-based justice. In particular, the number of SV cases processed by the ICTR failed to adequately capture the reality of SV suffered by women and girls throughout the Rwandan genocide. This research revealed that just under half of all SV cases pursued resulted in an unsuccessful outcome, leaving a meagre six successful outcomes.

Furthermore, this analysis showed that problems with the ICTR's institutional framework limited and undermined positive practices of recognition. The conceptualisation of SV, particularly when it has been founded on the burden of proving non-consent, has meant that SV victims have been exposed to unnecessary trauma. In response, scholars like Brouwer (2005), have vehemently argued against such conceptualisations on the basis that they do not adequately capture the reality in which SV has occurred. In addition, some tribunal staff in the ICTR have engaged in hostile and insensitive treatment of SV victims, especially in regard to strategies of questioning and the collation of evidence. The findings reveal that the ICTR has also allowed for rape myths and sex-discriminatory views to permeate judicial proceedings, which have often remained unchallenged by the Chamber. This has proved problematic, as such practices have undermined the seriousness of SV, and worked to wrongfully shame and re-victimise SV victims who have testified (Askin, 2005). Moreover, the limits of the adversarial court system have denied women the opportunity to express their experiences in 'their own words', translating their suffering into the language of the law. Therefore, while the ICTR may have facilitated some recognition of SV victims, it has failed to build an organisational and cultural framework where SV has been appropriately addressed and rigorously prosecuted. The outcomes of cases tend to be the result of individual prosecutorial decision-making, rather than a structured response to SV.

The analysis also reveals that the ICTR failed to adequately address concerns of representation. In particular, the processes designed to provide support and protection of victims has been markedly limited, as treatment and protection schemes only address the needs of those included in the claims making process, and only benefit such 
individuals during their stay at the Tribunal. The ICTR also failed to address redistributive concerns, meaning that most victims who have participated within the justice process have felt that the ICTR failed to offer them an adequate remedy. While recognition can be useful in restoring a victim's dignity and acknowledging the harm caused, such a response seems superficial without the appropriate means required to address physical, psychological and socio-economic injustices connected to their suffering.

To conclude, SV committed during conflict carries myriad functions, and has wideranging and long suffered consequences for its victims. Therefore, it is important that international justice institutions work to respond to this issue, and consider the best way to promote justice that enables victims to overcome these injustices. As it stands, SV victims are now 'on the radar' of the UN. In recognising the gendered nature of SV committed in conflict (BDPA, 1995), the UN challenged the cultural acceptability of violence against women. Furthermore, the UN has begun to build a more progressive discourse towards this group through the development of IHL, which has significantly increased the opportunity for women to attain legal justice within international legal settings. However, this thesis affirms that there is still significant work to do, in terms of changing the cultural and operational nature of ICTs, in an effort to facilitate more just outcomes for SV victims. Strategies such as mandatory gender training, the appointment of specialised and experienced SV consultants, and strengthening protection and support units, are some measures that might be undertaken in an effort to encourage women's equal recognition and representation. Furthermore, upon addressing the evident deficiencies that remain in international legal doctrines, ICTs can ensure that SV crimes are treated on a par with other rights violations, subsequently safe-guarding victims from further and unnecessary victimisation. However, more generalised efforts focused on addressing redistributive injustices, such as supporting SV victims in their plight for reparation, compensation and restitution, would benefit the immediate needs of those so greatly affected by systematic violence. 


\section{References}

African Rights. (1995). Rwanda: Death, Despair and Deviance. London: African Rights.

African Rights \& Redress. (2008). Survivors and Post-Genocide Justice in Rwanda: Their Experiences, Perspectives and Hopes. Retrieved from: http://www.redress.org/downloads/publications/Rwanda\%20Survivors\%2031\% 200ct\%2008.pdf. 19 January 2012.

African Rights \& Redress. (2011). Access to Reparation to Survivors of the 1994 Genocide in Rwandar from: http://www.redress.org/downloads/17August2011 Torture Survivors Conferen ce_BackgroundNote.pdf. 12 September 2012.

African Unity. (2000). Rwanda: The Preventable Genocide. Retrieved from: www.africa-union.org/official.../report_rowanda_genocide.pdf. 12 December 2011.

Amnesty International. (2004). Rwanda: “Marked for Death”, Rape Survivors Living with HIV/AIDS in Rwanda. Retrieved from: http://www.unhcr.org/refworld/docid/4129fd524.htm. 12 July 2012.

Arbour, L. (2007). Economic and Social Justice for Societies in Transition. International Law and Politics, 40(1), 1-27.

Arsanjani, M. \& Reisman, M. (2005). The Law in Action of the ICC. The American Journal of International Law, 99(2), 385-403.

Askin, K. (2003). The Quest for Post-Conflict Gender Justice. Columbia Journal of Transnational Law, 41, 508-521.

Askin, K. (2005). The Jurisprudence of International War Crimes Tribunals: Securing Gender Justice for Some Survivor's. In D. Durham \& T. Gurd (Eds.), Listening 
to the Silences: Women and War (pp. 125-155). Boston: Martinus Nihoff Publishers.

Atkinson, P. \& Coffey, A. (2004). Analysing Documentary Realities. In D. Silverman (Ed.), Qualitative Research: Theory, Method and Practice (2 ${ }^{\text {nd }}$ ed.) (pp. 56-75). London: Sage Publications Inc.

Baaz, M. \& Stern, M. (2009). Why do Soldiers Rape? Masculinity, Violence, and Sexuality in the Armed Forces in the Congo (DRC). International Studies Quarterly, 53, 495-518.

Baldi, G. \& MacKenzie, M. (2007). Silent Identities: Children Born of War in Sierra Leone. In R. Carpenter (Ed.), Born of War: Protecting Children of SV Survivors in Conflict Zones (pp. 40-53). USA: Kumarian Press.

Balthazar, S. (2006). Gender Crimes and the ICTs. Gonzaga Journal of International Law, 10(1), 43-18.

Barnett, M. \& Finnemore, M. (2007). Political Approaches. In W. Daws (Ed.), The Oxford Handbook on the UN (pp. 41- 57). Oxford: Oxford University Press.

Bassiouni, C. (2008). International Criminal Law, Volume III: International Enforcement. The Netherlands: Martinus Nijhoff Publishers.

Bastick, M., Grimm, K. \& Kunz, R. (2007). SV in Armed Conflict: Global Overview and Implications for the Security Sector. Geneva: SRO Kundig.

BDPA. (1995). The Beijing Declaration and Platform for Action: Fourth World Conference on Women. Retrieved from: http://www.unesco.org/education/information/nfsunesco/pdf/BEIJIN E.PDF. 10 June 2012.

Bergsmo, M. \& ling, W. (2012). Towards Rational Thematic Prosecution and the Challenge of International Sex Crimes. In M. Bergsmo (Ed.), Thematic 
Prosecution of International Sex Crimes (pp. 1-11). Beijing: Torkel Opsahl Academic Publishers.

Bower, G., Eysell, F., Pina, A., Siebler, F., \& Viki, G. T. (2009). Rape Myth Acceptance: Cognitive, Affective, and Behavioural Effects of Beliefs that Blame the Victim and Exonerate the Perpetrator. In M. Horvath \& J. Brown (Eds.), Rape: Challenging Contemporary Thinking (pp. 17-45). Cullompton: Willan Publishing.

Brouwer, A. (2005). Supranational Criminal Prosecution of SV: The ICC and the Practice of the ICTY and the ICTR. Oxford: Intersentia.

Brownmiller, S. (1975). Against Our Will: Men, Women and Rape. Great Britain: Richard Clay (The Chaucer Press) Ltd.

Bumiller, K. (2008). In an Abusive State: How Neoliberalism Appropriated the Feminist Movement Against SV. USA: Duke University Press.

Burt, M. (1980). Cultural Myths and Supports for Rape. Journal of Personality and Social Psychology, 38, 217-230.

Cairns, E. (1997). A Safer Future: Reducing the Human Cost of War. Oxford: Oxfam Publications.

Carlsson, I., Sung-Joo, H. \& Kupolati, R. (1999). Report of the Independent Inquiry into the Actions of the UN During the 1994 Genocide. UN doc, S/1999/1257, 16 December 1999.

Carpenter, M. (2008). Bare Justice: A Feminist Theory of Justice and Its Potential Application to Crimes of SV in Post-Genocide Rwanda. Creighton Law Review, $41,595-660$.

Charlesworth, H. \& Chinkin, C. (2006). Building Women into Peace: the International Legal Framework. Third World Quarterly, 27(5), 937-957. 
Charlesworth, H., Chinkin, C. \& Wright, S. (1991). Feminist Approaches to International Law. The American Journal of International Law, 85, 613-645.

Charlesworth, H. \& Gardam, J. (2000). Protection of Women in Armed Conflict. Human Rights Quarterly, 22, 148-166.

Charlton, S., Everett, S. \& Staudt, K. (1989). Women, the State, and Development. New York: State University of New York Press.

Chifflet, P. (2003). The Role and Status of the Victim. In G. Boas\& W. Schabas (Eds.), International Criminal Law Developments in Case Law of the ICTY (75-111). The Netherlands: Koninklike Brill NV.

Chinkin, C. (1994). Rape and Sexual Abuse of Women in International Law. European Journal of International Law, 5, 326-341.

Clifford, C. (2008). Rape as a Weapon of War and its Long-term Effects on Victims and Society. Retrieved from: http://ts-si.org/files/BMJCliffordPaper.pdf. 2 February 2012.

Colombini, M. (2002). Gender-Based and SV against Women During Armed Conflict. Journal of Health Management, 4(2), 167-183.

Combs, N. (2009). Testimonial Deficiencies and Evidentiary Uncertainties in International Criminal Trials, UCLA Journal of International Law and Foreign Affairs, 14(1), 235-273.

Coomaraswamy, R. (1998). Report of the Special Rapporteur on Violence Against Women, Its Causes and Consequences. UN doc, E/Cn.4/1998/54/Add.1, 4 February 1998.

Coomaraswamy, R. (2005). SV During Wartime. In D. Durham \& T. Gurd (Eds.), Listening to the Silences: Women and War (pp. 53-66). Boston: Martinus Nihoff Publishers. 
Copelon, R. (1994). Surfacing Gender: Reconceptualising Crimes against Women in Times of War. In A. Stiglmayer (Ed.), Mass Rape: The War Against Women in Bosnia-Herzegovina (pp. 197-219). Lincoln: University of Nebraska Press.

Cryer, R., Friman, H., Robinson, D. \& Wilmshurst, E. (2010). An Introduction to International Criminal Law and Procedure (2 ${ }^{\text {nd }}$ ed.). Cambridge: Cambridge University Press.

Davis, A. (1983). Rape, Racism and the Myth of the Black Rapist. New York: Random House.

Degni-Segui, R. (1994). Report on the Situation of Human Rights in Rwanda. UN doc, E/CN.4/1995/7, 28 June 1994.

Degni-Segui, R. (1996). Report on the Situation of Human Rights in Rwanda. UN Doc, E/CN.4/1996/68, 29 January 1996.

Dembour, M. \& Haslam, E. (2004). Silencing Hearings? Victim-Witnesses at War Crimes Trials. European Journal of International Law, 15, 151-177.

Dubinsky, K. (1993). Improper Advances: Rape and Heterosexual Conflict in Ontario, 1880-1929. USA: The University of Chicago Press.

Epstein, C. (2007). Great Divides: The Cultural, Cognitive and Social Bases of the Global Subordination of Women. American Sociological Review, 27, 1-22.

Estep, W. (1986). Renaissance and Reformation. USA: William B. Eerdmans Publishing Company.

Etchart, W. \& Baksh, R. (2005). Applying a Gender Lens to Armed Conflict, Violence and Conflict Transformation. In R. Baksh, I. Etchart, E. Onubogu \& T. Johnson (Eds.), Gender Mainstreaming in Conflict Transformation: Building Sustainable Peace (pp. 14-34). London: The Commonwealth Secretariat. 
Etcheson, C. (2005). After The Killing Fields: Lessons from the Cambodian Genocide. USA: Praeger Publishers.

Flanders, L. (2000). Rwanda: Women Speak. In A. Barstow (Ed.), War's Dirty Secret: Rape, Prostitution, and Other Crimes Against Women (pp. 95-100). Ohio: The Pilgrim Press.

Folnegovic-Smalc, V. (1994). Psychiatric Aspects of Rapes in the War Against the Republics of Croatia and Bosnia-Herzegovina. In A. Stiglmayer (Ed.), Mass Rape: The War against Women in Bosnia-Herzegovina (pp. 174-183). Lincoln: University of Nebraska Press.

Franke, K. (2006). Gendered Subjects of Transitional Justice. Columbia Journal of Gender and Law, 15(3), 813-828.

Fraser, N. (2007a). Re-framing Justice in a Globalising World. In T. Lovell (Ed.), (Mis)Recognition, Social Inequality and Social Justice: Nancy Fraser and Pierre Bourdieu (pp. 17-36). New York: Routledge.

Fraser, N. (2007b). Feminist Politics in the Age of Recognition: A Two-Dimensional Approach to Gender Justice. Studies in Social Justice, 1(1), 23-35.

Freeman, M. (1999). International Institutions and Gendered Justice. Journal of International Affairs, 52(2), 513-532.

Futamura, M. (2008). War Crimes Tribunals and Transitional Justice: The Tokyo Trial and the Nuremburg Legacy. London: Routledge.

GA. (1985). Declaration of Basic Principles of Justice for Victims of Crime and Abuse of Power. UN Doc, A/RES/40/34, 29 November 1985.

GA. (2011). Second Performance Reports for the Biennium 2010-2011 and Proposed Budgets for the Biennium 2012-2013 of the ICTR and the ICTY and Proposed 
Budget for the International Residual Mechanism for Criminal Tribunals for the biennium 2012-2013. UN doc, A/66/600, 9 December 2011.

Galina, N. (2010). The Impact of Transnational Advocacy Networks on the Prosecution of Rape and SV: The Case of the ICTR. International Science Review, 85(1-2), 3-27.

Gallimore, T. (2008). The Legacy of the ICTR and its Contributions to Reconciliation in Rwanda. New England Journal of International and Comparative Law, 14(2), 239-266.

Gardam, J. (2005). Women and Armed Conflict: The Responses of IHL. In D. Durham \& T. Gurd (Eds.), Listening to the Silences: Women and War (pp. 109-125). Boston: Martinus Nihoff Publishers.

Gillard, E. (2003). Reparation for Violations of IHL. Investor Responsibility Research Center Institute, 85, 539-593.

Goff, G. (2002). Analysis of Trends in SV Prosecutions in Indictments by the ICTR from November 1995 to November 2002. Retrieved from http://www.womensrightscoalition.org/advocacyDossiers/rwanda/rapeVictimss DeniedJustice/analysisoftrends_en.php. 10 July 2012.

Goldstein, J. (2001). War and Gender: How Gender Shapes the War System and Vice Versa. United Kingdom: Cambridge University Press.

Green, J., Copelon, R., Cotter, P. \& Stephens, B. (1994). Affecting the Rules for the Prosecution of Rape and Other Gender-Based Violence Before the ICTY: A Feminist Proposal and Critique. Hastings Womens Law Journal, 5(2), 171-241.

Grewal, K. (2010a). Crimes of War, Crimes of Peace: SV, 'Women's Rights as Human Rights' and the Criminal Justice System. Human Rights Human Wrongs: British Criminology Society Conference. Received from: 
http://sydney.edu.au/arts/sociology_social_policy/docs/Leicester_paper_6.7.10.p df. 21 October 2012.

Grewal, K. (2010b). Rape in Conflict, Rape in Peace: Questioning the Revolutionary Potential of International Criminal Justice for Women's Human Rights. Australian Feminist Law Journal, 33, 57-80.

Haddad, H. (2011). Mobilising the Will to Prosecute: Crimes of Rape at the Yugoslav and Rwandan Tribunals. Human Rights Review, 12, 109-132.

Haffajee, R. (2006). Prosecuting Crimes of Rape and SV at the ICTR: The Application of Joint Criminal Enterprise Theory. Harvard Journal of Law and Gender, 29, 201-221.

Haldemann, F. (2008). Another Kind of Justice: Transitional Justice as Recognition. Cornell International Law Journal, 41, 707-735.

Hall, A. (2012). Gaddafi 'Raped Countless Women During Years in Power', claims new documentary. Retrieved from: http://www.dailymail.co.uk/news/article2124491/Muammar-al-Gaddafi-raped-countless-women-years-powerLibya.html. 20 June 2012.

Hartman, C. \& Jackson, H. (1994). Rape and the Phenomenon of Transference. In J. Wilson \& J. Lindy (Eds.), Countertransference in the Treatment of PTSD (pp. 206-245). USA: Guildford Press.

Heidensohn, F. \& Gelsthorpe, L. (2007). Gender and Crime. In M. Maguire, R. Morgan \& R. Reiner (Eds.), The Oxford Handbook of Criminology $\left(4^{\text {th }}\right.$ ed.). Oxford: Oxford University Press.

Heineman, E. (2011). SV in Conflict Zones: From the Ancient World to the Era of Human Rights. USA: University of Pennsylvania Press. 
Heise, L. Pitgany, A. \& Germain, A. (1994). Violence Against Women: The Hidden Health Burden. World Bank Discussion Paper. Washington: World Bank.

Henry, N. (2009). Witness to Rape: The Limits and Potential of International War Crimes Trials for Victims of Wartime SV. The International Journal of Transitional Justice, 3, 114-134.

HRW. (2002). Back to the Brink: War Crimes by the Liberian Government and Rebels. Human Rights Watch, 14(4A), 0-23.

HRW. (2003). Struggling to Survive: Barriers to Justice for Rape Victims in Rwanda. Human Rights Watch, 16(10), 0-56.

HRW. (2004). Genocide, War Crimes, and Crimes against Humanity: Topical Digests of the Case Law of the ICTR and the ICTY. USA: HRW.

Huyse, L. (1995). Justice After Transition: On the Choices Successor Elites Make in Dealing with the Past. Law and Social Inquiry, 20(1), 51-78.

ICC. (2011). Rome Statute of the ICC. Retrieved from: http://www.icccpi.int/NR/rdonlyres/ADD16852-AEE9-4757-ABE79CDC7CF02886/283503/RomeStatutEng1.pdf. 6 June 2012.

ICLS. (n.d). Module 14: Victims and Witnesses: Support, Protection, Compensation and Participation. Retrieved from: https://www.google.co.nz/\#hl=en\&tbo=d\&sclient=psy$\underline{a b \& q}=$ special+measures+for+witnesses+and+victims+in+international+law\&oq =special+measures+for+witnesses+and+victims+in+international+law\&gs_l=hp 3...11013.177630.9.1777771.69.47.3.2.2.2.484.13027.2-

8j22j7.37.0.les\%3B..0.0...1c.1.rA5Zgny8wE\&pbx=1\&fp=1\&bpcl=38897761\&biw=1680\&bih=869\&bav=on.2, or.r gc.r pw.r cp.r qf.\&cad=b. 23 November 2012. 
ICRC. (2005). Convention (IV) Relative to the Protection of Civilian Persons in Time of War. Retrieved from: http://www.icrc.org/ihl.nsf/WebPrint/380FULL?OpenDocument. 15 July 2012.

ICRC. (2010). Treaties and Customary Law: Overview. Retrieved from: http://www.icrc.org/eng/war-and-law/treaties-customary-law/overview-treatiesand-customary-law.htm. August 252012.

ICTR. (2010a). Statute of the ICTR. Retrieved from: http://www.unictr.org/Portals/0/English\%5CLegal\%5CStatute\%5C2010.pdf. 6 June 2012.

ICTR. (2010b). Rules of Procedure and Evidence. Retrieved from: http://www.unictr.org/Portals/0/English/Legal/ROP/100209.pdf. 12 June 2012.

ICTR. (2012). Witness Support and Protection at ICTR. Retrieved from: http://www.unictr.org/AboutICTR/ICTRStructure/WitnessesVictimsSupportSect ionWVSS/tabid/106/Default.aspx. 7 November 2012.

ICTY. (2009a). Updated Statute of the ICTY. Retrieved from: http://www.icty.org/x/file/Legal\%20Library/Statute/statute sept09 en.pdf. 6 June 2012.

ICTY. (2009b). Rules of Procedure and Evidence. Retrieved from: http://www.icty.org/x/file/Legal\%20Library/Rules_procedure_evidence/IT032_r ev44_en.pdf. 6 June 2012.

ICTY. (2012). Landmark Cases. Retrieved from: http://www.icty.org/sid/10314. 31 July 2010.

ICWC. (1945). Charter of the International Military Tribunal. Retrieved from: http://www.uni-marburg.de/icwc/dateien/imtcenglish.pdf. 6 June 2012. 
IWPR. (2005). Foca Rape Case. Retrieved from: http://iwpr.net/report-news/foca-rapecase. 2 February 2012.

Jones, A. (2004). Gendercide and Gender. Nashville: Vanderbilt University Press.

Jordan, J. (2001). Worlds Apart? Women, Rape and the Reporting Process. British Journal of Criminology, 4(41), 679-706.

Jordan, J. (2011). Here We Go Round the Review-Go-Round: Rape Investigation and Prosecution - Are Things Getting Worse Not Better? Journal of Sexual Aggression, 17(3), 234-249.

Josse, E. (2010). 'They Came With Two Guns': The Consequences of SV for the Mental Health of Women in Armed Conflict. International Review of the Red Cross, 99 (877), 177-196.

Jupp, V. (2006). The Sage Dictionary of Social Science Research. London: Sage Publications Inc.

Kissi, E. (2006). Revolution and Genocide in Ethiopia and Cambodia. Oxford: Lexington Books.

KWPAT. (2011). Aid Urgently Needed for Refugees Fleeing Spreading Fighting and "Orders to Rape" in Kachin State. Retrieved from: http://www.ndburma.org/about-us/press-releases/707-aid-urgently-needed-for-refugeesfleeing-spreading-fighting-and-orders-to-rape-in-kachin-state.html. 20 June 2012.

Lambourne, W. (2009). Transitional Justice and Peace Building after Mass Violence. International Journal of Transitional Justice, 3, 28- 48.

Lauterpacht, H. (1996). The Development of International Law by the International Court. Cambridge: Cambridge University Press. 
Leatherman, J. (2011). SV and Armed Conflict. Cambridge: Polity Press.

Leavy, P. (2007). The Feminist Practice of Content Analysis. In S. Hesse-Biber \& P. Leavy (Eds.), Feminist Research Practice (pp. 223-248). United Kingdom: Sage Publications Inc.

Letherby, G. (2003). Feminist Research in Theory and Practice. Buckingham: Open University Press.

Levy, A. (1994). International Prosecution of Rape in Warfare: Non-discriminatory Recognition and Enforcement. UCLA Women's Law Journal, 4(255), 255-296.

MacKinnon, C. (1994). Rape, Genocide, and Women's Human Rights. In A. Stiglmayer (Ed.), Mass Rape: The War against Women in Bosnia-Herzegovina (pp. 183197). Lincoln: University of Nebraska Press.

MacKinnon, C. (2006). Are Women Human? And Other International Dialogues. USA: Harvard University Press.

Mahony, C. (2010). The Justice Sector Afterthought: Witness Protection in Africa. South Africa: Institute of Security Studies.

McCann, C. Kim, S. (2002). Feminist Theory Reader: Local and Global Perspectives. New York: Routlegde.

McDonald, E. \& Tinsley, Y. (2011). Rejecting 'One Size Fits All': Recommending a Range of Responses. In E. McDonald \& Y. Tinsley (Eds.), From "Real Rape" to Real Justice: Prosecuting Rape in New Zealand (pp. 377-438). Wellington: Victoria University Press.

McDougall, G. (1998). Systematic Rape, Sexual Slavery and Slavery-like Practices During Armed Conflict. UN doc, E/CN.4/Sub.2/1998/13, 22 June 1998. 
Mcgreal, C. (2001). A Pearl in Rwanda's Genocide Horror. Retrieved from: http:/www.guardian.co.uk/world/2001/dec/15/chrismcgreal. 10 March 2012.

McSherry, B. (1998). Constructing Lack of Consent. In P. Easteal (Ed.), Balancing the Scales: Rape, Law Reform and Australia Culture (pp. 26- 41). Sydney: The Federation Press.

Meir, E. (2004). Prosecuting SV Crimes During War and Conflict: New Possibilities for Progress. International Legal Theory, 10, 83-134.

Mertus, J. (2004). Shouting from the Bottom of the Well the Impact of International Trials for Wartime Rape on Women's Agency. International Feminist Journal of Politics, 6(1), 110-128.

Morash, M. (2005). Understanding Gender, Crime and Justice. USA: Sage Publications Inc.

Mukangendo, M. (2007). Caring for Children Born of Rape in Rwanda. In R. Carpenter (Ed.), Born of War: Protecting Children of SV Survivors in Conflict Zones (pp. 40-53). USA: Kumarian Press.

Mullins, C. (2009). He Would Kill Me With His Penis: Genocidal Rape in Rwanda as State Crime. Critical Criminology, 17(1), 15-33.

Nainar, V. (2012). Manual Litigation Strategies for SV in Africa. Retrieved from: http://www.iccnow.org/documents/VAW_Manual_27_Aug_2012.pdf. August 2012.

National Institute of Statistics of Rwanda. (2012). The Evolution of Poverty in Rwanda from 2000 to 2011: Results from Household Surveys (EICV). Rwanda: Department of International Development.

Neuffer, E. (2003). The Key to my Neighbour's House”: Seeking Justice in Bosnia and Rwanda. New York: Picador. 
Newbury, C. \& Baldwin, H. (2000). Aftermath: Women in Post-genocide Rwanda. Retrieved from: http://pdf.usaid.gov/pdf_docs/pnacj323.pdf. 12 July 2012.

Ni Aolain, F. (1997). Procedural Rules: The Effects of Evidential and Procedural Rules of the Regulation of SV in War. Albany Law Review, 60, 883-905.

Ni Aolain, F., Haynes, D. \& Cahn, N. (2011). Criminal Justice for Gendered Violence and Beyond. International Criminal Law Review, 11, 425-443.

Niarchos, C. (1995). Women, War, and Rape: Challenges Facing the ICTY. Human Rights Quarterly, 17(4), 649-90.

Nowrojee, B. (1996). Shattered Lives: SV During the Rwandan Genocide and its Aftermath. USA: HRW.

Nowrojee, B. (2004). We Can Do Better: Investigating and Prosecuting International Crimes of SV. Retrieved from: http://ictr-archive09.library.cornell.edu/ENGLISH/colloquium04/nowrojee.html. 15 September 2012.

Nowrojee, B. (2005). "Your Justice is too Slow": Will the ICTR Fail Rwanda's Rape Victims [Occasional Paper, 10]. Geneva: UN Research Institute for Social Development.

Nowrojee, B. (2007). "Your Justice is Too Slow": Will the ICTR Fail Rwanda's Rape Victims? In D. Pankhurst (Ed.), Gendered Peace: Women's Struggle for PostWar Justice and Reconciliation (pp. 107-137). New York: Routledge.

Obote-Odora, A. (2005). Rape and SV in International Law: ICTR Contribution. New England Journal of International and Comparative Law, 12, 135-159.

Office of the Prosecutor. (2009). Prosecutor Welcomes Convictions in the RUF Appeals Judgement. Retrieved from: 
http://www.scsl.org/LinkClick.aspx?fileticket=ITUGDfogLfQ\%3d\&tabid=196. 17 July 2012.

Oosterveld, V. (2005). Gender-Sensitive Justice and the ICTR: Lessons Learned for the ICC. New England Journal of Comparative Law, 12, 119-327.

Peskin, V. (2008). International Justice in Rwanda and the Balkans: Virtual Trials and the Struggle for State Cooperation. USA: Cambridge University Press.

Pillay, N. (2002). Statement by Judge Navanethem Pillay, President of the ICTR, to the UN's SC. Retrieved from: http://www.unictr.org/tabid/155/Default.aspx?id=1086. 15 September 2012.

Porter, E. (2007). Peacebuilding: Women in International Perspective. USA: Routledge.

Prunier, G. (1995). The Rwanda Crisis: History of a Genocide. UK: C. Hurst \& CO Publishers.

Rada, R. (1978). Clinical Aspects of Rape. New York: Grune and Stratton.

Ramazanoglu, C. \& Holland, J. (2002). Feminist Methodology: Challenges and Choices. London: Sage Publications Inc.

Reilly, N. (2007). Seeking Gender Justice in Post-Conflict Transitions: Towards a Transformative Women's Human Rights Approach. International Journal of Law in Context, 3(2), 155-172.

Sarantakos, S. (1998). Social Research ( $2^{\text {nd }}$ ed.). Hampshire: Macmillan Press.

SC. (1993). Resolution 827. UN Doc, S/1993/827, 25 May 1993.

SC. (1994a). Resolution 640. UN doc, S/1994/640, 31 May 1994. 
SC. (1994b). Resolution 955. UN doc, S/RES/955, 8 November 1994.

SC. (1994c). The Situation Concerning Rwanda. UN doc, S/PV.3453, 8 November 1994.

SC. (1994d). Report of the Secretary-General on the Situation in Rwanda. UN doc, S/1994/640, 31 May 1994.

SC. (1994e). Preliminary Report of the Independent Commission of Experts Established in Accordance with SC Resolution 935 (1994). UN doc, S/1994/1125, 4 October 1994.

SC. (1999). Fourth Annual Report. UN doc, S/1999/943, 7 September 1999.

SC. (2000a). Resolution 1325. UN doc, S/RES/1325, 31 October 2000.

SC. (2000b). Letter Dated 9 November from the President of the ICTR Addressed to the Secretary-General. UN doc, S/2000/1198, 15 December 2000.

SC. (2008). Resolution 1820. UN doc, S/Res/1820, 19 June 2008.

SC. (2009a).Resolution 1888. UN doc, S/RES/1888, 30 September 2009.

SC. (2009b). Resolution 1889. UN doc, S/RES/1889, 5 October 2009.

SC. (2010). Resolution 1960. UN doc, S/RES/1960, 16 December 2010.

Schabas, W. (2006). The UN ICTs: The Former Yugoslavia, Rwanda and Sierra Leone. United Kingdom: Cambridge University Press.

Schomburg, W., \& Peterson, I. (2007). Genuine Consent to SV under International Criminal Law. The American Journal of International Law, 101(1), 121-140. 
Scott, J. (1990). A Matter of Record: Documentary Sources in Social Research. Cambridge: Polity Press.

SCSL. (2000). SCSL Statute. Retrieved From: http://www.scsl.org/LinkClick.aspx?fileticket=uClnd1MJeEw\%3D\&. 6 June 2012.

Seelinger, K., Silverberg, H. \& Mejia, R. (2011). The Investigation and Prosecution of $S V . \quad$ Retrieved from: http://www.law.berkeley.edu/HRCweb/pdfs/SVA_IandP.pdf. 1 April 2012.

Seifert, R. (1994). War and Rape: A Preliminary Analysis. In A. Stiglmayer (Ed.), Mass Rape: The War against Women in Bosnia-Herzegovina (pp. 197-219). Lincoln: University of Nebraska Press.

Sellers, P. (2007). The Prosecution of SV in Conflict: The Importance of Human Rights as Means of Interpretation. Retrieved from: http://www.peacewomen.org/assets/file/Resources/Academic/paperprosecution sexualviolence.pdf. 3 April 2012.

Sharlach, L. (2000). Rape as Genocide: Bangladesh, the former Yugoslavia, and Rwanda. New Political Science, 22(1), 89-102.

Sharratt, S. (2011). Gender, Shame and SV: The Voices of Witnesses and Court Members at War Crimes Tribunals. England: Ashgate Publishing.

Sherlock, R. (2012). Syria Using Rape as Weapon against Opposition Women and Men. Retrieved from: http://www.telegraph.co.uk/news/worldnews/middleeast/syria/9296135/Syriausing-rape-as-weapon-against-opposition-women-and-men.html. 20 June 2012.

Siegel, L. (2011). Criminology (11 ${ }^{\text {th }}$ ed.). USA: Cengage Learning.

Sillah, A. (2009). Guinea Protest: Soldiers Raped Women in Streets, Killed Dozens of Protesters, Say Witnesses. Retrieved 
http://www.huffingtonpost.com/2009/09/29/guinea-protest-soldiers-

r_n_302633.html. 20 June 2012.

Smith, D. (2010). Former Congo Vice-President used 'rape as his method of war'. Retrieved from: http://www.guardian.co.uk/world/2010/nov/22/congo-vicepresident-trial-war-crimes. 19 March 2012.

Stanley, E. (2009). Torture, Truth and Justice: The Case of Timor-Leste. New York: Routledge.

Stover, E. (2005). The Witnesses: War Crimes and the Promise for Justice in the Hague. Philadelphia: University of Pennsylvania Press.

Survivors Fund. (2012). Submission to the Foreign Affairs Committee's Annual Inquiry into the FCO"s Human Rights Work in 2011. Retrieved from: http://survivorsfund.org.uk/wp-content/uploads/2012/05/SURF-Submission-to-FAC-23-May2012.pdf. 12 September 2012.

Temkin, J. \& Krahe, B. (2008). Sexual Assault and the Justice Gap: A Question of Attitude. Oxford: Hart Publishing.

Thornhill, R. \& Palmer, C. (2000). A Natural History of Rape: Biological Bases of Sexual Coercion. USA: Massachusetts Institute of Technology.

Triggs, S., Mossman, E., Jordan, J. \& Kingi, V. (2009). Responding to SV: Attrition in the New Zealand Criminal Justice System. Wellington: Ministry of Women's Affairs.

Trumbell, C. (2008). The Victims of Victim Participation in International Criminal Proceedings. Michigan Journal of International Law, 22(77), 777-826.

UN. (1996). The UN and Rwanda: 1993-1996. UN: New York. 
UN. (2005). Principles of International Law Recognized in the Charter of the Nürnberg Tribunal and in the Judgement of the Tribunal. Retrieved from: http://untreaty.un.org/ilc/texts/instruments/english/draft\%20articles/7_1_1950.p df. 15 August 2012.

UN. (2010). Review of the SV Elements of the Judgements of the ICTY, the ICTR, and the SCSL in the Light of SC Resolution 1820. Retrieved from: http://www.stoprapenow.org/uploads/advocacyresources/1284125586.pdf. 10 February 2011.

UN Women. (2011). Annual Report 2010-2011. Retrieved from: http://www.unwomen.org/wpcontent/uploads/2011/06/UNwomen AnnualReport 2010-2011 en.pdf. August 2012.

UN Women. (2012). Women, Poverty and Economics. Retrieved from: http://unwomennc.org.sg/gender_issues_datasheet_1.shtml. 29 November 2012.

University of Oslo. (1946). International Military Tribunal for the Far East Charter. Retrieved from: http://www.jus.uio.no/english/services/library/treaties/04/406/military-tribunal fareast.xml. 6 June 2012.

Valentino, B. (2004). Final Solutions: Mass Killing and Genocide in the Twentieth Century. New York: Cornwall University Press.

Vinjamuri, L. \& Snyder, J. (2004). Advocacy and Scholarship in the Study of Transitional Justice and International War Crimes Tribunals. Annual Review of Political Science, 7(1), 345-362.

Webber, A. \& Rone, J. (2003). Renewed Conflict in Northern Uganda. Human Rights Watch, 15(12A), 0-73.

Weiss, T. \& Daws, T. (2007). UN and Changing World Politics. Oxford: Oxford University Press. 
Wykes, M. \& Welsh, K. (2008). Violence, Gender and Justice. London: Sage Publications Inc.

Yeboah, D. (2008). Research Methodologies in Criminology. New York: Nova Science Publishers.

Yoshimi, Y. \& O’Brien, S. (2000). Comfort Women: Sexual Slavery in the Japanese Military During World War II. New York: Columbia University Press.

Young, M. (1990). Justice and the Politics of Difference. New Jersey: Princeton University Press.

Zacklin, R. (2004). The Failings of Ad Hoc Criminal Tribunals. Journal of International Criminal Justice, 2(2), 541-545.

Zolo, D. (2009). Victor's Justice: From Nuremburg to Baghdad. New York: University of Michigan. 


\section{List of Cases}

[Akayesu Appeal Judgement] - The Prosecutor vs. Jean-Paul Akayesu, Case No. ICTR96-4-A, Judgement, 1 June 2001.

[Akayesu Judgement] - The Prosecutor vs. Jean-Paul Akayesu, Case No. ICTR-96-4-T, Judgement, 2 September 1998.

[Bagilishema Indictment] - The Prosecutor vs. Ignace Bagilishema, Case No. ICTR-951A-I, Amended Indictment, 7 September 1999.

[Bagilishema Judgement] - The Prosecutor vs. Ignace Bagilishema, Case No. ICTR1995-1A-T, Judgement, 7 June 2001.

[Bagosora et al. Appeal Judgement] - The Prosecutor vs. Theoneste Bagosora, Gratien Kabiligi, Aloys Ntabakuze and Anatole Nsengiyumva, Case No. ICTR-98-41-A, Judgement, 14 September 2011.

[Bagosora et al. Judgement] - The Prosecutor vs. Theoneste Bagosora, Gratien Kabiligi, Aloys Ntabakuze and Anatole Nsengiyumva, Case No. ICTR-98-41-T, Judgement, 18 December 2008.

[Bikindi Judgement] - The Prosecutor vs. Simon Bikini, Case No. ICTR-01-72-T, Judgement, 2 December 2008.

[Bisengimana Judgement] - The Prosecutor vs. Paul Bisengimana, Case No. ICTR-0060-T, Judgement and Sentence, 13 April 2006.

[Furundzija Judgement] - The Prosecutor vs. Anto Furundzija, Case No. IT-95-17/1-T, Judgement, 10 December 1998.

[Gacumbitsi Appeal Judgement) - The Prosecutor vs. Sylvestre Gacumbitsi, Case No. ICTR-2001-64-A, Judgement, 7 July 2006. 
[Gacumbitsi Judgement] - The Prosecutor vs. Sylvestre Gacumbitsi, Case No. ICTR2001-64-T, Judgement, 17 June 2004.

[Kajelijeli Appeal Judgement] - The Prosecutor vs. Juvenal Kajelijeli, Case No. ICTR98-44A-A, Judgement, 23 May 2005.

[Kajelijeli Dissenting Opinion] - The Prosecutor vs. Juvenal Kajelijeli, Case No. ICTR98-44A-T, Dissenting Opinion of Judge Arlette Ramaroson, 1 December 2003.

[Kajelijeli Judgement] - The Prosecutor vs. Juvenal Kajelijeli, Case No. ICTR-199844A-T, Judgement and Sentence, 1 December 2003.

[Kamuhanda Judgement] - The Prosecutor vs. Jean de Dieu Kamuhanda, Case No. ICTR-1999-54A-T, Judgement and Sentence, 22 January 2004.

[Kayishema and Ruzindana] - The Prosecutor vs. Clement Kayishema and Obed Ruzindana, Case No. ICTR-1995-1-T, Judgement, 21 May 1999.

[Kunarac et al. Appeal Judgement] - The Prosecutor vs. Dragoljub Kunarac, Radomir Kovac and Zoran Vukovic, Case No. IT-96-23-A and IT-96-23/1, Judgement, 12 June 2002.

[Kunarac et al. Judgement] - The Prosecutor vs. Dragoljub Kunarac, Radomir Kovac and Zoran Vukovic, Case No. IT-96-23 and IT-96-23/1-T, Judgement, 8 November 2000.

[Mpambara Indictment] - The Prosecutor vs. Jean Mpambara, Case No. ICTR-01-65-I, Amended Indictment, 7 March 2005.

[Mpambara Judgement] - The Prosecutor vs. Jean Mpambara, Case No. ICTR-01-65-T, Judgement, 11 September 2006. 
[Mugenzi et al. Judgement] - The Prosecutor vs. Justin Mugenzi, Casmir Bizmungu, Jerome-Clement Bicamumpaka and Prosper Mugiraneza, Case No. ICTR-9950-T, Judgement, 30 September 2011.

[Muhimana Appeal Judgement] - The Prosecutor vs. Mikaeli Muhimana, Case No. ICTR-95-1B-A, Judgement, 21 May 2007.

[Muhimana Judgement] - The Prosecutor vs. Mikaeli Muhimana, Case No. ICTR- 951B-T, Judgement and Sentence, 28 April 2005.

[Musema Appeal Judgement] - The Prosecutor vs. Alfred Musema, Case No. ICTR-9613-A, Judgement, 16 November 2001.

[Musema Judgement] - The Prosecutor vs. Alfred Musema, Case No. ICTR-1996-13-T, Judgement, 27 January 2000.

[Ndindabahizi Judgement] - The Prosecutor vs. Emmanuel Ndindabahizi, Case No. ICTR-2001-71-I, Judgement and Sentence, 15 July 2004.

[Niyitegeka Appeal Judgement] - The Prosecutor vs. Eliezer Niyitegeka, Case No. ICTR-1996-14-A, Judgement, 9 July 2004.

[Niyitegeka Judgement] - The Prosecutor vs. Eliezer Niyitegeka, Case No. ICTR-199614-T, Judgement, 16 May 2003.

[Nsengimana Judgement] - The Prosecutor vs. Hormisdas Nsengimana, Case No. ICTR-01-69-T, Judgement, 17 November 2009.

[Ntakirutimana Judgement] - The Prosecutor vs. Elizaphan Ntakirutimana and Gerard Ntakirutimana, Case No. ICTR-1996-10 \& ICTR-1996-17-T, Judgement, 21 February 2003.

[Nzabirinda Judgement] - The Prosecutor vs. Joseph Nzabirinda, Case No. ICTR-200177-T, Judgement, 23 February 2007. 
[Renzaho Appeal Judgement] - The Prosecutor vs. Tharcisse Renzaho, Case No. ICTR97-31-A, Judgement, 1 April 2011.

[Renzaho Judgement] - The Prosecutor vs. Tharcisse Renzaho, Case No. ICTR-97-31T, Judgement and Sentence, 14 July 2009.

[Rugambarara Judgement] - The Prosecutor vs. Juvenal Rugambarara, Case No. ICTR60-00-T, Judgement, 16 November 2010.

[Rukondo Appeal Judgement] - The Prosecutor vs. Emmanual Rukondo, Case No. ICTR-01-70-A, Judgement, 20 October 2010.

[Rukondo Judgement] - The Prosecutor vs. Emmanual Rukondo, Case No. ICTR-01-70T, Judgement, 27 February 2009.

[Rutaganda Appeal Judgement] - The Prosecutor vs. Georges Rutaganda, Case No. ICTR-93-3-A, Judgement, 6 May 2004.

[Rutaganda Judgement] - The Prosecutor vs. Georges Rutaganda, Case No. ICTR-93-3T, Judgement, 6 December 1999.

[Semanza Appeal Judgement] - The Prosecutor vs. Laurent Semanza, Case No. ICTR1997-20-A, Judgement, 20 May 2005.

[Semanza Judgement] - The Prosecutor vs. Laurent Semanza, Case No. ICTR-1997-20T, Judgement, 15 May 2003.

[Serushago Judgement] - The Prosecutor vs. Omar Serushago, Case No. ICTR-98-39-T, Judgement, 5 February 1999. 


\section{Appendix I: Sexual Violence Cases in the International Criminal Tribunal for Rwanda}

The table below lists all 43 completed cases, in alphabetical order, as of March $28^{\text {th }}$, 2012. Of the 43 completed cases, 25 contain acts of SV committed against Rwandan women and girls. These cases (indicated by a *) formed the basis of this research. The table indicates how crimes of SV have been prosecuted in the ICTR.

Key:

\begin{tabular}{|c|l|}
\hline $\mathbf{G}$ & Genocide \\
\hline WC & War Crime \\
\hline CAH & Crimes against Humanity \\
& $\mathbf{R}=$ Rape \\
& $\mathbf{I}=$ Inhumane acts \\
& $\mathbf{P}=$ Persecution \\
& $\mathbf{T}=$ Torture \\
\hline
\end{tabular}

\begin{tabular}{|c|c|c|c|}
\hline Case & $\begin{array}{l}\text { Case Contains } \\
\text { References to } \\
\text { SV }\end{array}$ & $\begin{array}{c}\text { Outcome of } \\
\text { Judgement Relative } \\
\text { to SV Charges }\end{array}$ & $\begin{array}{l}\text { Outcome of } \\
\text { Appeal Relative } \\
\text { to SV Charges }\end{array}$ \\
\hline 1. Akayesu & $*$ & $\mathrm{G}+\mathrm{CAH}(\mathrm{R}, \mathrm{I})$ & $\mathrm{G}+\mathrm{CAH}(\mathrm{R}, \mathrm{I})$ \\
\hline 2. Bagilishema & $*$ & ACQUITTED & ACQUITTED \\
\hline 3. Bagaragaza & & & \\
\hline $\begin{array}{l}\text { 4. } \\
\text { Bagosora, } \\
\text { Kabiligi, } \\
\text { Ntabakuze and } \\
\text { Nsengiyumva }\end{array}$ & * & $\mathrm{G}+\mathrm{CAH}(\mathrm{R}, \mathrm{I}, \mathrm{P})+\mathrm{WC}$ & $\mathrm{G}+\mathrm{CAH}(\mathrm{R})+\mathrm{WC}$ \\
\hline 5. Bikindi & $*$ & $\begin{array}{l}\text { No charges laid } \\
\text { concerning SV, but } \\
\text { judgement contains } \\
\text { references to } S V\end{array}$ & \\
\hline 6. Bisengimana & $*$ & $\begin{array}{l}\text { Plea-bargain: Rape } \\
\text { charge subsequently } \\
\text { withdrawn }\end{array}$ & \\
\hline 7. Gaa & & & \\
\hline 8. Gacumbitsi & $*$ & $\mathrm{G}+\mathrm{CAH}(\mathrm{R})$ & $\mathrm{G}+\mathrm{CAH}(\mathrm{R})$ \\
\hline $\begin{array}{l}\text { 9. Imanishimwe, } \\
\text { Bagambiki and } \\
\text { Ntagerura }\end{array}$ & & & \\
\hline 10. Kajelijeli & $*$ & ACQUITTED & $\begin{array}{l}\text { SV charges not } \\
\text { appealed }\end{array}$ \\
\hline 11. Kalimanzira & & & \\
\hline 12. Kambanda & & & \\
\hline
\end{tabular}




\begin{tabular}{|c|c|c|c|}
\hline Case & $\begin{array}{c}\text { Case } \\
\text { Contains } \\
\text { References } \\
\text { to SV }\end{array}$ & $\begin{array}{l}\text { Outcome of Judgement } \\
\text { Relative to SV Charges }\end{array}$ & $\begin{array}{c}\text { Outcome of } \\
\text { Appeal } \\
\text { Relative to SV } \\
\text { Charges }\end{array}$ \\
\hline 13. Kamuhanda & $*$ & ACQUITTED & $\begin{array}{l}\text { SV charges } \\
\text { were not } \\
\text { appealed }\end{array}$ \\
\hline \multicolumn{4}{|l|}{ 14. Karera } \\
\hline $\begin{array}{l}\text { 15. Kayishema and } \\
\text { Ruzindana }\end{array}$ & * & $\begin{array}{l}\text { No charges laid concerning } \\
\text { SV, but judgement contains } \\
\text { references to SV }\end{array}$ & \\
\hline 16. Mpambara & * & $\begin{array}{l}\text { Indictment contained } \\
\text { references to SV, but these } \\
\text { were omitted from the } \\
\text { judgement }\end{array}$ & \\
\hline $\begin{array}{l}\text { 17. Mugenzi, Bizmungu, } \\
\text { Bicamumpaka and } \\
\text { Mugiraneza }\end{array}$ & * & ACQUITTED & $\begin{array}{l}\text { SV charges } \\
\text { were not } \\
\text { appealed }\end{array}$ \\
\hline 18. Muhimana & * & G+CAH (R) & G+CAH (R) \\
\hline \multicolumn{4}{|l|}{ 19. Munyakazi } \\
\hline 20. Musema & * & $\mathrm{G}+\mathrm{CAH}(\mathrm{R})$ & ACQUITTED \\
\hline $\begin{array}{l}\text { 21. Nahimana, } \\
\text { Barayagwiza and } \\
\text { Ngeze }\end{array}$ & * & CAH (P) & $\mathrm{CAH}(\mathrm{P})$ \\
\hline \multicolumn{4}{|l|}{ 22. Nchamihigo } \\
\hline 23. Ndindabahizi & * & Charges withdrawn & \\
\hline 24. Niyitegeka & * & $\mathrm{G}+\mathrm{CAH}(\mathrm{I})$ & ACQUITTED \\
\hline 25. Nsengimana & * & $\begin{array}{l}\text { No charges laid concerning } \\
\text { SV, but judgement contains } \\
\text { references to SV }\end{array}$ & \\
\hline \multicolumn{4}{|l|}{ 26. Nshogoza } \\
\hline $\begin{array}{l}\text { 27. Ntakirutimana, } \\
\text { Gerard and } \\
\text { Elizaphan }\end{array}$ & $*$ & $\begin{array}{l}\text { No charges laid concerning } \\
\text { SV, but judgement contains } \\
\text { references to SV }\end{array}$ & \\
\hline \multicolumn{4}{|l|}{ 28. Ntawukulilyayo } \\
\hline 29. Nzabirinda & $*$ & $\begin{array}{l}\text { Plea-bargain: Rape charge } \\
\text { subsequently withdrawn }\end{array}$ & \\
\hline 30. Renzaho & * & G+CAH (R) & ACQUITTED \\
\hline 31. Rugambarara & * & $\begin{array}{l}\text { Plea-bargain: Rape charge } \\
\text { subsequently withdrawn }\end{array}$ & \\
\hline \multicolumn{4}{|l|}{ 32. Ruggiu } \\
\hline 33. Rukondo & * & $\mathrm{G}$ & ACQUITTED \\
\hline 34. Rutaganda & * & $\mathrm{G}$ & $\mathrm{G}$ \\
\hline \multicolumn{4}{|l|}{ 35. Rutaganira } \\
\hline 36. Semanza & $*$ & $\mathrm{CAH}(\mathrm{R}, \mathrm{T})$ & $\begin{array}{l}\text { CAH }(\mathrm{R}, \mathrm{T}), \\
\text { WC }\end{array}$ \\
\hline \multicolumn{4}{|l|}{ 37. Seromba } \\
\hline 38. Serugendo & & & \\
\hline
\end{tabular}




\begin{tabular}{|l|c|c|c|}
\hline \multicolumn{1}{|c|}{ Case } & $\begin{array}{c}\text { Case } \\
\text { Contains } \\
\text { References } \\
\text { to SV }\end{array}$ & $\begin{array}{c}\text { Outcome of Judgement } \\
\text { Relative to SV Charges }\end{array}$ & $\begin{array}{c}\text { Outcome of } \\
\text { Appeal Relative } \\
\text { to SV Charges }\end{array}$ \\
\hline 39 Serushago & $*$ & $\begin{array}{l}\text { Plea-bargain: Rape charge } \\
\text { subsequently withdrawn }\end{array}$ & \\
\hline 40. Setako & & & \\
\hline 41. Simba & & & \\
\hline 42. Rwamakuba & & & \\
\hline 43. Zigiranyirazo & & & \\
\hline
\end{tabular}




\section{Appendix II: Sexual Violence Cases Recognised in the International Criminal Tribunal for Rwanda}

This Appendix identifies the 23 completed cases that contain references to SV committed against Rwandan women and girls. Although Ntakirutimana and Hormidas (identified in Appendix I) made references to SV, they were not included in this research. In these cases, SV was generally mentioned, with no specific connection to the defendant(s).

The 23 cases included in this research are arranged in five categories: (i) cases where successful convictions have been entered for SV crimes; (ii) cases where SV convictions have been overturned on appeal; (iii) cases where individuals have been acquitted of SV charges; (iv) cases where SV charges have been dropped or subsequently withdrawn; and (v) other relevant cases. However, at times, these categories do overlap. For instance, where cases are included under the successful convictions category, some SV allegations have successfully contributed to the guilty verdict, while other allegations relative to SV charges have resulted in an acquittal.

\section{Key points:}

- Cases involve individuals, as well as multi-accused.

- Those charged with SV mainly consist of national and local government leaders. However, media personnel [Nahimana et al.], civilians [Musema and Ruzindana], leaders of militia groups [Rutaganda, Serushago and Ngeze in Bagosora et al.] and a priest [Rukondo] also defended SV charges.

- In some cases, SV charges have been incorporated by an amendment of an original indictment [Akayesu, Bagilishema, Bagosora et al., Mpambara, Musema, Ndindabahizi and Niyitegeka].

- Category (iv) pertaining to cases where SV charges have been dropped, or subsequently withdrawn, was included to demonstrate how prosecutorial decisions affect how crimes of SV are recognised.

- This collation of case summaries is unique in the literature, particularly in terms of content and purpose. Due to word constraints, this research could not detail all instances of SV heard before the Chamber. Therefore, examples of SV have 
been specifically chosen to give a varied overview of the allegations heard before the ICTR. The cases were organised in five categories, which were developed after I carefully recorded SV findings for each case. For other (dated and limited) summaries see, however, UN (2009: 46-57) and Brouwer (2005: 493-498).

\section{Successful Sexual Violence Convictions}

\section{Akayesu}

Accused: Jean-Paul Akayesu

Overview: Akayesu, the former Bourgmestre of the Taba commune, was convicted of genocide and crimes against humanity (murder, extermination, torture, rape and inhumane acts).

SV evidence included numerous instances where Tutsi women and girls were subjected to SV and subsequently beaten and murdered in the Taba commune. The Chamber learned that while displaced civilians took refuge at the Bureau communal, Interahamwe and police regularly subjected women and girls to SV. One witness testified to having being taken from the cultural centre and into the forest, where she was raped by an Interahamwe armed with an axe and a long knife. She was later subjected to gang rape on the premises of the Bureau, with a group of approximately ten other girls and women, and raped on several other occasions. Another witness testified to having seen three women forced to undress, march and exercise naked by Interahamwe on Bureau premises. These acts were successfully charged as inhumane acts. Following these events, the women were then brutally raped, multiple times, by multiple assailants. One of these women, Alexia, was heavily pregnant, and subsequently went into premature labour whilst being raped. Later, the women were beaten to death with sticks.

The Chamber found that Akayesu had "specifically ordered, instigated, aided and abetted these acts of SV", by allowing such acts to take place on or near the Bureau premises, by being present during some acts, facilitating their commission through his words of encouragement, and because of his authority [Judgement: 67]. Akayesu was 
the first case in international criminal law to recognise rape as a constituent crime of genocide.

SV findings were upheld on appeal.

Sentence: Life imprisonment

\section{Bagosora et al.}

Accused: Theoneste Bagosora, Gratien Kabiligi, Aloys Ntabakuzu and Anatole Nsengiyumva

Overview: Bagosora was the directeur de cabinet of the Ministry of Defence; Kabiligi was the head of the Operation Bureau; Ntabakuzu was the commander of the elite Para Commando Battalion, and Nsengiyumva, was the commander of the Gsenyi Operational Sector. Kabiligi was acquitted on all charges, while the other three men were convicted of genocide, crimes against humanity (murder, persecution and inhumane acts) and war crimes. Bagosora was convicted of rape as a crime against humanity, as well as serious violations common to the Geneva Conventions (and Additional Protocol II). Bagosora and Nsengiyumva were also convicted of extermination as a crime against humanity.

All four men were charged with rape as a crime against humanity and rape as a war crime. However, Kabiligi, Ntabakuzu and Nsengiyumva were acquitted on these charges, due to the failure of the Prosecution to prove beyond reasonable doubt that they were responsible either directly, or as superiors, for such acts. Bagosora was found guilty of rape, inhumane acts and persecution as crimes against humanity, and of outrages upon personal dignity relative to various instances of SV. The Chamber ruled that he was the highest authority in the Ministry of Defence and exercised effective control over the Rwandan Army. Therefore, he bore responsibility for their actions.

The 'organised' killings involved the Rwandan Military who, at times, worked in conjunction with the Interahamwe and other militia. After the President was killed, roadblocks were set up throughout the city of Kigali. The Chamber confirmed that these 
roadblocks became notorious sites for slaughter and SV, including sexual mutilation. Women were taken from the site of a Kigali roadblock to a nearby house by soldiers, where they were repeatedly raped over several weeks. The Chamber ruled that this was "consistent with the pattern of SV, which occurred in connection with roadblocks" [Judgement: 379].

It was confirmed by the Chamber that SV was perpetrated at the Gikondo Parish. The testimony of a UN peacekeeper was considered to accurately reflect the nature of the crimes. He recalled that:

Pregnant women had their stomachs slashed open, foetuses on the floor. Even a foetus was smashed... I remember looking down, a woman had obviously tried to protect her baby. Somebody had rolled her off the baby. The baby was still alive and trying to feed on her breasts. She'd been... her clothes had been ripped off. The killing that was done was not done, in their opinion, to kill the people immediately; it had been done to kill them slowly. Women's breasts, women's vaginas had been cut with machetes. [Judgement: 243]

Furthermore, at the Saint Josephite Centre, many Tutsi women were forced to undress before being raped and murdered. These forced 'undressings' were successfully charged as inhumane acts. The Chamber also found Bagosora criminally responsible for the rape and murder of the Prime Minister, where it was confirmed that she had a bottle inserted into her vagina.

In addition to ruling that these acts constituted rape as a crime against humanity, the Chamber ruled that these acts constituted genocide. The Chamber stated that "considering the purpose of the roadblocks, the assailants intentionally killed Tutsis. The Chamber also finds that acts of rape, SV and mistreatment of the Tutsi's there caused serious bodily and mental harm" [Judgement: 542].

On appeal, Bagosora's conviction for inhumane acts as a crime against humanity (in relation to the sexual defilement of the Prime Minister) was overturned. However, all other SV findings were upheld.

Sentences: Kabiligi was immediately released. However, the other three men were each sentenced to life imprisonment for their convictions. On appeal, all three men had their 
sentences reduced: Bagosora to 35 years imprisonment, Nsengiyumva to 15 years imprisonment, and Ntabakuzu to 35 years imprisonment.

\section{Gacumbitsi}

Accused: Sylvestre Gacumbitsi

Overview: Gacumbitsi, the former Bourgmestre of the Rusomo commune, was convicted of genocide and crimes against humanity (extermination and rape).

The Chamber held that Gacumbitsi had publicly instigated the rape of Tutsi women and girls, after discovering that he had driven around with a megaphone inciting Hutu men to rape and sexually degrade Tutsi women and girls. During these 'announcements' he claimed that women who resisted rape should be killed in an atrocious manner and have sticks placed in their genitals. The rape of Witness TAQ and seven other Tutsi women, ranging in age from 12 years to an "old lady", were found to be a direct consequence of Gacumbitsi's instigation. One of these women was quartered, after a stick had been pushed into her genitals, subsequently causing her death.

In addition to establishing that these rapes constituted crimes against humanity, the Chamber found that they caused serious physical and mental harm to members of the Tutsi ethnic group, thus amounting to genocide. During trial, three accounts of rape were confirmed by the Chamber. However, Gacumbitsi was acquitted of these rapes upon the failure of the Prosecution to link him to these assaults.

SV findings were upheld on appeal.

Sentence: Life imprisonment

\section{Muhimana}

Accused: Mikaeli Muhimana

Overview: Muhimana, the former government conseiller of the Gishyita commune, was convicted of genocide and crimes against humanity (rape and murder). 
The Chamber found that Muhimana had personally raped seven women: six Tutsi women and one Hutu woman. Muhimana was also found to have abetted in the commission of rapes by others, including soldiers and Interahamwe, in three separate instances.

On one occasion he had taken two women back to his house and raped them. He then drove the women out of his house naked and invited Interahamwe to come and see "what naked Tutsi girls look like" [Judgement: 101]. Defence witnesses claimed that it was impossible in Rwandan culture to commit rape in the marital home. The Chamber did not accept this as evidence that these rapes had not occurred, and convicted Muhimana for these acts, ruling that they were consistent with the widespread and systematic attack against civilians.

The Chamber also learned that Muhimana had disembowelled a pregnant woman using a machete, cutting her open from her breast to her vagina. He then removed her baby which cried sometime before dying. The Chamber ruled that this act could not be classified as rape despite submissions from the Prosecution. Although the act involved sexual organs, it did not, in the Chamber's opinion, constitute a physical invasion of a sexual nature. These actions, however, were re-considered under the charge of murder.

With regards to genocide, it was discovered that Muhimana had raped a Hutu girl because he believed she was Tutsi. However, after he discovered that she was Hutu, he apologised to her. The Court ruled that during such attacks, Muhimana had often referred to the Tutsi identity of his victims, and therefore concluded that his actions demonstrated his intent to destroy the Tutsi.

On appeal, the Chamber's finding that Muhimana had raped two Tutsi women in his home was overturned. However, all other SV findings were upheld.

Sentence: Life imprisonment 


\section{Niyitegeka}

Accused: Eliezer Niyitegeka

Overview: Niyitegeka, the former Minister of Information, was convicted of genocide, conspiracy to commit genocide, direct and public incitement to commit genocide and crimes against humanity (murder, extermination and other inhumane acts). SV acts underpinned his conviction of inhumane acts and genocide. Niyitegeka was also charged with rape as a crime against humanity, although acquitted on this charge.

During trial it was alleged that Niyitegeka had raped a young girl. One witness recalled how the 13-15 year old girl was taken by Niyitegeka to his vehicle. Although this witness did not see the rape, he stated that Niyitegeka had raped the girl and "subsequently threw her in front of the vehicle and shot her with a big gun" [Judgement: 70]. While the Chamber ruled that the girl had been killed by Niyitegeka, there was insufficient evidence to rule that she had been raped, as the witness did not physically see the act.

The Chamber also ruled that Niyitegeka ordered Interahamwe to undress the body of a dead Tutsi woman. He then ordered them to fetch and sharpen a piece of wood and insert it into her vagina, an act which was successfully prosecuted as an inhumane act. The Chamber also considered this act when ascertaining Niyetegeka's intent to commit genocide, which helped confirm his intent "to destroy the Tutsi group" [Judgement: 96].

These findings were upheld on appeal.

Sentence: Life imprisonment

\section{Semanza}

Accused: Laurent Semanza

Overview: Semanza, the former Bourgmestre of the Bicumbi commune, was convicted of complicity to commit genocide and crimes against humanity (extermination, rape, 
torture and murder). On appeal, Semanza was also convicted of genocide and serious violations common to the Geneva Conventions (and Additional Protocol II).

Several SV allegations were made against Semanza during trial. One witness told the court that she had learnt that women and girls were raped during an attack on a Gikoro Protestant church, a location where refugees had fled as a safe haven. However, she was not an eye witness to these events; therefore the hearsay nature of the evidence was not enough to sustain a rape allegation.

The Chamber, however, did make SV findings concerning an incident where Semanza had directed a group of men to rape Tutsi women before killing them. The Chamber confirmed that Victim A was brutally raped, and her cousin, Victim B, was taken outside and killed by two other men. The Prosecution also alleged that Victim B was raped, however, insufficient evidence was provided to validate this charge. Nonetheless, the Chamber concluded that:

By encouraging a crowd to rape women because of their ethnicity, Semanza was encouraging the crowd to inflict severe physical or mental pain or suffering for discriminatory purposes. Therefore, he was instigating not only rape, but rape for a discriminatory purpose, which legally constitutes torture. [Judgement: 147]

Sentence: Semanza was sentenced to 25 years imprisonment, which was increased to 35 years on appeal.

\section{Sexual Violence Convictions Overturned on Appeal}

\section{Musema}

Accused: Alfred Musema

Overview: Musema, a director of a tea factory, was convicted of genocide and crimes against humanity (extermination and rape).

During trial, the Chamber heard how Musema had claimed that "those who wanted to have fun could rape the women and girls of the Tutsi without fearing any consequences" [Judgement: 125]. The rapes of many women were recounted in court, some of which Musema had committed personally. 
The Chamber confirmed that Musema had raped a Tutsi woman named Nyiramusugi. Four other men had held her down while Musema undressed her. Before raping Nyiramusugi, he shouted "today the pride of the Tutsi ends" [Judgement: 235]. When Musema left the scene the other men took turns raping Nyiramusugi. The Chamber ruled that Musema's actions were consistent with the pattern of widespread and systematic violence perpetrated against the civilian population. Thus he was found criminally responsible for rape as a crime against humanity. In addition, the Chamber ruled that SV amounted to genocide, as these acts specifically contributed to the destruction of the Tutsi [Judgement: 255].

During trial, the Chamber also learned that Musema had ordered another Tutsi woman, Annunciata, to be raped by his subordinates, and her breast to be cut off and fed to her son. However, the Chamber ruled that there was inconclusive evidence to confirm that these acts had been carried out.

On appeal, Musema's conviction for rape as a crime against humanity, and subsequently genocide, was overturned in light of additional evidence that proved that there was reasonable doubt as to whether Nyiramusugi was raped.

Sentence: Life imprisonment

\section{Renzaho}

Accused: Tharcisse Renzaho

Overview: Renzaho, the former prefect of the Kigali-Ville Prefecture and colonel of the Rwandan Army, was convicted of genocide, crimes against humanity (murder and rape) and serious violations common to the Geneva Conventions (and Additional Protocol II).

The Prosecution alleged that, throughout the Rugenge sector, Tutsi women and girls were raped by persons under Renzaho's control, including members of the Rwandan Army and the Civil Defence Force, Interahamwe, civilian militias, urban police and administrative officials. In support of these allegations, Witness AWO testified that at a nearby orphanage refuge, Renzaho had arrived with Interahamwe dressed as soldiers 
and told the refugees to leave due to over-crowding. After her return home, for a period of seven to eight weeks, AWO was raped on a daily basis. She was raped by Interahamwe, policemen and soldiers. She told the court that Renzaho said she could not be killed as she "was food for the militia men" [Judgement: 184]. Another witness, AWN, testified that she and her sister were brought to the Rugene sector office. Here, Renzaho stated that it was "time to show the Tutsi women that the Hutus are strong and can do whatever they wanted to do with them" [Judgement: 187]. For the next three to four weeks, AWN and her sister were repeatedly raped by officials and Interahamwe.

The Chamber concluded that these rapes formed part of a widespread and systematic attack against the Tutsi, which caused serious mental and bodily harm, thus amounting to genocide. These acts were also successfully prosecuted as crimes against humanity (rape) and war crimes (outrages upon personal dignity).

On appeal, the convictions successfully entered for rape as genocide, as a crime against humanity and as a war crime were reversed, due to the indictment being rendered defective. The Appeals Chamber concluded that the Prosecution had failed to sufficiently plead that Renzaho had reason to know that rapes were committed in the indictment, which would have allowed him to better prepare for court. More specifically, Renzaho had not received clear or consistent notice of the "conduct by which he had reason to know of the rapes" [Appeal Judgement: 38].

Sentence: Life imprisonment

\section{Rukondo}

Accused: Emmanual Rukondo

Overview: Rukondo was a military chaplain in the Rwandan Army. He was convicted of genocide and crimes against humanity (murder and extermination).

The Chamber confirmed that Rukondo had sexually assaulted a young Tutsi woman, Witness CHH. It was found that he locked her in a room and forced her onto the bed. He then forced himself on top of her and tried to spread her legs so he could have sex 
with her, to which she resisted. He then gave up, but proceeded to caress and kiss her against her will, rubbing his body on top of her body until he ejaculated.

The Chamber ruled that Witness $\mathrm{CHH}$ had "suffered serious mental harm as a consequence of Rukondo's actions" [Judgement: 118]. After considering the wider context of the mass violence committed in the Gitarama prefecture, the Chamber concluded that Rukondo's sexual assault constituted genocide.

On appeal, however, the Chamber concluded that "the general context of mass violence cited by the Trial Chamber is insufficient to justify a finding of genocidal intent" [Appeal Judgement Summary: 8]. Thus the finding of genocide, with respect to this particular incident, was overturned.

Sentence: Rukondo was sentenced to 25 years imprisonment, which was decreased to 23 years on appeal.

\section{Acquittals Concerning Sexual Violence}

\section{Bagilishema}

Accused: Ignace Bagilishema

Overview: Bagilishema, the former Bourgmestre of the Mabanza commune, was charged with genocide, complicity in genocide, crimes against humanity (murder, extermination and other inhumane acts) and serious violations common to the Geneva Conventions (and Additional Protocol II). He was acquitted on all charges, the decisions of which were upheld on appeal.

During trial very little was said about SV, except that Bagilishema had reason to know that outrages upon personal dignity, including humiliating and degrading treatment, such as rape, were being committed by his subordinates against Tutsi women in the Mabanza commune.

Sentence: Bagilishema was immediately released following his acquittal. 


\section{Kajelijeli}

Accused: Juvenal Kajelijeli

Overview: Kajelijeli, the former Bourgmestre of the Mukingo commune, was convicted of genocide and extermination as crimes against humanity. With regard to SV, he was indicted for rape and inhumane acts as crimes against humanity, but acquitted on both charges.

The Chamber found that many rapes had occurred within the Mukingo commune. One Tutsi victim recalled how three Interahamwe members had taken turns holding her down, while each of the men raped her. A fourth member then came over and threw a cigarette stub on her vagina and kicked her, which caused her to faint. Other incidents confirmed by the Chamber included the rape of a Tutsi woman named Joyce, and another woman named Nyiramburanga. Joyce was raped by Interahamwe, who then pierced her vagina with a spear, resulting in her death. Nyiramburanga was raped by a member of the Interahamwe, who then cut off her breast and licked it.

The Chamber also heard the testimony of Witness GDO, who relayed evidence of the rape and murder of her 15 year old handicapped daughter. Both the witness and her daughter were hiding in a forest, when she overheard the Accused instruct the Interahamwe to rape and murder the women hiding in the bushes. Soon thereafter, they found her daughter, threw her on the ground, stripped her naked and raped her. The witness also testified to having being beaten and stripped naked herself, causing her to lose consciousness. When she regained consciousness, she discovered her murdered daughter, whose body was left positioned with her mouth open and her legs spread apart. A baby was screaming next to her dead body, as it lay in a pool of blood which came from her daughter's vagina.

Despite having confirmed that these rapes, along with others, had occurred throughout the Mukingo Commune, the Chamber ruled that the Prosecution had failed to establish beyond reasonable doubt that Kajelijeli "had either planned, instigated, ordered, committed or otherwise aided and abetted in the planning, preparation or execution of" 
them [Judgement: 200]. These decisions were not contested by the Prosecution in the Appeals Chamber.

Sentence: Kajelijeli was sentenced to life imprisonment, which was later reduced to 45 years on appeal.

\section{Mugenzi et al.}

Accused: Justin Mugenzi, Casmir Bizmungu, Jerome-Clement Bicamumpaka and Prosper Mugiraneza.

Overview: Mugenzi was the Minister of Commerce in the transitional government; Bizmungu was the Minister of Health; Bicamumpaka was the Minister of Foreign Affairs; and, Mugiraneza was the Minister of Civil Service. Bizmungu and Bicamumpaka were acquitted on all charges, while Mugiraneza and Mugenzi were found guilty of conspiracy to commit genocide and direct and public incitement to commit genocide.

The indictment included a range of SV charges made against the four men, including rape as a crime against humanity and as a serious violation common to the Geneva Conventions (and Additional Protocol II). However, the Chamber concluded that there was insufficient evidence against Bicamumpaka and Mugiraneza to prove beyond a reasonable doubt that they were guilty of rape. Consequently, all men were acquitted mid-trial on these charges.

Sentence: Mugenzi and Mugiraneza were sentenced to 30 years imprisonment, whereas Bicamumpaka and Bizmungu were immediately released following their acquittal.

\section{Kamuhanda}

Accused: Jean de Dieu Kamuhanda

Overview: Kamuhanda, the former Minister of Higher Education and Scientific Studies, was convicted of genocide and extermination as a crime against humanity. With regard to $\mathrm{SV}$, he was indicted for rape as a crime against humanity, but acquitted. 
The evidence in support of SV referred to the attack on the Gikomero Compound. One witness, whom the Chamber regarded as credible, recalled how she saw girls being selected, and then taken from the Compound in a vehicle. After the events, the witness learned that the girls had been taken to a camp, where all but one were raped and murdered. Another witness, also deemed credible, recalled seeing women being taken away to be raped by their attackers. She did not personally witness the rapes, but had been told about them by her daughter and two of the victims. The Chamber ruled that the 'hearsay' nature of the evidence was not enough to sustain a rape charge against Kamuhanda.

Sentence: Life imprisonment

\section{Withdrawal of Sexual Violence Charges}

\section{Bisengimana}

Accused: Paul Bisengimana

Overview: Bisengimana was the former Bourgmestre of the Gikoro commune. An early indictment contained a charge of rape as a crime against humanity. However, this charge was later withdrawn after Bisengimana entered into a plea bargain, and plead guilty to crimes against humanity (murder and extermination).

Sentence: 15 years imprisonment

\section{Ndindabahizi}

Accused: Emmanuel Ndindabahizi

Overview: Ndindabahizi, the former Minister of Finance, was convicted of genocide and crimes against humanity (murder and extermination). Ndindabahizi was initially charged with rape as a crime against humanity. However, the Prosecution withdrew this charge before it went to trial.

Sentence: Life imprisonment 


\section{Nzabirinda}

Accused: Joseph Nzabirinda

Overview: Nzabirinda was the former Youth Organiser of the Ngoma commune. He was an ICTR investigator until it was discovered that he had participated in the genocide. He had produced forged documents omitting his real name in order to secure his position. An early indictment against Nzabirinda charged him of rape as a crime against humanity. However, this charge was later withdrawn after Nzabirinda entered into a plea bargain, and plead guilty to murder as a crime against humanity.

Sentence: Seven years imprisonment

\section{Rugambarara}

Accused: Juvenal Rugambarara

Overview: Rugambarara, the former Bourgmestre of the Bicumbi commune, was originally indicted for genocide, conspiracy to commit genocide, direct and public incitement to commit genocide, crimes against humanity (extermination, torture and rape) and serious violations common to the Geneva Conventions (and Additional Protocol II). However, the Prosecutor later amended the indictment to include only one charge, extermination as a crime against humanity, to which Rugambarara plead guilty.

Sentence: 11 years imprisonment

\section{Serushago}

Accused: Omar Serushago

Overview: Serushago, one of five leaders of the Interahamwe in Gisenyi, was initially indicted for genocide and crimes against humanity (murder, extermination, torture and rape). 
With regard to SV, the indictment alleged that soldiers, militia and gendarmes "raped and sexually assaulted or committed crimes of a sexual nature against Tutsi women and girls, sometimes after having kidnapped them first" [Judgement: 11]. On one occasion, it was alleged that Serushago witnessed the rape of a Tutsi woman being perpetrated by one his subordinates, yet failed to prevent or stop it.

Serushago plead guilty to all counts, except the charge of rape as a crime against humanity. The Prosecution later withdrew this charge.

Sentence: 15 years imprisonment

\section{Other Relevant Cases}

\section{Bikindi}

Accused: Simon Bikindi

Overview: Bikindi, who formerly worked for the Ministry of Youth, was convicted of incitement to commit genocide. While no charges were laid by the Prosecution concerning SV, the indictment noted that widespread and systematic SV was committed against Tutsi women in the Gisenyi prefecture, and Bikini knew, or had reason to know, that these acts were being committed by his subordinates.

In support of these allegations, the Prosecution noted that a woman named Ancilla was taken away by two Interahamwe, under the orders of Bikindi, and raped and murdered. The Prosecution alleged that "Bikindi was aware or ought to have been aware of the acts of rape and SV committed against Ancilla" [Judgement: 85]. While the Chamber had no doubt that Ancilla was murdered during the genocide, it had serious reservations concerning the credibility of Witness AJZ and AJY who testified in support of this alleged crime. The Chamber later concluded that their evidence did not prove beyond reasonable doubt that Bikindi "had participated in the killing or rape of Ancilla" [Judgement: 87].

Sentence: 15 years imprisonment 


\section{Kayishema and Ruzindana}

Accused: Clement Kayishema and Obed Ruzindana

Overview: Kayishema was the former Prefect of Kibuye, whereas Ruzindana was a local business man. Both defendants were found guilty of genocide: Kayishema on four counts, Ruzindana on one.

No SV charges were made against either of the men. However, the Chamber made several findings concerning SV against civilians in its deliberations, although such acts were not linked to the defendants. Some witnesses recounted having seen Tutsi women being raped at roadblocks in Kibuye. One witness also relayed how his wife was gang raped by Interahamwe before their children. In its legal findings, the Chamber mentioned these incidents, and commented on many witnesses who were forced to watch their loved ones being raped, brutalised and killed in front of them.

Sentence: Kayishema was sentenced to life imprisonment, and Ruzindana was sentenced to 25 years imprisonment.

\section{Mpambara}

Accused: Jean Mpambara

Overview: Mpambara, the former Bourgmestre of the Rukara Commune, was charged with genocide (or complicity) and extermination as a crime against humanity, but acquitted on all charges. While no charges were laid by the Prosecution concerning SV, the indictment stated that Tutsi females were subjected to brutal acts of SV, as well as a Hutu woman who was married to a Tutsi, and carrying his child. The indictment alleged that Mpambara "should have known that SV was occurring, and that the perpetrators were his subordinates, subject to his authority and control, or acting under his orders or those of the other participants in the joint criminal enterprise" [Indictment: 6]. However, SV instances were omitted from the trial judgement.

Sentence: Mpambara was immediately released following his acquittal. 


\section{Nahimana et al.}

Accused: Ferdinand Nahimana, Jean-Bosco Barayagwiza and Hassan Ngeze

Overview: Nahimana was one of the founding members of Radio Television Libre des Mille Collines (RTLM); Barayagwiza was a founding of member of the comite d'initiative for RTLM; and, Ngeze was a Rwandan journalist, founding member of Movement for Defence and a militia leader in the Gisenyi Prefecture. All men were convicted of genocide, conspiracy to commit genocide, incitement to commit genocide and crimes against humanity (persecution and extermination). On appeal, all were acquitted of conspiracy to commit genocide, and all genocide charges relating to their involvement with RTLM and Kangura respectively. The conviction of extermination as a crime against humanity was also reversed, as well as Barayagwiza's conviction for incitement to commit genocide.

Dubbed the "Media Case", the three defendants were connected to the RTLM radio broadcasts or the Kangura publications which vehemently targeted the Tutsi. The Chamber learned that Tutsi women and girls were frequently raped and subject to other SV acts before being killed. One witness, for example, revealed that his pregnant sister was sexually violated with an umbrella, subsequently causing her death. The Chamber ruled that RTLM broadcasts and Kangura publications targeted Tutsi women for persecution, stating that:

The portrayal of the Tutsi women as a femme fatale and the message that Tutsi women were seductive agents of the enemy was conveyed repeatedly by RTLM and Kangura...By defining Tutsi women in this way, RTLM and Kangura articulated a framework that made the sexual attack of the Tutsi women a foreseeable consequence. [Judgement: 353]

However, no charges specifically pertaining to SV were laid against the men. Instead, SV findings were mentioned in the Chamber's legal deliberations regarding Nahimana's conviction for persecution as a crime against humanity.

Sentence: On appeal, Nahimana and Ngeze's sentences of life imprisonment were reduced to 30 years imprisonment. In addition, Barayagwiza's sentence was reduced from 35 years to 32 years imprisonment. 


\section{Rutaganda}

Accused: Georges Rutaganda

Overview: Rutaganda was a former youth militia leader who was convicted of genocide and crimes against humanity (murder and extermination).

Although no SV charges were laid, the Chamber did making findings concerning SV. It discovered that refugees fleeing the Amarhoro Stadium were stopped by soldiers. The women and children were separated from the group and raped by Interahamwe. When the remaining refugees arrived at Nyanza, they were surrounded by Interahamwe and soldiers, who then proceeded to separate the Hutu from the Tutsi. The Tutsi were then attacked and slaughtered. Those women and girls who had survived the previous attacks were put aside and raped before being murdered. The clothing of these women and girls was taken from their bodies. The Chamber ruled that Rutaganda directed and participated in attacks against the Tutsi, where Tutsi women and girls were raped. These findings were upheld on appeal.

Sentence: Life imprisonment 